\title{
Pre-hospitale Beta-blockers in ST-elevation acute myocardial infarction = Pre-hospitale beta-blocker toediening in acuut myocard infarct.
}

Citation for published version (APA):

Roolvink, V. (2018). Pre-hospitale Beta-blockers in ST-elevation acute myocardial infarction = Prehospitale beta-blocker toediening in acuut myocard infarct. [Doctoral Thesis, Maastricht University]. Maastricht University. https://doi.org/10.26481/dis.20180629vr

Document status and date:

Published: 01/01/2018

DOI:

10.26481/dis.20180629vr

Document Version:

Publisher's PDF, also known as Version of record

Please check the document version of this publication:

- A submitted manuscript is the version of the article upon submission and before peer-review. There can be important differences between the submitted version and the official published version of record. People interested in the research are advised to contact the author for the final version of the publication, or visit the DOI to the publisher's website.

- The final author version and the galley proof are versions of the publication after peer review.

- The final published version features the final layout of the paper including the volume, issue and page numbers.

Link to publication

\footnotetext{
General rights rights.

- You may freely distribute the URL identifying the publication in the public portal. please follow below link for the End User Agreement:

www.umlib.nl/taverne-license

Take down policy

If you believe that this document breaches copyright please contact us at:

repository@maastrichtuniversity.nl

providing details and we will investigate your claim.
}

Copyright and moral rights for the publications made accessible in the public portal are retained by the authors and/or other copyright owners and it is a condition of accessing publications that users recognise and abide by the legal requirements associated with these

- Users may download and print one copy of any publication from the public portal for the purpose of private study or research.

- You may not further distribute the material or use it for any profit-making activity or commercial gain

If the publication is distributed under the terms of Article 25fa of the Dutch Copyright Act, indicated by the "Taverne" license above, 


\section{Pre-hospital Beta-Blockers in ST-elevation acute myocardial Infarction.}

Vincent Roolvink 
Layout and printed by: Optima Grafische Communicatie (www.ogc.nl) ISBN: 978-94-6361-103-9 
Pre-hospitale Beta-blockers in ST-elevation acute myocardial Infarction.

Pre-hospitale beta-blocker toediening in acuut myocard infarct.

\section{Proefschrift}

Ter verkrijging van de graad van doctor aan de Universiteit Maastricht op gezag van de rector magnificus

Prof. Dr. Rianne M. Letschert

en volgens besluit van het College voor decanen.

De openbare verdediging zal plaatsvinden op

Vrijdag 29 juni 2018 om 14:00 uur

Vincent Roolvink

Geboren te Enschede op 9 januari 1977 
Promotor:

Copromotor:

Beoordelingscommissie:
Prof. Dr. A.W.J van 't Hof

Dr. J.P. Ottervanger, Isala ziekenhuis, Zwolle

Prof. Dr. H.P. Brunner La Rocca, voorzitter

Prof. Dr. N. van Royen, Radboud UMC, Nijmegen

Prof. Dr. F. Zijlstra, Erasmus MC, Rotterdam

Prof. Dr. J.C.A. Hoorntje 


\section{Content}

Chapter 1 Introduction and outline of the thesis

Chapter 2 The sooner, the better: early beta-blocker administration in patients with

ST-elevation myocardial infarction. Crit Care Med. 2013 ;41(6):1566-8.

Chapter 3 Rationale and Design of a Double-blind, Multicenter, Randomized,

Placebo controlled Clinical trial of Early Administration of Intravenous Beta-blockers in Patients with ST-elevation Myocardial Infarction before Primary PCI.: EARLY Beta-blocker Administration before primary $\mathrm{PCI}$ in patients with ST-elevation Myocardial Infarction (EARLY-BAMI) trial. Am Heart J. 2014;168(5):661-6.

Chapter 4 Effects of chronic beta-blocker treatment on admission haemodynamics in STEMI patients treated with Primary Angioplasty. European Heart Journal: Acute Cardiovascular Care. 2017. Epub ahead of print.

Chapter 5 Early Intravenous Beta-Blockers in Patients With ST-Segment Elevation Myocardial Infarction Before Primary Percutaneous Coronary Intervention. EARLY-BAMI Investigators. J Am Coll Cardiol. 2016 Jun 14;67(23):2705-15

Chapter 6 One-year clinical outcome of early administration of intravenous betablockers in patients with ST-segment elevation myocardial infarction before primary percutaneous coronary intervention. One-year results from the EARLY-BAMI trial. Eurointervention 2017, accepted.

Chapter 7 Early intravenous beta-blockers in patients undergoing primary percutaneous coronary intervention for ST-segment elevation myocardial infarction. A patient-pooled meta-analysis of randomized clinical trials. Eurointervention, 2018, submitted

Chapter 8 Summery, conclusions and future perspectives 

Introduction
and outline of the thesis.

1 



\section{STEMI.}

ST-elevation myocardial infarction (STEMI) is still an important cause of mortality and morbidity. $(1,2)$ STEMI is mostly caused by an acute occlusion of a major coronary artery, usually due to disrupter of an atherosclerotic plaque with subsequent formation of an occluding thrombus. (3)

Rapid restoration of blood flow to the ischemic myocardial tissue is the most important treatment.

Lysis of the thrombus with medication, so called thrombolytics, has been the treatment of choice. But since the early ' 90 primary percutaneous coronary intervention (PCI) has become the preferred strategy for reperfusion in the treatment of STEMI when feasible and performed in a timely matter. Primary PCI has been shown to be superior to fibrinolytic therapy. (4-6)

Despite advances in the care for patients with ST-segment elevation myocardial infarction (STEMI), mortality in these patients remains relative high, especially in an all-comer population. (7) Although early diagnosis and treatment have improved outcome of these patients, additional interventions early after onset of ischemia might further enhance survival. Moreover, reduction of infarct size may decrease late-onset heart failure or occurrence of fatal arrhythmias.

\section{INFARCT SIZE}

Tissue changes that occur in the myocardium during a myocardial infarction are related to the extent to which the cells have been deprived of oxygen. Total deprivation results in an area of infarction, in which the cells die and the tissue becomes necrotic. Necrosis is evident within 5 to 6 hours after a coronary occlusion. (8) In response to this necrosis the body increases its production of leukocytes, which aid in removal of the dead cells. As collateral circulation enlarges, it brings fibroblasts, which form a connective tissue scar within the area of infarction.

The extent of the necrotic tissue is determined by the location and duration of the coronary occlusion, but also by the myocardial oxygen demand at the time of the infarction. The oxygen demand of the heart is higher when the heartrate increases. So, lowering the heartrate in an ischemic situation could be beneficial in preserving myocardial tissue. 


\section{PRE-HOSPITAL TREATMENT OF STEMI}

In most patients with STEMI, the diagnosis is made by ambulance nurses, particularly by characteristic electrocardiographic abnormalities. After the diagnosis is clear, pre-hospital medical treatment is started by the ambulance nurses, before the patient is transported to a hospital for primary $\mathrm{PCI}$. It is without doubt, that the ambulance has a key role in the treatment of STEMI. (figure 1)

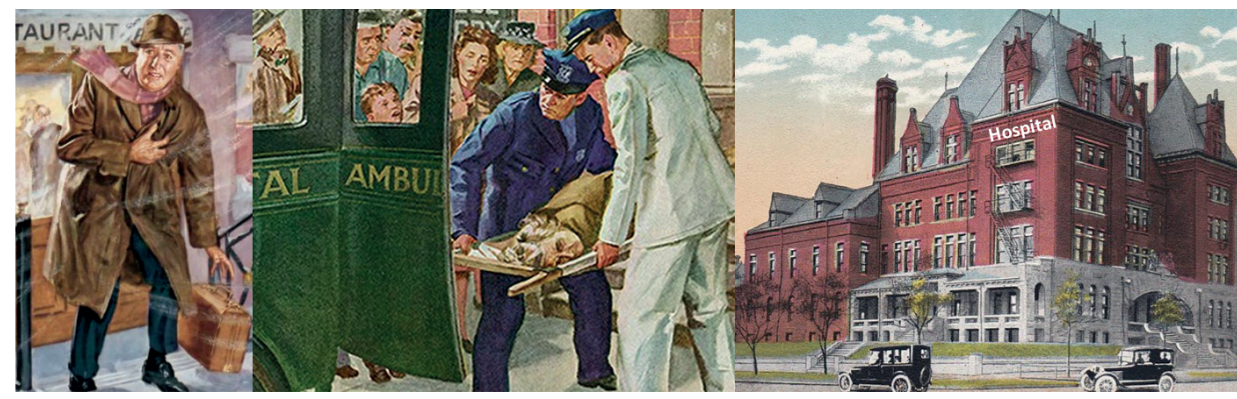

Chest Pain

1. Diagnosis

2. Pre-hospital treatment:

- Aspirin, heparin

- Beta-blokkers?

\section{Transportation to hospital}

Figure 1 - Initial treatment of ST elevation Myocardial Infarction.

Evidence and guidelines on aspirin and heparin has been shown to reduce mortality in ACS by $23 \%$. According to the European Society of Cardiology (ESC) STEMI guidelines, Aspirin should be given to all patients with acute STEMI as soon as possible after the diagnosis. $(9,10)$ Aspirin should be started at a dose of $150-325 \mathrm{mg}$ in a chewable form, or i.v. administration at a dose of $250 \mathrm{mg}$. A lower dose $(100 \mathrm{mg})$ is orally daily thereafter for life. Unfractionated heparin (UFH) is the standard antithrombotic therapy during PCI in STEMI. Unfractionated heparin is given as an intravenous bolus at a usual starting dose of $100 \mathrm{U} / \mathrm{kg}$ weight.

Ticagrelor or Clopidogrel should be given early to all patients with STEMI referred for primary $\mathrm{PCl}$, which has been demonstrated to achieve a more rapid and stronger inhibition of platelet aggregation.

It has been questioned, whether early beta-blocker treatment is also beneficial in patients with STEMI. 


\section{BETA-BLOCKERS.}

Beta blockers are competitive antagonists that block the receptor sites for the endogenous epinephrine (adrenaline) and norepinephrine (noradrenaline) on adrenergic beta receptors, of the sympathetic nervous system. Some block activation of all types of $\beta$-adrenergic receptors and others are selective for one of the three known types of beta receptors, designated $\beta 1, \beta 2$ and $\beta 3$ receptors. $\beta 1$-adrenergic receptors are located mainly in the heart and in the kidneys. $\beta 2$-adrenergic receptors are located mainly in the lungs, gastrointestinal tract, liver, uterus, vascular smooth muscle, and skeletal muscle. $\beta 3$-adrenergic receptors are located in fat cells. Activation of the beta receptor in the cardiac myocyte activates a glycoprotein, stimulating adenyl cyclase to convert ATP into CAMP (figure 2).

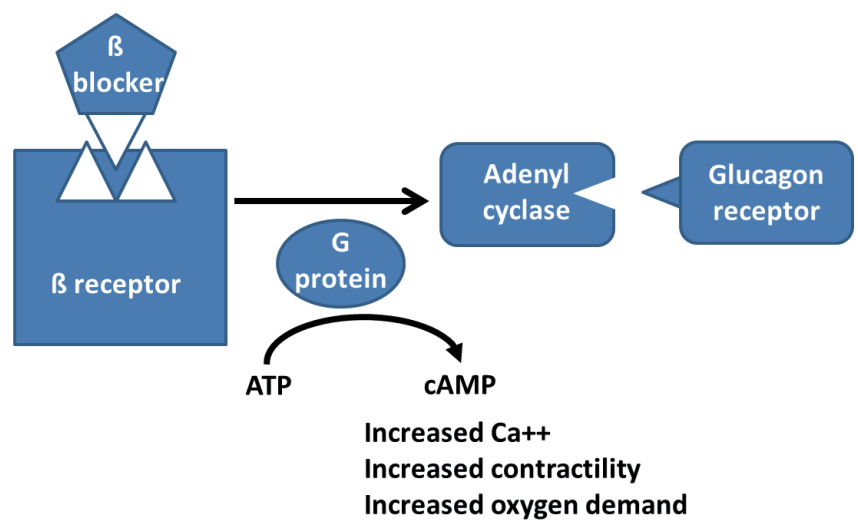

Figure 2 - effects of beta receptor stimulation in a cardiac myocyte.

In 1964, James Black synthesized the first clinically significant beta blockers—propranolol; it revolutionized the medical management of angina pectoris. (11)

For more than a quarter of a century, beta-blockers have been a cornerstone in the treatment of patients with myocardial infarction.

In the clinical guidelines, treatment with beta-blockers for STEMI patients is recommended. (12) The American College of Cardiology Foundation/American Heart Association (ACCF/ AHA) and the European Society Cardiology (ESC) gave a class I recommendation for oral beta-blockers within the first 24 hours in patients with myocardial infarction and a class lla indication for intravenous beta-blockers for patients who are hypertensive or having ongoing ischemia. 
The evidence of mortality reduction with beta-blockers after reperfusion therapy is limited. $(12,13)$ Whether administration before reperfusion improves clinical outcome or reduces myocardial infarct size remains to be elucidated. Some experimental studies suggest that beta-blockers decrease the extent of myocardial necrosis, whereas others have shown no effect. (14-17) In clinical studies in STEMI, the effect of early beta-blockade results mostly from the prereperfusion era, with inconclusive results. (18-21) In the era of thrombolysis, 2 randomized controlled trials testing the effect of beta-blockers in STEMI show no reduction in mortality with beta-blocker treatment. $(22,23)$ In the era of primary percutaneous coronary intervention ( $\mathrm{PCI}), 2$ randomized controlled trials study the effect of early beta-blocker treatment. Hanada et al observed in a small study $(n=96)$ that continuous intravenous landiolol immediately after primary PCI was associated with an improvement of left ventricular (LV) function. (24) The METOCARD-CNIC trial $(n=220)$ shows that intravenous metoprolol administrated before primary $\mathrm{PCI}$ reduces infarct size and preservation of LV function. (25) In METOCARD-CNIC, only patients with an anterior location of STEMI are included, and the trial is neither blinded nor placebo controlled.

\section{OUTLINE OF THIS THESIS.}

The aim of this thesis is to assess the effect of early, prehospital administration before reperfusion of intravenous metoprolol on myocardial infarct size and long term clinical outcome in patients with STEMI eligible for primary PCI on top of standard treatment.

These research questions were assessed by using the data from the prospective double blinded placebo controlled randomized clinical trial of the: Eary $\beta$-blocker Administration before primary $\mathrm{PCI}$ in patients with ST-elevation Myocardial Infarction trial. The Early BAMI trial.

In Chapter 2, an overview of early beta-blocker treatment in STEMI patients in the thrombolytic era is described. Also, the results of a multicenter, nonrandomized, prospective observational cohort study in which STEMI patients were treated with immediate or delayed administration of oral bisoprolol $2.5 \mathrm{mg}$. Chapter 3 describes the rationale and design of the Early-BAMI trial that will investigate the impact of intravenous metoprolol administration before primary PCI for STEMI on myocardial infarct size as measured with MRI at 30 days. In Chapter 4 the association between chronic beta-blocker treatment and haemodynamics at admission in patients with STEMI treated by primary percutaneous coronary intervention is investigated on the risk of cardiogenic shock (CS) and pre-shock. In Chapter $\mathbf{5}$ and $\mathbf{6}$ data are presented of the Early-BAMI trial, investigating the impact of intravenous metoprolol administration before primary PCI for STEMI on myocardial infarct size as measured with 
MRI at 30 days and clinical outcome on short- (30 day) and long-term (one year). In chapter 7 we describe a patient-pooled meta-analysis of randomized clinical trials to evaluating the efficacy and safety of intravenous beta-blockers before primary PCI for STEMI. The objective of this patient-pooled meta-analysis was to evaluate the short-term infarct size and one-year clinical outcomes of intravenous beta-blockers in STEMI patients undergoing primary $\mathrm{PCI}$. 


\section{REFERENCES}

1. Lloyd-Jones D, Adams RJ, Brown TM et al. Executive summary: heart disease and stroke statistics--2010 update: a report from the American Heart Association. Circulation 2010;121:948-54.

2. Widimsky P, Wijns W, Fajadet J et al. Reperfusion therapy for ST elevation acute myocardial infarction in Europe: description of the current situation in 30 countries. Eur Heart J 2010;31:943-57.

3. Libby P. Current concepts of the pathogenesis of the acute coronary syndromes. Circulation 2001;104:365-72.

4. Ross AM, Coyne KS, Moreyra E et al. Extended mortality benefit of early postinfarction reperfusion. GUSTO-I Angiographic Investigators. Global Utilization of Streptokinase and Tissue Plasminogen Activator for Occluded Coronary Arteries Trial. Circulation 1998;97:1549-56.

5. Zijlstra F, de Boer MJ, Hoorntje JC, Reiffers S, Reiber JH, Suryapranata H. A comparison of immediate coronary angioplasty with intravenous streptokinase in acute myocardial infarction. $N$ Engl J Med 1993;328:680-4.

6. Grines $C L$, Browne KF, Marco J et al. A comparison of immediate angioplasty with thrombolytic therapy for acute myocardial infarction. The Primary Angioplasty in Myocardial Infarction Study Group. N Engl J Med 1993;328:673-9.

7. Fokkema ML, James SK, Albertsson P et al. Population trends in percutaneous coronary intervention: 20-year results from the SCAAR (Swedish Coronary Angiography and Angioplasty Registry). J Am Coll Cardiol 2013;61:1222-30.

8. Schaper J, Schaper W. Time course of myocardial necrosis. Cardiovasc Drugs Ther 1988;2:17-25.

9. Antman EM, Hand M, Armstrong PW et al. 2007 Focused Update of the ACCIAHA 2004 Guidelines for the Management of Patients With ST-Elevation Myocardial Infarction: a report of the American College of Cardiology/American Heart Association Task Force on Practice Guidelines: developed in collaboration With the Canadian Cardiovascular Society endorsed by the American Academy of Family Physicians: 2007 Writing Group to Review New Evidence and Update the ACCIAHA 2004 Guidelines for the Management of Patients With ST-Elevation Myocardial Infarction, Writing on Behalf of the 2004 Writing Committee. Circulation 2008;117:296-329.

10. Ibanez B, James S, Agewall S et al. 2017 ESC Guidelines for the management of acute myocardial infarction in patients presenting with ST-segment elevation: The Task Force for the management of acute myocardial infarction in patients presenting with ST-segment elevation of the European Society of Cardiology (ESC). Eur Heart J 2017.

11. Stapleton MP. Sir James Black and propranolol. The role of the basic sciences in the history of cardiovascular pharmacology. Tex Heart Inst J 1997;24:336-42.

12. Van de Werf F, Bax J, Betriu A et al. Management of acute myocardial infarction in patients presenting with persistent ST-segment elevation: the Task Force on the Management of STSegment Elevation Acute Myocardial Infarction of the European Society of Cardiology. Eur Heart J 2008;29:2909-45.

13. Dargie HJ. Effect of carvedilol on outcome after myocardial infarction in patients with leftventricular dysfunction: the CAPRICORN randomised trial. Lancet 2001;357:1385-90.

14. Hammerman H, Kloner RA, Briggs LL, Braunwald E. Enhancement of salvage of reperfused myocardium by early beta-adrenergic blockade (timolol). J Am Coll Cardiol 1984;3:1438-43.

15. Rasmussen $M M$, Reimer $K A$, Kloner RA, Jennings $R B$. Infarct size reduction by propranolol before and after coronary ligation in dogs. Circulation 1977;56:794-8.

16. Kern KB, Hilwig RW, Warner A, Basnight M, Ewy GA. Failure of intravenous metoprolol to limit acute myocardial infarct size in a nonreperfused porcine model. Am Heart J 1995;129:650-5. 
17. Lange R, Nieminen MS, Kloner RA. Failure of pindolol and metoprolol to reduce the size of non-reperfused infarcts in dogs using area at risk techniques. Cardiovasc Res 1984;18:37-43.

18. Reduction of infarct size by the early use of intravenous timolol in acute myocardial infarction. International Collaborative Study Group. Am J Cardiol 1984;54:14E-15E.

19. Peter $T$, Heng MK, Singh BN et al. Failure of high doses of propranolol to reduce experimental myocardial ischemic damage. Circulation 1978;57:534-40.

20. Rude RE, Buja LM, Willerson JT. Propranolol in acute myocardial infarction: the MILIS experience. Am J Cardiol 1986;57:38F-42F.

21. Yusuf $S$, Sleight $P$, Rossi $P$ et al. Reduction in infarct size, arrhythmias and chest pain by early intravenous beta blockade in suspected acute myocardial infarction. Circulation 1983;67:132-41.

22. Chen ZM, Pan HC, Chen YP et al. Early intravenous then oral metoprolol in 45,852 patients with acute myocardial infarction: randomised placebo-controlled trial. Lancet 2005;366:1622-32.

23. Metoprolol in acute myocardial infarction (MIAMI). A randomised placebo-controlled international trial. The MIAMI Trial Research Group. Eur Heart J 1985;6:199-226.

24. Hanada K, Higuma T, Nishizaki F et al. Randomized study on the efficacy and safety of landiolol, an ultra-short-acting beta1-adrenergic blocker, in patients with acute myocardial infarction undergoing primary percutaneous coronary intervention. Circ J 2012;76:439-45.

25. Ibanez B, Macaya C, Sanchez-Brunete $V$ et al. Effect of early metoprolol on infarct size in STsegment-elevation myocardial infarction patients undergoing primary percutaneous coronary intervention: the Effect of Metoprolol in Cardioprotection During an Acute Myocardial Infarction (METOCARD-CNIC) trial. Circulation 2013;128:1495-503. 



\section{The Sooner, the Better: Early Beta- Blocker Administration in Patients With ST-Elevation Myocardial Infarction}

Crit Care Med. 2013 Jun;41(6):1566-8

Vincent Roolvink, Arnoud W. J. van 't Hof, Iwan C. C. van der Horst 

Beta-blockers are first-line treatment of patients with an acute coronary syndrome. They have demonstrated to reduce mortality when administered after an acute myocardial infarction (MI) $(1,2)$. They also decrease the prevalence of recurrent $\mathrm{MI}$, recurrent ischemia, or life-threatening arrhythmias and prevent left ventricular remodeling $(3,4)$. Therefore, the use of oral beta-blockade constitutes a class I indication in clinical guidelines (5). Whether early administration of beta-blockers is effective during the acute phase of $\mathrm{Ml}$ and before reperfusion is not yet clear. Some preclinical studies suggest that beta-blockers decrease the extent of myocardial necrosis $(6,7)$, although others have shown no effect $(8,9)$. The results of human clinical studies mostly performed in or before the thrombolytic era also are controversial $(1,10)$. In the large ClOpidogrel and Metoprolol in Myocardial Infarction Trial (COMMIT) trial (11), three boluses of intravenous metoprolol $5 \mathrm{mg}$ administered at least 2 minutes apart, followed by oral administration thereafter, had no effect on survival compared with those who received placebo. The prevalence of recurrent MI or ventricular fibrillation was significantly lower in patients who were treated with early beta-blocker (absolute reduction $0.5 \%$ for both). This was counterbalanced by a $1.1 \%$ higher prevalence cardiogenic shock. In the COMMIT trial, patients scheduled for reperfusion by primary percutaneous coronary intervention ( $\mathrm{PCl}$ ) were excluded from the trial. Based on this trial, it was suggested that it may generally be more prudent to start beta-blocker therapy only after a patient's hemodynamic condition has stabilized after MI.

In the era of primary $\mathrm{PCl}$, the effect of early administration of beta-blockers has been analyzed in a limited number of small nonrandomized trials (12). In a swine model Ml study, a single dose of metoprolol during ongoing $\mathrm{Ml}$ and before reperfusion resulted in a significant greater salvaged myocardium (13). Currently, two randomized trials are investigating the administration of beta blockers before primary $\mathrm{PCI}$ in ST-elevation myocardial infarction (STEMI) patients. The METOprolol in CARDioproteCtioN during an acute myocardial InfarCtion (METOCARD-CNIC) is conducted in Madrid, Spain. It uses the same beta-blocker scheme as in the COMMIT in anterior STEMI patients during ambulance transportation to the center with PCI facilities. Results from this trial are expected in 2013 (14). The second trial is running in Zwolle and Groningen, The Netherlands, Early Beta-blocker Administration before reperfusion in patients with ST-elevation Myocardial Infarction, who are planned to undergo primary PCI (EARLY-BAMI), which is a double-blinded, placebo-controlled randomized trial, administrating intravenous metoprolol $5 \mathrm{mg}$ or placebo in the ambulance in STEMI patients, and a second $5 \mathrm{mg}$ bolus upon arrival in the catheterization laboratory before primary $\mathrm{PCl}$. Results from this trial are expected at the end of 2014 (15). In this issue of Critical Care Medicine, Hirschl et al (16) report results of a multicenter, nonrandomized, prospective observational cohort study in five primary care hospitals and one $\mathrm{PCl}$-capable hospital in the western part of lower Austria. STEMI patients were treated according to the decision of the physician with immediate (within 30 min after first ECG) or delayed (24 hr after first ECG) administration 
of oral bisoprolol $2.5 \mathrm{mg}$. Exclusion criteria were systolic blood pressure less than $100 \mathrm{~mm}$ $\mathrm{Hg}$, bradycardia (heart rate $<60 / \mathrm{min}$ ), higher degree atrioventricular-block, and clinical signs of heart failure. The primary endpoint was all-cause mortality. From June 2006 to December 2010, they included 664 STEMI patients, 343 (52\%) received immediate and 321 (48\%) delayed beta-blockade. Reperfusion strategy depended on the time interval between symptom onset and first medical contact. If the time interval was below 120 minutes, a thrombolytic treatment was given, followed by transfer to the $\mathrm{PCI}$ center. All other patients were directly transferred to the $\mathrm{PCl}$ center for primary $\mathrm{PCI}$ less than 120 minutes from first medical contact. In the survival analysis, they excluded patients who died within the first 48 hours, that is, 5 patients in the immediate compared with 19 patients in the delayed group (1.5\% vs. 5.9\%). This was done to reduce potential bias, assuming that patients dying within the first 48 hours have died independently of immediate or delayed beta-blocker treatment. At baseline, patients in the immediate group were younger and had higher blood pressures and heart rate. The average time interval between first ECG and immediate beta-blocker administration was only 12 minutes. Despite the exclusion of patients who died within 48 hours, Hirschl et al found a significant reduction in all-cause mortality of immediate compared with delayed beta-blocker treatment (10.7\% vs. $19.2 \%$ ). Multivariable regression analysis identified immediate beta-blocker therapy as in-depended protective treatment for all-cause mortality. The importance of this study lies primarily in the comparison of immediate ( $<30 \mathrm{~min}$ ) with a delayed administration beta-blocker administration and not placebo. Furthermore, most patients (59\%) in this study were treated by primary $\mathrm{PCI}$. Furthermore, they investigated the effect on all-cause mortality, whereas most other studies focused on infarct size. In contrast to some previous studies, the rate of cardiogenic shock was overall very low $(0.4 \%)$ and did not increase in patients with immediate beta-blocker therapy. This may be explained by the timing of the beta-blocker administration or by the exclusion of patients with signs of heart failure. Some limitations could be mentioned. First, the observational design introduces the risk of selection bias, especially since immediate or delayed treatment was chosen by individual physicians. The higher blood pressure and heart rate in the early group underline the potential bias. Second, the observations only account patients without heart failure, a group of higher risk, and potential greater benefit. Finally, the percentage of primary $\mathrm{PCI}$ (59\%) compared with other western-European countries is low. According to the current guidelines, primary $\mathrm{PCl}$ is the preferred strategy if a $\mathrm{PCl}$ center is located within 90 minutes (5). In this study, the PCl center was located at an average distance of $82 \mathrm{~km}$. Nevertheless, this well-performed observational cohort study clearly demonstrates that in STEMI patients, tolerating early beta-blocker treatment have a favorable survival and importantly did not increase the rate of cardiogenic shock in patients without signs of heart failure at treatment initiation. If upcoming trials (METOCARD-CNIC trial and EARLY-BAMI trial) confirm that early beta-blocker administration in the prehospital setting before reperfusion is favorable, it should become standard treatment. 


\section{REFERENCES}

1. Metoprolol in Acute Myocardial Infarction (MIAMI). A randomized placebo- controlled international trial: the MIAMI Trial Research Group. Eur Heart J 1985; 6:199-226

2. Randomized trial of intravenous atenolol among 16027 cases of suspected acute myocardial infarction: ISIS-1: First International Study of Infarct Survival Collaborative Group. Lancet 1986; 2:57- 66

3. Domanski MJ, Zipes DP, Schron E: Treatment of sudden cardiac death. Current understandings from randomized trials and future research directions. Circulation 1997; 95:2694-2699

4. López-Sendón J, Swedberg K, McMurray J, et al; Task Force on Beta- Blockers of the European Society of Cardiology: Expert consensus document on beta-adrenergic receptor blockers. Eur Heart J 2004;25:1341-1362

5. Steg PG, James SK, Atar D, et al. ESC Guidelines for the management of acute myocardial infarction in patients presenting with ST-segment elevation: The Task Force on the management of ST-segment elevation acute myocardial infarction of the European Society of Cardiology (ESC). Eur Heart J 2012;33:2569-2619

6. Hammerman $H$, Kloner RA, Briggs $L L$, et al: Enhancement of salvage of reperfused myocardium by early beta-adrenergic blockade (timolol). J Am Coll Cardiol 1984; 3:1438-1443

7. Rasmussen MM, Reimer KA, Kloner RA, et al: Infarct size reduction by propranolol before and after coronary ligation in dogs. Circulation 1977;56:794-798

8. Van de Werf F, Vanhaecke J, Jang IK, Flameng W, Collen D, De Geest H: Reduction in infarct size and enhanced recovery of systolic function after coronary thrombolysis with tissue-type plasminogen activator combined with beta-adrenergic blockade with metoprolol. Circulation 1987; 75:830-836

9. Kern KB, Hilwig RW, Warner A, et al: Failure of intravenous metoprolol to limit acute myocardial infarct size in a nonreperfused porcine model. Am Heart J 1995; 129:650-655

10. Peter $T$, Heng MK, Singh BN, et al: Failure of high doses of propranolol to reduce experimental myocardial ischemic damage. Circulation 1978; 57:534 540

11. COMMIT (ClOpidogrel and Metoprolol in Myocardial Infarction Trial) Collaborative Group: Early intravenous then oral metoprolol in 45852 patients with acute myocardial infarction: randomized placebo-controlled trial. Lancet 1995; 366:1622-1632

12. Brandler E, Paladino L, Sinert R: Does the early administration of beta blockers improve the in-hospital mortality rate of patients admitted with acute coronary syndrome? Acad Emerg Med 2010;17:1-10

13. Ibanez B, Prat-González S, Speidl WS, et al: Early metoprolol administration before coronary reperfusion results in increased myocardial salvage: analysis of ischemic myocardium at risk using cardiac magnetic resonance. Circulation 2007; 115:2909-2916

14. Ibanez B, Fuster V, Macaya C, et al: Study design for the "effect of METOprolol in CARDioproteCtion during an acute myocardial InfarCtion" (METOCARD-CNIC): A randomized, controlled parallelgroup, observer-blinded clinical trial of early pre-reperfusion metoprolol administration in ST-segment elevation myocardial infarction. Am Heart J 2012; 164:473-480.e5

15. Roolvink V, Rasoul S, Ottervanger JP, et al: Study design for Early Beta blocker Administration before reperfusion in patients with ST-elevation Myocardial Infarction who are planned to undergo primary PCI. (EARLY-BAMI): A randomized, placebo controlled, double-blinded clinical trial of early administration of intravenous betablockers in patients with ST-elevation myocardial 
infarction before planned primary PCl. Available at: http://www.clinicaltrialsregister.eu. Accessed November 13, 2012

16. Hirschl MM, Wollmann CG, Erhart F, et al: Benefit of Immediate Beta- Blocker Therapy on Mortality in Patients With ST-Segment Elevation Myocardial Infarction. Crit Care Med 2012; 41:1396-1404 


Rationale and Design of a Doubleblind, Multicenter, Randomized, Placebo controlled Clinical trial of Early Administration of Intravenous Beta-blockers in Patients with STelevation Myocardial Infarction before Primary PCl.: EARLY Beta-blocker Administration before primary $\mathrm{PCl}$ in patients with ST-elevation Myocardial Infarction (EARLY-BAMI) trial.

Am Heart J. 2014;168(5):661-6.

Vincent Roolvink, Saman Rasoul, Jan Paul Ottervanger, Jan-Henk

E. Dambrink, Erik Lipsic, Iwan C. C. van der Horst, Bart de Smet, Elvin Kedhi, Marcel Gosselink, Jan J. Piek, Vicente Sanchez-Brunete, Borja Ibanez, Valentin Fuster, ArnoudW. J. van't Hof, on behalf of the EARLY-BAMI investigators 


\section{ABSTRACT}

\section{Background}

$\beta$-Blockers have a class 1a recommendation in the treatment of patients with ST-elevation myocardial infarctions (STEMIs), as they are associated with a reduced mortality, recurrent myocardial infarction, life-threatening arrhythmias, and with prevention of unfavorable left ventricular remodeling. Whether early administration before primary percutaneous coronary intervention $(\mathrm{PCl})$ of intravenous $\beta$-blockers reduces the infarct size in the current era is unknown.

\section{Hypothesis}

We postulate that the early administration of $\beta$-blockers will reduce the myocardial infarcted area as assessed by magnetic resonance imaging (MRI) at 30 days. Designed in a multinational, multicenter, double-blind, placebo-controlled, randomized trial, patients with symptoms and signs of STEMI and transferred to a hospital for primary $\mathrm{PCI}$ will be randomized in a 1:1 fashion to intravenous metoprolol ( $5 \mathrm{mg}$ twice daily) administration or placebo. Before admission, study treatment will be started as soon as possible after the diagnosis of STEMI. After admission, primary PCI will be performed as per standard of care. After primary PCI, medical treatment will occur as per current guidelines in all patients, including the use of oral $\beta$-blockers. The primary end point is the myocardial infarct size as assessed by MRI at 30 days. Based on a superiority design and assuming an 18\% relative infarct size reduction (from $28 \%$ to $23.5 \%$ ), 408 patients are required to be enrolled, accounting for $20 \%$ drop-out ( $a=.05$ and power $=80 \%$ ).

\section{Summary}

The EARLY-BAMI trial is a multinational, multicenter, double-blind, placebo-controlled, randomized clinical trial that will investigate the impact of intravenous metoprolol administration before primary PCI for STEMI on myocardial infarct size as measured with MRI at 30 days. (Am Heart J 2014;168:661-6.) 


\section{BACKGROUND}

Despite advances in the care for patients with ST elevation myocardial infarction (STEMI), mortality in these patients remains relative high, especially in an allcomer situation.1 Although early diagnosis and treatment have improved outcome of these patients, additional interventions early after onset of ischemia might further improve outcome. In the clinical guidelines, treatment with $\beta$-blockers for STEMI patients is recommended. 2 The evidence of mortality reduction with $\beta$-blockers after reperfusion therapy is limited.2-4 Whether administration before reperfusion improves clinical outcome or reduces myocardial infarct size remains to be elucidated. Some experimental studies suggest that $\beta$-blockers decrease the extent of myocardial necrosis,4-6 whereas others have shown no effect.7-9 In clinical studies in STEMI, the effect of early $\beta$-blockade results mostly from the prereperfusion era, with inconclusive results (Table 1).15-18 In the era of thrombolysis, 2 randomized controlled trials testing the effect of $\beta$-blockers in STEMI show no reduction in mortality with $\beta$-blocker treatment.10,11 In the era of primary percutaneous coronary intervention ( $\mathrm{PCI}), 2$ randomized controlled trials study the effect of early $\beta$-blocker treatment. Hanada et al14 observed in a small study $(n=$ 96) that continuous intravenous landiolol immediately after primary $\mathrm{PCI}$ was associated with an improvement of left ventricular (LV) function. The METOCARD-CNIC trial $(n=220)$ shows that intravenous metoprolol administrated before primary $\mathrm{PCl}$ reduces infarct size and preservation of LV function.12,19 In METOCARD-CNIC, only patients with an anterior location of STEMI are included, and the trial is neither blinded nor placebo controlled. 19 We describe the design of the EARLY-BAMI trial, in which $\beta$-blocker administration before primary PCI will be studied in patients with STEMI, with a double-blinded, placebo-controlled design.

\section{METHODS}

\section{Objectives}

The primary objective of the EARLY-BAMI trial (medical ethical committee (Zwolle, Netherlands) no.: 10.10111, www. clinicaltrialsregister.eu with EudraCT no.: 2010-023394-19.) is to assess the effect of early, prehospital administration before reperfusion of intravenous metoprolol on myocardial infarct size in patients with STEMI eligible for primary $\mathrm{PCI}$ on top of standard $\beta$-blocker treatment less than 24 hours post-PCI.

\section{Study design}

The EARLY-BAMI is a multicenter, multinational, double-blind, placebo-controlled randomized trial. A total of 8 centers in The Netherlands and Spain will enroll patients. These centers have a long-standing experience in treating STEMI patients and all work within an STEMI network. The trial is conducted with a research grant of de Dutch Heart Foundation (Utrecht, 


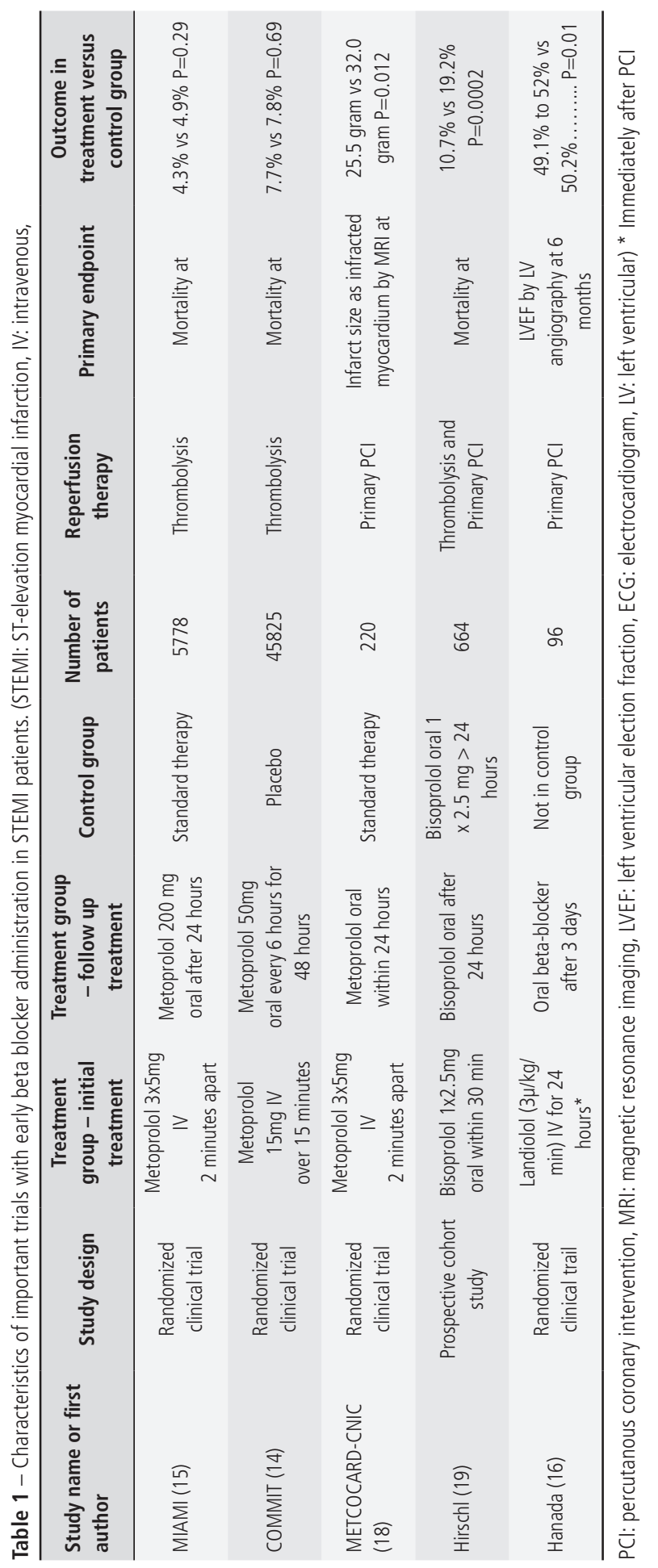


Netherlands) (no. 2010B125) and an unrestricted grant of Medtronic (Heerlen, The Netherlands) for additional analyses. The authors are solely responsible for the design and conduct of the study; all study analyses, the drafting and editing of the paper, and its final contents.

\section{STUDY PROTOCOL}

The study protocol flowchart is depicted in the Figure. The diagnosis of STEMI will be made by the ambulance medical personnel. Electrocardiogram transmission to a physician at the $\mathrm{PCl}$ center can be performed to allow confirmation of the diagnosis. After the diagnosis of STEMI in the ambulance, medical treatment in all patients will occur as per current guidelines with the administration of $500 \mathrm{mg}$ of aspirin intravenous, $180 \mathrm{mg}$ of Ticagrelor oral, and 5,000 International Units of unfractionated heparin intravenous. Patients will be randomized in a 1:1 fashion to pretreatment with $5 \mathrm{mg}$ intravenous metoprolol or matching placebo followed by a second bolus of study drug in the catheterization laboratory. The ambulance personnel and/or the investigator will complete the administration/enrolment procedure: after measurement of blood pressure (millimeters of mercury), heart rate (beats per minute), and oxygen saturation (with pulse oximetry), inclusion and exclusion criteria will be checked (Table 2). If patients fulfill with the inclusion/exclusion criteria, verbal informed consent will be obtained. The verbal consent in the ambulance will be obtained by a paramedical ambulance nurse in The Netherlands and by a physician in Spain. If this is obtained a blinded study, medication box is opened. This box contains 2 vials with metoprolol 5 mg or matched placebo and will be labeled with a number that corresponds with the randomization list. Randomization takes place without stratification and in blocks of 4 . The first bolus medication will be given in the ambulance, the second bolus will be given in the PCI hospital at the catheterization laboratory before the $\mathrm{PCI}$ procedure (if systolic blood pressure is $100 \mathrm{mmHg}$ and heart rate 60 beat/min). One kit for ambulance as well as hospital use will be stored per ambulance. Study drug stock for resupply to the ambulance will be at the $\mathrm{PCI}$ center. For resupply of the ambulance, the consecutive study drug kits will be taken. Resupply of study drug kits at the $\mathrm{PCl}$ hospital takes place on regular basis. Patients participating in the trial will be treated during hospital admission and thereafter according current guidelines. 2 During $\mathrm{PCl}$, the use of thrombus aspiration and the use of glycoprotein IIb-Illa inhibitors will be encouraged. In addition, patients with a stent indication will be treated with a secondgeneration drug-eluting stent. All patients receive oral metoprolol within 12 hours after $\mathrm{PCl}$, according current guidelines during hospitalization. At discharge, all patients will receive oral metoprolol at a dose recommended by their treating physician. Follow-up will include visits at the outpatient clinic at each center and will allow us to obtain data for follow-up at 30 days and 12 months after admission. 


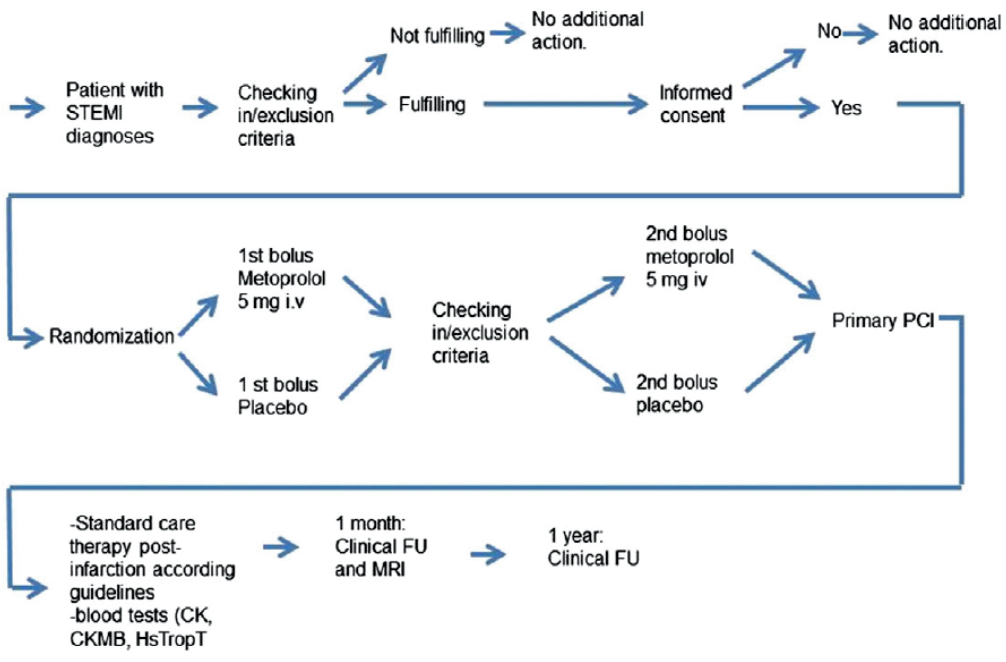

Flowchart of EARLY-BAMI trial, treatment, and randomization procedure.

\section{Figure.}

Table 2 - In- and exclusion criteria of the Early-BAMI trial

\begin{tabular}{|c|c|}
\hline Inclusion criteria & Exclusion criteria \\
\hline $\begin{array}{l}\text { Patients } \geq 18 \text { years of age with symptoms of acute ST-elevation } \\
\text { myocardial infarction of more than } 30 \text { min but less than } 12 \text { hours. }\end{array}$ & Severe hypotension (systolic blood pressure $\leq 100 \mathrm{mmHg}$ ) \\
\hline $\begin{array}{l}\text { ST-segment elevation of more than } 1 \mathrm{mV} \text { in two adjacent } \\
\text { electrocardiograph (ECG) leads or new LBBB. }\end{array}$ & $\begin{array}{l}\text { Cardiogenic shock or signs of heart failure, Killip III (defined } \\
\text { as severe dyspnea, oxygen saturation }<92 \% \text {, systolic blood } \\
\text { pressure }<100 \mathrm{mmHg} \text {, heart rate }>110 / \mathrm{min} \text { ) }\end{array}$ \\
\hline Verbal followed by written informed consent. & Known with asthma bronchiale \\
\hline \multirow[t]{5}{*}{ PCI-center located within 90 minutes of transportation. } & Severe sinusbradycardia (<60 bpm) \\
\hline & History of previous myocardial infarction \\
\hline & Unable to provide informed consent \\
\hline & Pacemaker or ICD implantation. (no MRI possible) \\
\hline & Patient is (suspected to be) pregnant or breastfeeding \\
\hline
\end{tabular}

Abbreviations: ECG, Electrocardiogram; LBBB, left bundle branch block; ICD, implanted cardioverter / defibrillators.

\section{End points}

The primary end point is myocardial infarct size as measured by cardiac magnetic resonance imaging (MRI) at 30 days. The secondary efficacy end points are peak creatine kinase (CK), peak CK-MB, troponin at 24 hours, and area under the CK and CK-MB curve during first 24 hours, residual ST deviation 1 hour after PCl/coronary angiogram, ventricular arrhythmias requiring defibrillation during transportation and hospitalization and major adverse cardiac events (MACE), defined as cardiac death, nonfatal reinfarction, or target vessel revasculariza- 
tion at 30 days and 1-year follow-up. The secondary safety end points include symptomatic bradycardia, symptomatic hypotension, and cardiogenic shock.

\section{STATISTICAL CONSIDERATIONS}

\section{Sample size}

The sample size is determined for the primary end point of the trial by a power analysis with reasonable clinical and statistical assumptions. With an expected infarct size of $28 \% 20$ in a population under standard treatment (no $\beta$-blockers pre-PCI), we considered a reduction in infarct size from $28 \%$ to $23.5 \%$ clinical relevant. Assuming an SD of the myocardial infarction (MI) size measured by MRI equal to $10 \%, 21$ the power analysis indicated a total sample size of 326 patients (163 subjects in each group) is needed to achieve $80 \%$ power with significance level of 0.05 to detect a difference in infarct size. We anticipate up to $10 \%$ of wrong recruitments/no evidence of infarction as determined by cardiac biomarkers/consent withdrawals and up to an additional $10 \%$ of the randomized population with claustrophobia or any other condition precluding the MRI performance. Taking into consideration these potential losses, we foresee that we have to recruit 408 subjects (204 subjects in each treatment group) to compensate for subject attrition related to the lack of information for the primary end point. If needed, the data and safety monitoring board can advise to increase the sample size to maintain statistical power to detect a significant difference. The sample size calculation is based on a Student $t$ test for independent groups. Patients who die after MRI will be included in the primary outcome analysis. Patients who die before performance of the magnetic resonance image will not be included in the primary outcome analysis; however, they will be included in the secondary outcome analysis because death within 1 year is a secondary end point.

\section{Statistical analysis}

Statistical analysis will be performed with the Statistical Package for the Social Sciences (SPSS Inc, Chicago, IL) version 16.0.1. Continuous data will be expressed as mean \pm SD of mean and categorical data as percentage, unless otherwise denoted. The analysis of variance and the $x 2$ test will be appropriately used for continuous and categorical variables, respectively. The incidence of MACE within 1 year will be calculated by the Kaplan-Meier product-limit method. The Log-rank test will be used to evaluate differences in MACE between the 2 treatment groups. For all analyses, statistical significance will be assumed when the 2-tailed $P<0.05$. 


\section{Cardiac MRI analysis}

All patients included in the study and meeting the inclusion/ exclusion criteria will undergo an MRI approximately 1-month post-MI ( \pm 10 days). Patients recruited in The Netherlands will undergo an MRI study in the Isala Hospital. Patients recruited in Spain, Madrid, will undergo an MRI in the "human cardiovascular imaging research laboratory" in CNIC. All MRI studies will be performed blinded to treatment allocation and according to a centralized protocol. Dedicated sequences evaluating cardiac function, myocardial perfusion, and myocardial necrosis/fibrosis will be performed. All MRI studies are stored and further analyzed in a central core laboratory in CNIC in Madrid, Spain. Analysis of MRI studies will be performed in a random manner by expert observers blinded to treatment allocation. Quantification will be performed on a separate workstation using a dedicated software package (QMass MR 7.4; Medis, Leiden, the Netherlands). In all MRI studies, the following information will be determined: LV volumes, LV function, and myocardial delayed enhancement. Myocardial necrosis will be defined by the extent of abnormal delayed enhancement. All measurements will be expressed as percentage of the total LV myocardial volume; the absolute MI size will be also quantified in grams. All results will be given in absolute numbers and indexed by patients' body surface. The null hypothesis to be tested is that there is no difference between the 2 treatment groups in infarct size measured by MRI at 1-month postinfarction. Estimates of the difference between the 2 groups will be estimated by multivariable linear regression adjusted for the participating hospital center and the stratification variables. We will also adjust for baseline variables as potential confounders. Stop of study drug and study drug unblinding. If at any time during the study, the investigator responsible for the clinical care of the patient decides that the study drug is contraindicated, administration of the study drug can be stopped. Unblinding of study drug treatment will occur only when critical to ensuring the health, welfare, or safety of the patient. A randomization technician will provide access to the actual treatment assignment. The patient will continue to be followed up for the duration of the study. The reason for unblinding must be documented in the patient's chart as well as on the case report form.

\section{Data collection and follow-up}

The following variables from the patient files will be collected by an independent Contract Research Organization organization (DIAGRAM, Zwolle, The Netherlands): age, gender, history of hypertension, diabetes, hyperlipidemia, smoking, medication, previous MI, angiographic data, laboratory results, and discharge medication. Follow-up information will be obtained from clinical records, from information gathered of the patient's general physician or by direct telephone interview with the patient, by independent research nurses from the Contract Research Organization. 


\section{Ethics}

The investigation conforms with the principles outlined in the Declaration of Helsinki $\mathrm{Br}$ Med J 1964, ii: 177). The study was approved by the committee on research ethics of the hospitals.

\section{Prespecified subgroups for analysis}

The following subgroups are prespecified for analysis: anterior versus nonanterior infarctions, patients presenting b6 hours after symptom onset versus patients presenting $<6$ hours and occluded (Thrombolysis In Myocardial Infarction 0 and 1 flow) infarct-related vessel at time of coronary angiogram versus open (Thrombolysis In Myocardial Infarction 2 and 3 flow) infarct-related vessel.

\section{Duration of the study}

The EARLY-BAMI trial started including patients in April 2012. It is expected that recruitment will be completed within 24 to 36 months. Therefore, it is expected that the patient inclusion will be finished in December 2014. Magnetic resonance imaging data (primary end point will be completed in April 2015) and 1-year follow-up data will be completed in December 2015.

\section{SUMMARY AND EXPECTED RESULTS}

The EARLY-BAMI study is being conducted to determine whether prehospital administration of metoprolol will result in improvement in residual myocardial infarct size as measured by MRI approximately 1 month after primary $\mathrm{PCI}$. The results of this study may have a direct impact on the future prehospital treatment for patients with STEMI and on future treatment recommendations.

\section{DISCUSSION}

$\beta$-Blockers are drugs with multiple actions on the heart. Blockade of $\beta 1$ receptors results in slowing of heart rate, reduction in myocardial contractility, and lowering of systemic blood pressure. In the context of acute myocardial infarction, which represents a state of reduced oxygen supply to the affected portion of the heart, these effects may be beneficial, as they result in reduced myocardial workload and oxygen demand. Furthermore, $\beta$-blockers decrease the incidence of life-threatening arrhythmias, reinfarction, and recurrent ischemia, preventing LV remodeling.10,12-14,19-22 They have demonstrated to be beneficial, resulting in a mortality reduction in heart failure and when administered after MI. But there is debate whether prereperfusion administration of intravenous $\beta$-blockers may reduce reperfusion injury as 
compared with postreperfusion administration. Two animal studies suggested decreased infarct size after early $\beta$-blocker administration.23,24 In the thrombolytic era, 2 clinical trials on beneficial effects of $\beta$-blockers before thrombolysis did not show clear results. The MIAMI trial tested the effect of prereperfusion metoprolol ( $3 \times 5 \mathrm{mg}$ intravenous) versus placebo in STEMI ( $n=5778$ ) treated by thrombolysis and could not demonstrate any beneficial effect of metoprolol.10 In the COMMIT CC2 trial $(n=45,825), 11$ intravenous metoprolol $3 \times 5 \mathrm{mg}$ intravenous followed by oral administration up to 4 weeks did not improve survival in STEMI patients. However, this was mainly caused by a higher incidence of cardiogenic shock in patients treated by early $\beta$-blocker, possibly due to inclusion of patients with heart failure. In the current era of primary $\mathrm{PCl}$, the METOCARD-CNIC trial showed reduced infarct size and increased LV ejection fraction in STEMI patients without signs of heart failure treated with early intravenous metoprolol.12,25 However, this single study had a limited sample size, was not blinded, not placebo controlled, and included a selected patient group. Our study will be the first study with a large sample size in which $\beta$-blocker administration before primary PCI will be studied in all patients with STEMI, with a double-blinded, placebo-controlled design.

The administration of 2 bolus of $5 \mathrm{mg}$ metoprolol in our study seems aggressive especially in older patients and in patients with multivessel coronary artery disease because $\beta$-blockers may have adverse effects, especially in those with signs of heart failure. However, in the METOCARDCNIC trial, the $\beta$-blocker administrations were even more aggressive, and no excess on side effects were observed.12

\section{LIMITATIONS}

Our trial is powered to demonstrate a potential beneficial effect of $\beta$-blocker in the total population. Although we define several subanalyses, these analyses should be interpreted with caution. It is not possible to blind physicians and nurses for heart rate and blood pressure. However, analyses of MRI (primary end point) are blinded for both heart rate and study medication. The trial investigates only the potential effects of early, prereperfusion $\beta$-blocker administration and not efficacy of $\beta$-blockers later. Although the benefits of $\beta$-blocker use in some subgroups after $\mathrm{Ml}$ can be questioned (as in patients with preserved LV function), our trial was not designed to test these effects. We did not include right ventricular dysfunction as a prespecified subgroup or end point. However, right ventricular function will be determent by MRI, and results may be hypothesis generating. 


\section{REFERENCES}

1. Fokkema ML, James SK, Albertsson P, et al. Population trends in percutaneous coronary intervention: 20-year results from the SCAAR (Swedish Coronary Angiography and Angioplasty Registry). J Am Coll Cardiol 2013;61(12):1222-30.

2. Management of acute myocardial infarction in patients presenting with persistent ST-segment elevation: the Task Force on the Management of ST Segment Elevation Acute Myocardia Infarction of the European Society of Cardiology. Eur Heart J 2008;29:2909-45.

3. The CAPRICORN Investigators. Effect of carvedilol on outcome after myocardial infarction in patients with left-ventricular dysfunction: the CAPRICORN randomised trial. Lancet 2001;357:138590.

4. Feuerstein GZ, Yue $T L$, Cheng $H Y$, et al. Myocardial protection by the novel vasodilating betablocker, carvedilol: potential relevance of anti-oxidant activity. J Hypertens Suppl 1993;11:S41-8.

5. Hammerman $H$, Kloner RA, Briggs $L L$, et al. Enhancement of salvage of reperfused myocardium by early beta-adrenergic blockade (timolol). J Am Coll Cardiol 1984;3:1438-43.

6. Rasmussen MM, Reimer KA, Kloner RA, et al. Infarct size reduction by propranolol before and after coronary ligation in dogs. Circulation 1977;56:794-8.

7. Kern KB, Hilwig RW, Warner A, et al. Failure of intravenous metoprolol to limit acute myocardial infarct size in a nonreperfused porcine model. Am Heart J 1995;129:650-5.

8. Lange $R$, Nieminen MS, Kloner RA. Failure of pindolol and metoprolol to reduce the size of nonreperfused infarcts in dogs using area at risk techniques. Cardiovasc Res 1984;18:37-43.

9. Van de Werf F, Vanhaecke J, Jang IK, et al. Reduction in infarct size and enhanced recovery of systolic function after coronary thrombolysis with tissue type plasminogen activator combined with beta-adrenergic blockade with metoprolol. Circulation 1987;75:830-6.

10. Metoprolol in Acute Myocardial Infarction (MIAMI). A randomized placebo-controlled international trial: the MIAMI Trial Research Group. Eur Heart J 1985;6:199-226.

11. Herlitz J, Waagstein F, Lindqvist J, et al. COMMIT (ClOpidogrel and Metoprolol in Myocardial Infarction Trial) collaborative group. Addition of clopidogrel to aspirin in 45852 patients with acute myocardial infarction: randomized placebo-controlled trial. Effect of metoprolol on the prognosis for patients with suspected acute myocardial infarction and indirect signs of congestive heart failure. Am J Cardiol 1997;80:40J-4J.

12. Ibanez B, Macaya C, Sanchez-Brunete $V$, et al. Effect of early metoprolol on infarct size in STsegment elevation myocardial infarction patients undergoing primary PCl: the METOCARD-CNIC Trial. Circulation 2013;128:1495-503.

13. Hirschl M, Wollmann C, Erhart $F$, et al. Benefit of immediate betablocker therapy on mortality in patients with ST-segment elevation myocardial infarction. Crit Care Med 2013;41:1396-404.

14. Hanada K, Higuma T, Nishizaki F, et al. Randomized study on the efficacy and safety of landiolol, an ultra-short-scting $\beta 1$-adrenergic blocker, in patients with acute myocardial infarction undergoing primary percutaneous coronary intervention. Circ J 2012;76:439-45.

15. The International Collaborative Study Group. Reduction of infarct size with the early use of timolol in acute myocardial infarction. N Engl J Med 1984;310:9-15.

16. Peter $T$, Heng $M K$, Singh $B N$, et al. Failure of high doses of propranolol to reduce experimental myocardial ischemic damage. Circulation 1978;57:534-40.

17. Rude RE, Buja LM, Willerson JT. Propranolol in acute myocardial infarction: the MILIS experience. Am J Cardiol 1986;57:38F-42F. 
18. Yusuf S, Sleight $P$, Rossi $P$, et al. Reduction in infarct size, arrhythmias and chest pain by early intravenous beta blockade in suspected acute myocardial infarction. Circulation 1983;67:I-3241. [Suppl].

19. Ibanez B, Fuster V, Macaya C, et al. Study design for the effect of METOprolol in CARDioproteCtioN during an acute myocardial InfarCtion" (METOCARD-CNIC): a randomized, controlled parallelgroup, observer-blinded clinical trial of early pre-reperfusion metoprolol administration in ST-segment elevation myocardial infarction. Am Heart J 2012;164:473-80.e5.

20. Wu E, Ortiz JT, Tejedor P, et al. Infarct size by contrast enhanced cardiac magnetic resonance is a stronger predictor of outcomes than left ventricular ejection fraction or end-systolic volume index: prospective cohort study. Heart 2008;94:730-6.

21. Atar D, Petzelbauer P, Schwitter J, et al. Effect of intravenous FX06 as an adjunct to primary percutaneous coronary intervention for acute ST-segment elevation myocardial infarction results of the F.I.R.E. (Efficacy of FX06 in the Prevention of Myocardial Reperfusion Injury) trial. J Am Coll Cardiol 2009;53:720-9.

22. Randomized trial of intravenous atenolol among 16027 cases of suspected acute myocardial infarction: ISIS-1: First International Study of Infarct Survival Collaborative Group. Lancet 1986;2:57-66.

23. Ibanez B, Cimmino G, Prat-González S, et al. The cardioprotection granted by metoprolol is restricted to its administration prior to coronary reperfusion. Int J Cardiol 2011;147:428-32.

24. Ibanez B, Prat-Gonzalez S, Speidl WS, et al. Early metoprolol administration before coronary reperfusion results in increased myocardial salvage: analysis of ischemic myocardium at risk using cardiac magnetic resonance. Circulation 2007;115:2909-16.

25. Pizarro G, Fernandez-Friera L, Fuster V, et al. Long term benefit of early pre-reperfusion metoprolol administration in patients with acute myocardial infarction: results from the METOCARD-CNIC trial. J Am Coll Cardiol 2014;63:2356-62. 




\section{Effects of chronic beta-blocker treatment on admission haemodynamics in STEMI patients treated with Primary Angioplasty.}

European Heart Journal: Acute Cardiovascular Care. 2017.

Epub ahead of print.

Vincent Roolvink, Veemal Hemradj, Jan Paul Ottervanger, Arnoud van 't Hof, Jan-Henk Dambrink, Marcel Gosselink, Elvin Kedhi, Harry Suryapranata. 


\section{ABSTRACT}

\section{Background}

The association between chronic beta-blocker treatment and haemodynamics at admission in patients with ST-elevation myocardial infarction (STEMI) treated by primary percutaneous coronary intervention (PPCI) is not well studied. We investigated the impact of chronic beta-blocker treatment on the risk of cardiogenic shock (CS) and pre-shock at admission in patients with STEMI, treated by PPCI.

\section{Methods and results}

A total of 4907 patients with STEMI treated with $\mathrm{PPCl}$, were included in the study. 1148 patients (23.3\%) were on chronic beta-blocker treatment. CS was observed in 264 patients (5.3\%). Pre-shock was defined as a Shock Index (SI, the ratio of heart rate and systolic blood pressure) $\geq 0.7$ and was observed in 1022 patients (20.8\%). The risk of CS in patients with chronic beta-blocker treatment was not increased (adjusted HR 0.97, 95\% Cl $0.65-1.46$, $\mathrm{p}=0.90$ ). Chronic beta-blocker treatment was also not associated with an increased risk of pre-shock (adjusted HR 0.86, 95\% Cl $0.68-1.07, p=0.19$ ). Also, after propensity score matched analysis, there was no increased risk of CS or pre-shock in patients with chronic beta-blocker treatment (respectively HR 0.97, 95\% CI $0.61-1.51, p=0.88$ and HR 0.82, $95 \% \mathrm{Cl} 0.65-1.06, p=0.12)$

\section{Conclusion}

In STEMI, chronic beta-blocker treatment is not associated with an increased risk of cardiogenic shock or pre-shock. 


\section{INTRODUCTION}

Beta-blockers are widely used, with several indications in the treatment of cardiovascular disease, including stable angina, hypertension, arrhythmias and heart failure. Apart from the favorable effects, beta-blockers may have negative effects on haemodynamics (1). In the acute phase of STEMI, left ventricular function may be severely depressed, leading to increased risk of heart failure and mortality (2). There has been concern about early betablocker use in patients with STEMI (1). However, several studies suggested beneficial effects of early administration of beta-blockers in patients with STEMI (3-5). Recently published data showed that early beta-blocker administration did not result in increased CS at admission (6). However, the effect of chronic beta-blocker treatment on admission hemodynamics in STEMI is still unclear. We investigated the risk of chronic beta-blocker treatment on either CS or preshock in patients with STEMI, treated by PPCI.

\section{METHODS}

Data for this study are from the prospective cohort of patients with STEMI at the Isala Heart Centre, Zwolle, The Netherlands, from January 2005 to December 2011. To avoid double inclusion, only the first recorded admission for STEMI was included. Patients were diagnosed with STEMI if they had chest pain of $>30$ minutes duration and electrocardiographic changes with ST segment elevation $>2 \mathrm{~mm}$ in at least 2 precordial or $>1 \mathrm{~mm}$ in the limb leads. Prior to the PPCI procedure, all patients received 300-500 mg of aspirin intravenously, a P2Y12 blocker (either $600 \mathrm{mg}$ of Clopidogrel or $180 \mathrm{mg}$ of Ticagrelor), and 5000 International Units of unfractionated heparin. Ischemic time was calculated from symptom onset to first balloon inflation. Patients with OHCA were not in included in this analysis.

\section{Definitions}

The primary endpoint of this study was CS at admission. This was defined as a systolic blood pressure $<90 \mathrm{mmHg}$ for at least 30 minutes, clinical signs of pulmonary congestion and endorgan hypoperfusion (cool extremities, altered mental status, or a urine output of $<30 \mathrm{ml} / \mathrm{h}$ ) (2). The secondary endpoint of this study was pre-shock, which was defined as a Shock Index $\geq 0.7(7,8)$. Shock Index (SI) was defined as the ratio of HR and SBP on hospital admission. Coronary angiographic flow was determined in accord with the classification system of the Thrombolysis in Myocardial Infarction (TIMI) study group. 


\section{STATISTIC}

Statistical analysis was performed with the Statistical Package for the Social Sciences version 20.0 (SPSS Inc., Chicago, IL, US). Continuous data are presented as mean \pm standard deviation or median (interquartile 25 - 75) for non-normal distributed variables; whereas discrete data are given as absolute values and percentages. To define potential confounders, we compared baseline characteristics between patients with and without chronic beta-blocker treatment. We assessed the risk of CS and pre-shock at admission in both patient groups. Stratified analyses were performed to assess the prognostic importance in subgroups and to investigate potential effect modification. To demonstrate the independent predictive value of chronic beta-blocker treatment on CS and pre-shock, multivariable analyses was performed, using a binary logistic regression analysis model, adjusting for age, gender, previous MI, previous $P C l$, previous $C A B G$, hypertension, infarct related vessel ( $L M, L A D, R C X, R C A$ ), multivessel disease (MVD) and year of hospitalization. P value of 0.05 was determined as significant. We also performed a propensity analysis for receiving a beta-blocker. A propensity score matched multivariable analysis was performed to assess the risk of CS and pre-shock in both patient groups.

\section{RESULTS}

A total of 4907 patients were included in the current analysis. A total of 1148 patient $(23.3 \%)$ were on chronic beta-blocker treatment. Baseline characteristics and a comparison between patients who were on chronic beta-blocker treatment and those who were not, are summarized in table 1. In short, patients with pre-admission beta-blocker use were older and more often female. Furthermore, they had more often a history of hypertension or myocardial infarction.

A total of 264 patients (5.3\%) had CS on admission. Differences in baseline variables between patients with and without CS are summarized in table 2. Patients with CS had more often multivessel disease and an occluded infarct-related-vessel (TIMI score pre-PCI of 0-1) and had less often anterior wall location. There was no difference in beta-blocker treatment in patients with and without CS. A total of 1022 patient (20.8\%) were in pre-shock (SI $\geq$ 0.7). Differences between patients with and without pre-shock are summarized in table 3 . There was also no difference in beta blocker treatment in patients with and without $\mathrm{SI} \geq 0.7$. Patients with $\mathrm{SI} \geq 0.7$ had more often diabetes mellitus and anterior infarct location.

After univariable analyses, the risk of CS in patients with chronic beta-blocker was comparable to those without chronic beta-blocker treatment, OR 1.0 (95\% Cl 0.7-1.3). Also, 
Table 1 - Baseline characteristics of patients with and without chronic beta-blocker treatment

\begin{tabular}{|c|c|c|c|}
\hline & $\begin{array}{l}\text { Chronic beta-blockers } \\
\text { treatment } \\
(n=1148)\end{array}$ & $\begin{array}{l}\text { No Chronic Beta blocker } \\
\text { treatment }(n=3759)\end{array}$ & p-value \\
\hline Age, years (mean $\pm S D)$ & $68.4 \pm 11.8$ & $62.6 \pm 12.9$ & $<0.001$ \\
\hline Female (\%) & 35.1 & 26.8 & $<0.001$ \\
\hline \multicolumn{4}{|l|}{ Risk factors } \\
\hline Diabetes (\%) & 18.4 & 9.9 & $<0.001$ \\
\hline Hypertension (\%) & 72.5 & 26.0 & $<0.001$ \\
\hline Smoking (\%) & 27.6 & 43.5 & $<0.001$ \\
\hline Dyslipidemia (\%) & 37.0 & 16.4 & $<0.001$ \\
\hline Family History (\%) & 35.4 & 39.0 & 0.03 \\
\hline \multicolumn{4}{|l|}{ History } \\
\hline Previous MI (\%) & 21.4 & 3.9 & $<0.001$ \\
\hline Previous PCI (\%) & 19.6 & 3.7 & $<0.001$ \\
\hline Previous CABG (\%) & 8.7 & 1.9 & $<0.001$ \\
\hline Previous CVA (\%) & 5.7 & 2.4 & $<0.001$ \\
\hline \multicolumn{4}{|l|}{ Medication before admission } \\
\hline Beta-blocker (\%) & 100.0 & 0 & - \\
\hline ACE-inhibitor (\%) & 28.6 & 8.4 & $<0.001$ \\
\hline Calcium antagonist (\%) & 20.9 & 6.1 & $<0.001$ \\
\hline \multicolumn{4}{|l|}{ Hemodynamics on admission } \\
\hline Systolic BP & $133 \pm 27$ & $132 \pm 25$ & 0.32 \\
\hline Heart rate & $75 \pm 19$ & $76 \pm 18$ & 0.17 \\
\hline Cardiogenic shock (\%) & 5.3 & 5.4 & 0.94 \\
\hline Shock Index $\geq 0.7$ (\%) & 20.4 & 21.0 & 0.70 \\
\hline \multicolumn{4}{|l|}{ Lab results on admission } \\
\hline $\mathrm{Hb}, \mathrm{mmol} / \mathrm{L}$ & $8.5 \pm 1.0$ & $8.8 \pm 1.0$ & $<0.001$ \\
\hline Glucose, mmol/L & $9.3 \pm 3.6$ & $9.0 \pm 3.3$ & 0.002 \\
\hline Kreatinine, mmol/L & $103 \pm 73$ & $87 \pm 29$ & $<0.001$ \\
\hline Anterior location (\%) & 40.2 & 42.0 & 0.29 \\
\hline Ischemic time $>2$ hours (\%) & 90.0 & 88.8 & 0.35 \\
\hline \multicolumn{4}{|l|}{ Angiographic data } \\
\hline Multivessel disease (\%) & 57.4 & 45.9 & $<0.001$ \\
\hline TIMI pre 0-1 (\%) & 63.0 & 63.2 & 0.90 \\
\hline
\end{tabular}

the risk of pre-shock was identical in patients with chronic beta-blocker treatment, OR 1.0 (95\% Cl 0.8-1.1). Results of stratified analyses are summarized in figure 1 and 2 . There was no subgroup of patients with chronic beta-blocker treatment with increased risk of CS. In patients with previous CABG, chronic beta-blocker treatment was associated with a reduced risk of CS. However, this concerned a very small group of patients. There was no subgroup 
Table 2 - Baseline characteristics of patients with and without cardiogenic shock on admission

\begin{tabular}{|c|c|c|c|}
\hline & $\begin{array}{c}\text { No CS } \\
(n=4643)\end{array}$ & $\begin{array}{c}\text { CS } \\
(n=264)\end{array}$ & p-value \\
\hline Age, years (mean $\pm S D$ ) & $63.8 \pm 12.9$ & $65.1 \pm 12.6$ & 0.11 \\
\hline Female (\%) & 28.6 & 31.8 & 0.26 \\
\hline \multicolumn{4}{|l|}{ Risk factors } \\
\hline Diabetes (\%) & 11.9 & 12.1 & 0.92 \\
\hline Hypertension (\%) & 37.1 & 33.0 & 0.19 \\
\hline Smoking (\%) & 39.6 & 44.1 & 0.15 \\
\hline Dyslipidemia (\%) & 21.6 & 15.2 & 0.01 \\
\hline Family History (\%) & 38.6 & 30.8 & 0.01 \\
\hline \multicolumn{4}{|l|}{ History } \\
\hline Previous MI (\%) & 8.1 & 7.2 & 0.72 \\
\hline Previous $\mathrm{PCl}(\%)$ & 7.4 & 8.0 & 0.71 \\
\hline Previous CABG (\%) & 3.4 & 4.2 & 0.48 \\
\hline Previous CVA (\%) & 3.1 & 4.2 & 0.36 \\
\hline \multicolumn{4}{|l|}{ Medication before admission } \\
\hline Beta-blocker (\%) & 23.4 & 23.1 & 0.94 \\
\hline ACE-inhibitor (\%) & 12.9 & 15.9 & 0.15 \\
\hline Calcium antagonist (\%) & 9.4 & 11.0 & 0.38 \\
\hline \multicolumn{4}{|l|}{ Hemodynamics on admission } \\
\hline Systolic BP & $135 \pm 23$ & $80 \pm 11$ & $<0.001$ \\
\hline Heart rate & $76 \pm 18$ & $73 \pm 28$ & 0.009 \\
\hline Shock Index $\geq 0.7$ (\%) & 18.3 & 65.9 & $<0.001$ \\
\hline \multicolumn{4}{|l|}{ Lab results on admission } \\
\hline $\mathrm{Hb}, \mathrm{mmol} / \mathrm{L}$ & $8.7 \pm 0.9$ & $8.3 \pm 1.2$ & $<0.001$ \\
\hline Glucose, $\mathrm{mmol} / \mathrm{L}$ & $8.9 \pm 3.1$ & $11.4 \pm 5.0$ & $<0.001$ \\
\hline Kreatinine, mmol/L & $89 \pm 41$ & $112 \pm 70$ & $<0.001$ \\
\hline Anterior location (\%) & 42.4 & 27.6 & $<0.001$ \\
\hline Ischemic time $>2$ hours (\%) & 89.3 & 83.1 & 0.01 \\
\hline \multicolumn{4}{|l|}{ Angiographic data } \\
\hline Multivessel disease (\%) & 48.1 & 55.2 & 0.03 \\
\hline TIMI pre 0-1 (\%) & 62.7 & 71.8 & 0.008 \\
\hline
\end{tabular}

of patients with chronic beta-blocker treatment with increased or reduced risk of pre-shock. Multivariable analyses was performed to adjust for potential confounders. After adjusting for age, gender, previous $\mathrm{MI}$, previous $\mathrm{PCl}$, previous $\mathrm{CABG}$, hypertension, infarct related vessel, MVD and year of hospitalization, there was no impact of chronic beta-blocker treatment on the risk of $\mathrm{CS}$ at admission ( $\mathrm{HR} 0.97,95 \% \mathrm{Cl} 0.65-1.46, \mathrm{p}=0.90$ ). Chronic beta-blocker treatment was also not associated with a reduced or increased risk of pre-shock (HR 0.86, 
Table 3 - Baseline characteristics of patients with and without pre-shock ( $\mathrm{SI} \geq 0.7)$ on admission

\begin{tabular}{|c|c|c|c|}
\hline & $\begin{array}{l}\text { Shock Index }<0.7 \\
\qquad(n=3885)\end{array}$ & $\begin{array}{l}\text { Shock Index } \geq 0.7 \\
\quad(n=1022)\end{array}$ & $p$-value \\
\hline Age, years (mean $\pm S D)$ & $63.9 \pm 12.7$ & $63.7 \pm 13.4$ & 0.74 \\
\hline Female (\%) & 28.2 & 30.0 & 0.07 \\
\hline \multicolumn{4}{|l|}{ Risk factors } \\
\hline Diabetes (\%) & 11.1 & 14.8 & 0.002 \\
\hline Hypertension (\%) & 37.7 & 33.9 & 0.02 \\
\hline Smoking (\%) & 39.6 & 40.6 & 0.58 \\
\hline Dyslipidemia (\%) & 21.6 & 20.1 & 0.32 \\
\hline Family History (\%) & 38.8 & 35.7 & 0.07 \\
\hline \multicolumn{4}{|l|}{ History } \\
\hline Previous MI (\%) & 7.6 & 9.5 & 0.05 \\
\hline Previous PCI (\%) & 7.3 & 7.7 & 0.63 \\
\hline Previous CABG (\%) & 3.1 & 4.7 & 0.02 \\
\hline Previous CVA (\%) & 2.8 & 4.6 & 0.005 \\
\hline \multicolumn{4}{|l|}{ Medication before admission } \\
\hline Beta-blocker (\%) & 23.5 & 22.9 & 0.70 \\
\hline ACE-inhibitor (\%) & 12.4 & 15.7 & 0.006 \\
\hline Calcium antagonist $\mathrm{v}$ & 9.4 & 9.8 & 0.67 \\
\hline \multicolumn{4}{|l|}{ Hemodynamics on admission } \\
\hline Systolic BP & $137 \pm 24$ & $112 \pm 22$ & $<0.001$ \\
\hline Heart rate & $70 \pm 14$ & $96 \pm 20$ & $<0.001$ \\
\hline Cardiogenic shock (\%) & 2.3 & 17.0 & $<0.001$ \\
\hline \multicolumn{4}{|l|}{ Lab results on admission } \\
\hline $\mathrm{Hb}, \mathrm{mmol} / \mathrm{L}$ & $8.7 \pm 0.9$ & $8.6 \pm 1.0$ & 0.008 \\
\hline Glucose, mmol/L & $8.7 \pm 2.9$ & $10.1 \pm 4.2$ & $<0.001$ \\
\hline Kreatinine, mmol/L & $89 \pm 44$ & $94 \pm 42$ & 0.001 \\
\hline Anterior location (\%) & 40.4 & 46.5 & 0.001 \\
\hline Ischemic time $>2$ hours (\%) & 89.2 & 88.4 & 0.52 \\
\hline \multicolumn{4}{|l|}{ Angiographic data } \\
\hline Multivessel disease (\%) & 47.8 & 51.0 & 0.07 \\
\hline TIMI pre 0-1 (\%) & 63.5 & 61.7 & 0.37 \\
\hline
\end{tabular}

$95 \% \mathrm{Cl} 0.68-1.07, \mathrm{p}=0.19)$. After propensity score matched multivariable analysis, there was still no impact of chronic beta-blocker treatment on the risk of $\mathrm{CS}$ or pre-shock at admission (respectively HR $0.97,95 \% \mathrm{Cl} 0.61-1.51, p=0.88$ and HR $0.82,95 \% \mathrm{Cl} 0.65-1.06$, $p=0.12)$ 


\section{DISCUSSION}

In this large registry of patients with STEMI treated by $\mathrm{PPCl}$, there was no evidence for deteriorated hemodynamics on admission in patients on chronic beta-blocker treatment. In our study, anterior myocardial infarction was significantly less present in patients with CS. However, the presence of inferior myocardial infarction was significantly higher in patients with CS versus without CS (respectively $49.4 \%$ versus 38.9\%, $p=0.001$ ), suggesting RV involvement or AV-nodal block or vasovagal reactions. This also explains the lower heart rate in CS patients versus patients without CS. Although in general patients with inferior wall myocardial infarction have a better prognosis, those who have hypotension and RV involvement may have a poor prognosis (9).

\section{COMPARISON WITH PREVIOUS STUDIES}

Beta-blockers reduce mortality when administrated after myocardial infarction $(10,11)$. They also decrease the incidence of recurrent $\mathrm{MI}$, recurrent ischemia and life-threating arrhythmias and improve left ventricular remodeling. Therefore, use of beta-blockers constitutes a class I indication in clinical guidelines (12-14). However, the effects of early beta-blocker administration on admission hemodynamics in STEMI patients, had been studied poorly until recently. In the COMMIT trial (1), the prevalence of recurrent MI or ventricular fibrillation was significantly lower in patients treated with beta-blockers before admission. However, this was counterbalanced by a $1.1 \%$ increase in cardiogenic shock. Based on this trial, it was suggested that it might be more prudent to start beta-blockers only after a patient's hemodynamic condition has stabilized after AMI. However, in COMMIT reperfusion was performed with thrombolytics, and patients scheduled for $\mathrm{PCI}$ were even excluded. Furthermore, the dose of beta blocker may have been too high in COMMIT, especially in selected patients with low blood pressure. An older study suggested reduced risk of mortality in patients taking beta-blockers before admission, but this study was performed in patients who were not treated by PPCI (15).

In the era of PPCI the effect of beta-blocker treatment before admission has been analyzed in a limited number of studies $(3,6,16,17)$. In an observational study, STEMI patients treated by PPCI showed that elevated admission heart rate was associated with long-term increase of all-cause mortality and beta-blocker therapy reduced mortality in patients with elevated admission heart rate (4). The METOCARD-CNIC trial used the same beta-blocker scheme as in the COMMIT trial in anterior STEMI during transportation to the $\mathrm{PCI}$ center. They showed that early intravenous beta-blocker reduced infarct size and improved left ventricular ejection fraction, with no excess of adverse events or CS (17). In the recently published Early-BAMI 
trial (6), early metoprolol administration did not reduce infarct size, but also did not increase adverse events such as CS. However, these trials focused on the effect of beta-blockers on infarct size and LV function. Our study focused on chronic beta-blocker treatment and its effect on admission haemodynamics in STEMI patients.

\section{STRENGTHS AND LIMITATIONS}

We studied the independent prognostic importance of chronic beta blocker treatment on the risk of CS and pre-shock at admission in STEMI patients. The strength of this study is the large STEMI cohort and the addition of a propensity score matched analysis. Also, the cohort studied, is comparable to other STEMI cohorts.

Our study has, however, also some limitations. Our study was a retrospective cohort study. A major limitation is that we had no data about LV-function in most patient. We had no data on use of inotropics before admission, although this medication is rarely given in the ambulance. We had also no data on type, dose and duration of beta-blocker treatment before admission.

\section{CLINICAL IMPLICATIONS}

Beta-blockers are drugs with multiple actions on the heart. Blockade of $\beta 1$ receptors results in reduction of myocardial oxygen demand by reduction of heart rate and myocardial contractility. In the context of acute myocardial infarction, which represents a state of reduced oxygen supply to the affected portion of the heart, these effects may be beneficial. But there is debate whether pre-reperfusion administration of intravenous $\beta$-blockers may reduce infarct size as compared with post-reperfusion administration, and whether this will be safe, without increasing risk of cardiogenic shock. In the current era of primary PCl, the METOCARD-CNIC trial showed reduced infarct size and increased LV ejection fraction in anterior wall STEMI patients without signs of heart failure treated with early intravenous metoprolol $(5,17)$. However, this single study had a limited sample size, was not blinded, not placebo controlled, and included a selected patient group. The recently published Early BAMI trial has a larger sample size in which $\beta$ - blocker administration before primary PCI was studied in all patients with STEMI, with a double blinded, placebo-controlled design (6). This trial did not show reduction in infarction size but did reduce the incidence of malignant arrhythmias in the acute phase and was not associated with an increase in adverse events. Our study shows that chronic beta-blocker use did not increase the incidence of CS or pre-shock at admission in STEMI patients. These results support the Early BAMI with respect to hemodynamics. 


\section{CONCLUSION}

In STEMI treated by PPCl, chronic beta-blocker treatment is not associated with an increased risk of CS or pre-shock at admission. 


\section{REFERENCES.}

1. Chen $Z M$, Pan $H C$, Chen $Y P$, Peto $R$, Collins $R$, Jiang $L X$, et al. Early intravenous then oral metoprolol in 45,852 patients with acute myocardial infarction: randomised placebo-controlled trial. Lancet. 2005;366(9497):1622-32.

2. Hochman JS. Cardiogenic shock complicating acute myocardial infarction: Expanding the paradigm. Vol. 107, Circulation. 2003;107(24):2998-3002.

3. Hirschl MM, Wollmann CG, Erhart F, Brunner W, Pfeffel F, Gattermeier M, et al. Benefit of immediate beta-blocker therapy on mortality in patients with ST-segment elevation myocardial infarction. Crit Care Med. 2013;41(6):1396-404.

4. Noman A, Balasubramaniam K, Das R, Ang D, Kunadian V, Ivanauskiene T, et al. Admission heart rate predicts mortality following primary percutaneous coronary intervention for ST-elevation myocardial infarction: An observational study. Cardiovasc Ther. 2013;31(6):363-9.

5. Pizarro G, Fernández-Friera L, Fuster V, Fernández-Jiménez R, García Ruiz JM, García Álvarez A, et al. Long-term benefit of early pre-reperfusion metoprolol administration in patients with acute myocardial infarction: Results from the Metocard-CNIC trial (Effect of Metoprolol in Cardioprotection during an Acute Myocardial Infarction). J Am Coll Cardiol. 2014;63(22):2356-62.

6. Roolvink V, Ibáñez B, Ottervanger JP, Pizarro G, van Royen N, Mateos A, et al. Early Intravenous Beta-Blockers in Patients With ST-Segment Elevation Myocardial Infarction Before Primary Percutaneous Coronary Intervention. J Am Coll Cardiol. 2016;67(23):2705-15.

7. Spyridopoulos I, Noman A, Ahmed JM, Das R, Edwards R, Purcell l, et al. Shock-index as a novel predictor of long-term outcome following primary percutaneous coronary intervention. Eur Hear J Acute Cardiovasc Care. 2015;4(3):270-7.

8. Hemradj V V., Ottervanger JP, de Boer MJ, Suryapranata H. Shock Index More Sensitive Than Cardiogenic Shock in ST-Elevation Myocardial Infarction Treated by Primary Percutaneous Coronary Intervention. Circ J. 2016;81:199-205.

9. Zehender M, Kasper W, Kauder E, Schonthaler M, Geibel A, Olschewski M, et al. Right ventricular infarction as an independent predictor of prognosis after acute inferior myocardial infarction. $N$ Engl J Med. 1993;328(14):981-8.

10. Committee TS. Metoprolol in acute myocardial infarction (MIAMI). A randomized placebo controlled international trial. The MIAMI Trial Research Group. Eur Heart J. 1985;6(3):199-226.

11. ISIS Study Group. Randomised trial of intravenous atenolol among 16027 cases of suspected acute myocardial infarction: ISIS-1. First International Study of Infarct Survival Collaborative Group. Lancet. 1986;2(8498):57-66.

12. Domanski MJ, Zipes DP, Schron E. Treatment of Sudden Cardiac Death. Circulation. 1997 Jun 17;95(12):2694 LP-2699

13. López-Sendó J, Swedberg K, McMurray J, Tamargo J, Maggioni AP, Dargie H, et al. Expert consensus document on $\beta$-adrenergic receptor blockers. Eur Heart J. 2004;25(15):1341- 62.

14. Steg PG, James SK, Atar D, Badano LP, Lundqvist CB, Borger MA, et al. ESC Guidelines for the management of acute myocardial infarction in patients presenting with ST-segment elevation. Eur Heart J. 2012;33(20):2569-619.

15. Nidorf SM, Parsons RW, Thompson PL, Jamrozik KD, Hobbs MS. Reduced risk of death at 28 days in patients taking a beta blocker before admission to hospital with myocardial infarction. BMJ. 1990;300(6717):71-4.

16. Hanada K, Higuma T, Nishizaki F, Sukekawa T, Yokota T, Yamada M, et al. Randomized Study on the Efficacy and Safety of Landiolol, an Ultra-Short-Acting B1-Adrenergic Blocker, in Patients 
With Acute Myocardial Infarction Undergoing Primary Percutaneous Coronary Intervention. Circ J. 2012;76(2):439-45.

17. Ibanez B, Macaya C, Sánchez-Brunete V, Pizarro G, Fernández-Friera L, Mateos A, et al. Effect of Early Metoprolol on Infarct Size in ST-Segment Elevation Myocardial Infarction Patients Undergoing Primary PCl: The METOCARD-CNIC Trial. Circulation. 2013; Oct 1;128(14):1495-503 




\section{Early Intravenous Beta-Blockers in Patients With ST-Segment Elevation Myocardial Infarction Before Primary Percutaneous Coronary Intervention. EARLY-BAMI Investigators.}

J Am Coll Cardiol. 2016 Jun 14;67(23):2705-15

Vincent Roolvink, Borja Ibanez, Jan Paul Ottervanger,

Gonzalo Pizarro, Niels van Royen, Alonso Mateos, Jan-Henk E. Dambrink, Noemi Escalera, Erik Lipsic,

Agustín Albarran, Antonio Fernández-Ortiz, Francisco Fernández-Avilés, Javier Goicolea, Javier Botas, Wouter Remkes, Victoria Hernandez-Jaras, Elvin Kedhi, José L Zamorano, Felipe Navarro, Fernando Alfonso, Alberto García-Lledó, Joaquin Alonso, Maarten van Leeuwen, Robin Nijveldt, Sonja Postma, Evelien Kolkman, Marcel Gosselink,

Bart de Smet, Saman Rasoul, Jan J. Piek, Valentin Fuster, Arnoud W.J. van 't Hof. On behalf of the EARLY BAMI investigators. 


\section{ABSTRACT}

\section{Background}

The impact of i.v. beta-blockers before primary $\mathrm{PCI}$ (pPCl)on infarct size and clinical outcomes is not well established, with only one prior study showing benefit of early i.v. metoprolol before $\mathrm{pPCl}$. The Early- Beta-blocker Administration before primary $\mathrm{PCI}$ in patients with ST-elevation Myocardial Infarction (Early-BAMI) trial, is the first double-blinded, placebocontrolled international multicenter study testing the effect of early i.v. $\beta$-blockers before $\mathrm{PPCl}$ in a general STEMI population.

\section{Methods}

STEMI patients presenting $<12 \mathrm{~h}$ from symptom onset, Killip I-II, without AV block, were 1:1 randomized to i.v. metoprolol ( $2 \times 5 \mathrm{mg}$ bolus) or matched placebo before primary $\mathrm{PCI}$. Primary endpoint was myocardial infarct size as assessed by magnetic resonance imaging (MRI) at 30 days. Secondary endpoints were enzymatic infarct size and incidence of ventricular arrhythmias. Safety endpoints included symptomatic bradycardia, symptomatic hypotension, and cardiogenic shock.

\section{Results}

A total of 683patients (mean age was $62 \pm 12$ years (75\% male) were randomized to metoprolol $(n=336)$ or placebo $(n=346)$. MRI was performed in 342 patients $(54,8 \%)$. No significant differences in baseline characteristics were observed. Infarct size ( $\%$ of LV) by MRI did not differ between the metoprolol $(15.3 \pm 11.0 \%)$ and placebo group $(14.9 \pm 11.5 \%$ $\mathrm{p}=0.616)$. Peak and area under the creatine kinase (CK) curve did not differ between both groups. Left ventricular ejection fraction by MRI was $51.0 \pm 10.9 \%$ in the metoprolol group and $51.6 \pm 10.8 \%$ in the placebo group, $p=0.68$. The incidence of malignant arrhythmias was $3.6 \%$ in the metoprolol group vs $6.9 \%$ in placebo $p=0.050$. The incidence of adverse events was not different between groups.

\section{Conclusion}

In a non-restricted STEMI population, early intravenous metoprolol before $\mathrm{pPCl}$, was not associated with a reduction in infarct size. Metoprolol reduced the incidence of malignant arrhythmias in the acute phase and was not associated with an increase in adverse events. 


\section{BACKGROUND}

Despite advances in the care for patients with ST-elevation myocardial infarction (STEMI), mortality in these patients remains relative high, especially in an all comer population. (1) Although early diagnosis and treatment have improved outcome of these patients, additional interventions early after onset of ischemia might further improve outcome. In the clinical guidelines, treatment with $\beta$-blockers for STEMI patients is recommended, (2) although the evidence of mortality reduction with $\beta$-blockers after reperfusion therapy is limited. (2-4) Whether administration before reperfusion improves clinical outcome or reduces myocardial infarct size is less clear. Experimental studies have conflicting results whether $\beta$-blockers decrease the extent of myocardial necrosis (4-6). In clinical studies in STEMI, the effect of early $\beta$-blockade was mostly studied in the prereperfusion era, with inconclusive results. (7-10) In the era of thrombolysis, 2 randomized controlled trials testing the effect of $\beta$-blockers in STEMI showed no reduction in mortality with $\beta$-blocker treatment. $(11,12)$ In patients treated by primary percutaneous coronary intervention ( $\mathrm{pPCl}$ ), only 2 randomized controlled trials studied the effect of early $\beta$-blocker treatment. Hanada et al observed in a small study $(n=96)$ that continuous intravenous landiolol immediately after primary $\mathrm{PCl}$ was associated with an improvement of left ventricular (LV) function. (13) The Effect of Metoprolol in Cardioprotection During an Acute Myocardial Infarction (METOCARD-CNIC) trial $(n=220)$ showed that intravenous metoprolol administrated before primary $\mathrm{PCI}$ reduces infarct size and preserved LV function. (14-16) In the latter trial however, only patients with an anterior location of STEMI were included, and the trial was neither blinded nor placebo controlled. We present the results of the Early-BAMI trial, the first double-blinded, placebo-controlled multicenter international study, assessing the effect of early i.v. $\beta$-blocker therapy before pPCI in a less restricted STEMI population. (17)

\section{METHODS}

The primary objective of the EARLY-BAMI trial (EudraCT no.: 2010-023394-19.) was to assess the effect of early, prehospital pre-reperfusion administration of intravenous metoprolol on myocardial infarct size in patients with STEMI eligible for primary $\mathrm{PCl}$. The design of the study has previously been published. (17) The study was approved by the medical ethical committees of the participating hospitals. It concerns a multicenter, multinational, doubleblind, placebo-controlled randomized clinical trial. A total of $5 \mathrm{PCl}$ centers and 3 ambulance services in The Netherlands and $9 \mathrm{PCl}$ centers and 1 ambulance service in Spain enrolled patients. All centers had a long-standing experience in the pre-hospital diagnosis, triage and treatment of STEMI patients in the ambulance and were part of a STEMI network. The trial was conducted with a research grant of the Dutch Heart Foundation (Utrecht, Netherlands, 
no. 2010B125) and an unrestricted grant of Medtronic Inc. (Heerlen, The Netherlands) for additional analyses.

\section{STUDY PROTOCOL}

Patients aged $>18$ years with symptoms of acute STEMI for $>30$ minutes but $<12$ hours and ST elevation $>1 \mathrm{mV}$ in 2 adjacent ECG leads or new left bundle branch block (LBBB) were eligible for enrollment. The diagnosis of STEMI was made by the ambulance medical personnel. Electrocardiogram transmission to a physician at the $\mathrm{PCl}$ center could be performed to allow confirmation of the diagnosis. After the diagnosis of STEMI in the ambulance, medical treatment in all patients occurred as per current guidelines with the administration of $500 \mathrm{mg}$ of aspirin intravenously, $600 \mathrm{mg}$ Clopidogrel or $180 \mathrm{mg}$ of Ticagrelor orally, and 5,000 International Units of unfractionated heparin intravenously. Exclusion criteria were Killip class III and IV, systolic blood pressure $<100 \mathrm{mmHg}$, heart rate $<60 \mathrm{bpm}$, type II and III atrioventricular block, history of previous MI, known asthma bronchiale, pacemaker or internal cardiac defibrillator (ICD) implantation (no MRI possible), pregnancy or breastfeeding or inability to provide informed consent. If patients fulfilled the inclusion/exclusion criteria, verbal informed consent was obtained. The trained ambulance paramedic completed the administration / enrolment procedure. After informed consent, a blinded study medication box was opened. This box contained 2 vials with metoprolol $5 \mathrm{mg}$ or matched placebo and was labeled with a number that corresponded with the randomization list. Randomization took place without stratification and in blocks of 4 . The first bolus of study medication was given in the ambulance, the second bolus in the $\mathrm{PCI}$ hospital at the catheterization laboratory before the $\mathrm{PCl}$ procedure only if systolic blood pressure was $>100 \mathrm{mmHg}$ and heart rate $>60 \mathrm{bpm}$. Given that in the COMMIT CC2 trial (12), 15mg of metoprolol administration in a short interval was associated with a slight increase in cardiogenic shock (although this was restricted to Killip III patients), the reference ethics committee suggested to reduce the dose to $10 \mathrm{mg}$ separated into two $5 \mathrm{mg}$ boluses: the first $5 \mathrm{mg}$ bolus during ambulance transit, and the second $5 \mathrm{mg}$ bolus on arrival at the cath lab (i.e. immediately before initiating the $\mathrm{PCI}$ ). The results of the METOCARD-CNIC trial (using $15 \mathrm{mg}$ metoprolol) were not known at the time of the study design. Patients participating in the trial were treated during hospital admission and thereafter according to current guidelines. During $\mathrm{PCl}$, the use of thrombus aspiration and the use of glycoprotein IIb-Illa inhibitors was left at the discretion of the operator. In addition, stenting was performed with a second-generation drug-eluting stent. After $\mathrm{PCl}$, patients received detailed written study information in which the protocol and the MRI follow up was explained in more detail, where after written informed consent was obtained. All patients were planned to receive oral metoprolol within 12 hours after $\mathrm{PCl}$, according to current guidelines, during hospitalization. At discharge, all patients received 
oral metoprolol at a dose recommended by their treating physician. Follow-up included visits at the outpatient clinic at each center and allowed us to obtain data for follow-up.

\section{END POINTS}

The primary end point was myocardial infarct size (\% infarcted myocardium, \% of LV) as measured by MRI at 30 days ( \pm 10 days). The secondary efficacy end points were peak creatine kinase (CK), peak CK-MB, troponin at 24 hours, and area under the CK and CK-MB curve during the first 24 hours, residual ST deviation 1 hour after PCI/coronary angiogram, ventricular arrhythmias requiring defibrillation during transportation and hospitalization and major adverse cardiac events (MACE), defined as cardiac death, nonfatal reinfarction, or target vessel revascularization at 30 days. The secondary safety end points include symptomatic bradycardia, symptomatic hypotension, and cardiogenic shock. The following subgroups were prespecified for analysis: anterior versus nonanterior infarctions, patients presenting $<6$ hours after symptom onset versus patients presenting $>6$ hours, and occluded (Thrombolysis In Myocardial Infarction (TIMI) 0 and 1 flow) infarct-related vessel at time of PCI versus open (TIMI 2 and 3 flow) infarct-related vessel.

\section{STATISTICAL METHODS}

\section{Sample size calculation.}

Initially, the study was designed and initiated with enzymatic infarct size as primary end point. However, after inclusion of 164 patients, the primary end point was changed into a MRI based end point (at 3 July 2013), which was approved by the steering committee and the medical ethical committee. The original primary outcome measure was enzymatic infarct size measured by cardiac troponin $\mathrm{T}$, and required 770 patients, based on the assumption that pre-hospital administration of $2 \times 5 \mathrm{mg}$ metoprolol iv would give a relative $20 \%$ reduction in infarct size. (alpha $=0.05$, power 80\%, mean troponin T 3.34 ng/L, SD:3.30). This original primary outcome, became a secondary outcome after the change in the protocol. The change in the primary outcome was primarily made in order to reduce the necessary sample size and a time limitation of financial funding. Also, infarct size could be studied more precisely with MRI. The change occurred while the investigators were still entirely blinded to trial results, and without any interim analysis performed. The sample size was than determined for the primary end point of the trial by a power analysis with reasonable clinical and statistical assumptions. With an expected infarct size of $28 \%$ (18) in a population under standard treatment (no $\beta$-blockers pre-PCI), we considered a reduction in infarct size from $28 \%$ to $23.5 \%$ clinically relevant. Assuming an SD of the myocardial infarction (MI) size measured by 
MRI equal to $10 \%$, (19) the power analysis indicated a total sample size of 326 patients (163 subjects in each group) was needed to achieve $80 \%$ power with significance level of 0.05 to detect a difference in infarct size.

Patients who died after completing the MRI study were included in the primary outcome analysis. Patients who died before performance of the MRI were not included in the primary outcome analysis; however, they were included in the secondary outcome analysis because death within 1 year is a secondary end point. Statistical analysis was performed with Statistical Analysis System, SAS, version 9.3 and with the Statistical Package for the Social Sciences (SPSS, IBM) version 22.0. Continuous data was expressed as mean \pm SD of mean and categorical data as percentage, unless otherwise denoted. The analysis of variance and the $x 2$ test was appropriately used for continuous and categorical variables, respectively. For quantitative variables data were expressed as mean +/- SD and median with first and third quartiles. Non-normal data were compared by non-parametric methods (Wilcoxon rank-sum test) and normal data by parametric methods. Categorical data were expressed as percentages and compared by Chi Square test (or Fischer Exact test when appropriate). For all analyses, statistical significance was assumed when the 2 -tailed $\mathrm{P}<0.05$.

\section{CARDIAC MRI ANALYSIS}

All MRI studies were performed blinded to treatment allocation and according to a centralized protocol. Dedicated sequences evaluating cardiac function, myocardial edema, myocardial perfusion, and myocardial necrosis/fibrosis were performed. All MRI studies were stored and further analyzed in a central core laboratory at the Centro Nacional de Intervestigaciones Cardiovasculares Carlos III (CNIC) in Madrid, Spain. Analysis of MRI studies were performed in a random manner by expert observers blinded to treatment allocation. Quantification was performed on a separate workstation using a dedicated software package (QMass MR 7.6; Medis, Leiden, the Netherlands). In all MRI studies, the following information was determined: LV volumes, LV function, and myocardial delayed enhancement. Myocardial necrosis was defined by the extent of abnormal delayed enhancement. All measurements were expressed as percentage of the total LV myocardial volume; the absolute MI size was also quantified in grams. All results were given in absolute numbers and indexed by patients' body surface. Differences between the 2 groups was estimated by multivariable linear regression adjusted for the participating hospital center and the stratification variables. 


\section{RESULTS}

Between February 2012 and November 2015, 684 patients were enrolled in 14 participating hospitals and 4 ambulance services in the Netherlands and Spain. In one patient, the box with the study medication was lost during transportation and this patient was excluded from the analysis. The 683 remaining patients were randomized to metoprolol $(n=336)$ or placebo $(n=347)$ before primary $\mathrm{PCl}$. Mean age was $62 \pm 12$ years ( $75 \%$ males). A flow diagram is shown in Figure 1. Baseline characteristics of the study population are presented in Table 1. Although time from onset of complaints till first medical contact was comparable between the two groups, early presenters ( $<6$ hours after complaints onset) were more often present in the metoprolol group. At inclusion (before randomization), mean blood pressure on admission was comparable between the two groups, while mean heart rate was not-significantly lower in the metoprolol group ( 78.6 beats $/ \mathrm{min}$ vs 80.5 beats $/ \mathrm{min}, \mathrm{p}=0.09$ ). A total of 20 patients (2.9\%) were enrolled at the emergency department of the $\mathrm{PCl}$ center, mainly because transportation of the patient to the $\mathrm{PCI}$ center was very short. In these patients, the first study bolus was given as soon as possible at the emergency department, and the second bolus at arrival at the cath lab.

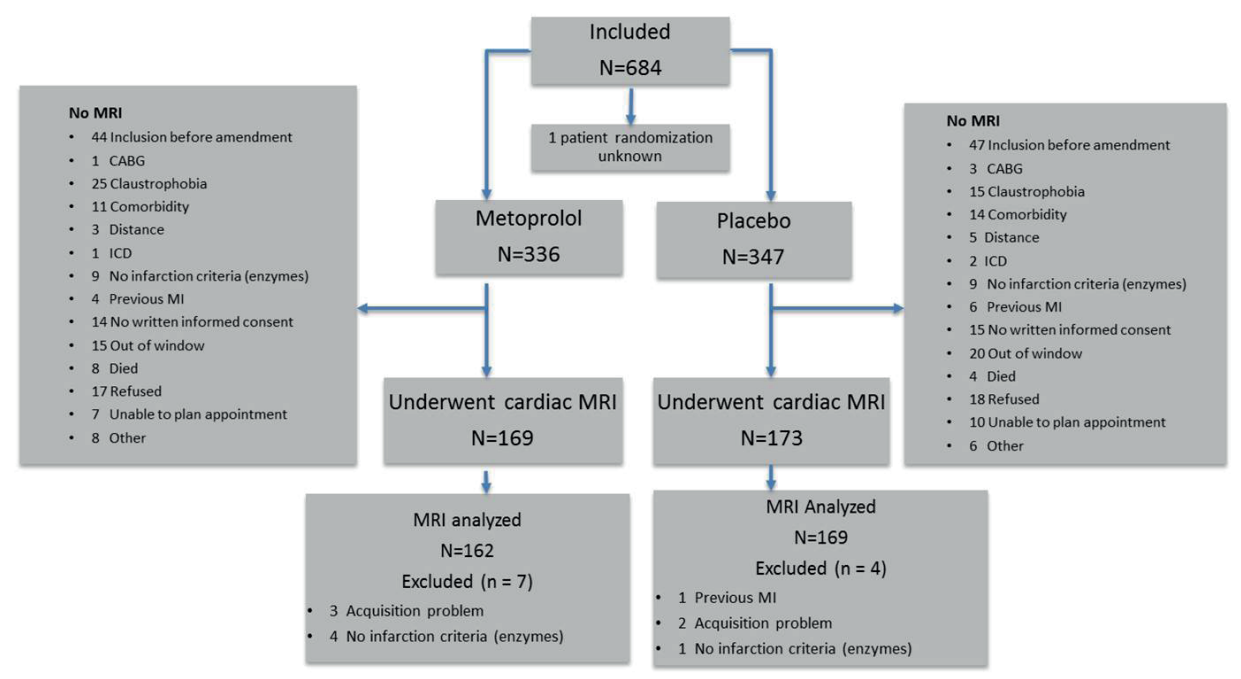

Figure 1 - Diagram of patient flow.

Of the 336 patients allocated to pre-reperfusion metoprolol, $81.1 \%$ received also the second bolus, compared to $86 \%$ in the placebo group $(p=0.08)$. Blood pressure before the second bolus (administered at the cath lab) was not different between groups, while heart rate was lower in the metoprolol group. Coronary angiography was performed in $99 \%$ of patients, similar in the metoprolol and placebo groups. One-vessel disease was observed in $53 \%$ of 
the metoprolol group compared to $59 \%$ of the placebo group $(p=0.06)$. Initial TIMI flow 0 or 1 was demonstrated in $62 \%$ of the patients in the metoprolol group versus $60 \%$ in the

Table 1 - Baseline characteristics of 684 patients with STEMI, randomized to either metoprolol or placebo before primary $\mathrm{PCl}$

\begin{tabular}{|c|c|c|c|c|}
\hline Characteristic & $\begin{array}{l}\text { Metoprolol } \\
(\mathrm{N}=336)\end{array}$ & $\begin{array}{l}\text { Placebo } \\
(\mathrm{N}=347)\end{array}$ & $\begin{array}{c}\text { Total } \\
(\mathrm{N}=684)\end{array}$ & P-value \\
\hline Mean Age (years) $\pm S D$ & $62.39 \pm 12.42$ & $62.46 \pm 12.58$ & $62.42 \pm 12.49$ & 0.882 \\
\hline Female gender & $84 / 336(25.0 \%)$ & $88 / 347(25.4 \%)$ & $172 / 683(25.2 \%)$ & 0.914 \\
\hline Mean length $(\mathrm{cm}) \pm S D$ & $174.3 \pm 10.22$ & $175.2 \pm 9.59$ & $174.8 \pm 9.91$ & 0.327 \\
\hline Mean weight $(\mathrm{kg}) \pm S D$ & $82.82 \pm 16.39$ & $84.71 \pm 16.04$ & $83.78 \pm 16.23$ & 0.102 \\
\hline Mean BMI \pm SD & $27.14 \pm 4.45$ & $27.40 \pm 4.11$ & $27.27 \pm 4.28$ & 0.246 \\
\hline Diabetes & $48 / 335(14.3 \%)$ & $62 / 347(17.9 \%)$ & $110 / 682(16.1 \%)$ & 0.209 \\
\hline Previous hypertension & $135 / 335(40.3 \%)$ & $133 / 344(38.7 \%)$ & $268 / 679(39.5 \%)$ & 0.695 \\
\hline Beta blocker use as home medication & $54 / 298(18.1 \%)$ & $60 / 308(19.5 \%)$ & $114 / 606(18.8 \%)$ & 0.669 \\
\hline Anterior location & $154 / 312(49.4 \%)$ & $166 / 318(52.2 \%)$ & $320 / 630(50.8 \%)$ & 0.677 \\
\hline First medical contact & & & & 0.595 \\
\hline Referring hospital & $19 / 335(5.7 \%)$ & $16 / 347(4.6 \%)$ & $35 / 682(5.1 \%)$ & \\
\hline $\mathrm{PCl}$ center & $8 / 335(2.4 \%)$ & $12 / 347(3.5 \%)$ & $20 / 682(2.9 \%)$ & \\
\hline Ambulance & $308 / 335(91.9 \%)$ & $319 / 347(91.9 \%)$ & $627 / 682(91.9 \%)$ & \\
\hline \multicolumn{5}{|c|}{ Time (minutes) from onset complaints till first medical contact } \\
\hline Mean \pm SD & $135.5 \pm 231.9$ & $147.9 \pm 212.5$ & $141.7 \pm 222.3$ & 0.880 \\
\hline Early presenters (within 6 hours) & $288 / 307(93.8 \%)$ & $277 / 310(89.4 \%)$ & $565 / 617(91.6 \%)$ & 0.046 \\
\hline \multicolumn{5}{|c|}{ Time (minutes) from onset complaints till admission } \\
\hline \multirow[t]{2}{*}{ Mean \pm SD } & $195.5 \pm 262.5$ & $201.6 \pm 262.1$ & $198.6 \pm 262.1$ & 0.755 \\
\hline & $(n=307)$ & $(n=318)$ & $(n=625)$ & \\
\hline \multicolumn{5}{|l|}{ Hemodynamics at admission } \\
\hline Mean Systolic BP $(\mathrm{mm} \mathrm{Hg}) \pm$ SD & $136.4 \pm 22.91$ & $138.7 \pm 26.43$ & $137.6 \pm 24.75$ & 0.384 \\
\hline Mean Diastolic BP $(\mathrm{mm} \mathrm{Hg}) \pm S D$ & $82.25 \pm 14.67$ & $82.83 \pm 16.16$ & $82.54 \pm 15.43$ & 0.702 \\
\hline Mean Heart Rate (beats/min) $\pm S D$ & $74.35 \pm 13.71$ & $78.68 \pm 15.69$ & $76.53 \pm 14.89$ & $<0.001$ \\
\hline Discharge medication & & & & 0.379 \\
\hline ACE-inhibitor & 215/333 (64.6\%) & 209/341 (61.3\%) & $424 / 674(62.9 \%)$ & 0.148 \\
\hline A II blockers & $14 / 333(4.2 \%)$ & $23 / 341(6.7 \%)$ & $37 / 674(5.5 \%)$ & 0.127 \\
\hline Beta Blocker & $260 / 333(78.1 \%)$ & 249/341 (73.0\%) & $249 / 341(73.0 \%)$ & \\
\hline \multicolumn{5}{|l|}{ Angiographic findings } \\
\hline One vessel disease & $175 / 330(53.0 \%)$ & $201 / 339(59.3 \%)$ & $376 / 669(56.2 \%)$ & \\
\hline Two vessel disease & $100 / 330(30.3 \%)$ & $71 / 339(20.9 \%)$ & $171 / 669(25.6 \%)$ & \\
\hline Three vessel disdease & $39 / 330(11.8 \%)$ & $46 / 339(13.6 \%)$ & $85 / 669(12.7 \%)$ & \\
\hline Primairy PCI & $306 / 315(97.1 \%)$ & $306 / 322(95.0 \%)$ & $612 / 637(96.1 \%)$ & 0.164 \\
\hline Additional PCI during admission & $16 / 334(4.8 \%)$ & $15 / 345(4.3 \%)$ & $31 / 679(4.6 \%)$ & 0.782 \\
\hline CABG during admission & $12 / 335(3.6 \%)$ & $24 / 345(7.0 \%)$ & $36 / 680(5.3 \%)$ & 0.049 \\
\hline
\end{tabular}


placebo group ( $p=0.61$ ). Primary PCI was performed in 93\% (metoprolol group) and $92 \%$ (placebo group, $p=0.66$ ), and was successful in $97 \%$ in both groups $(p=0.70)$. Oral metoprolol was initiated within 24 hours in $78 \%$ in the metoprolol group and $73 \%$ of patients in the placebo group $(p=0.13)$.

\section{Primary Endpoint}

MRI was performed in 342 of the 520 patients (66\%) who were included after the change of the primary end point. (67\% in the metoprolol group and $67 \%$ in the placebo group, $\mathrm{p}=0.77$ ). In the 342 patients who had MRI performed, no major differences in baseline characteristics between the treatment groups were present. In the MRI sample size calculation, we accounted for a drop out of $20 \%$. But the actual dropout rate was higher (34\%), so to meet the needed number of MRI, patient recruitment was continued until the needed number of 326 analyzed MRI's was reached. The main reasons why MRI were not performed were claustrophobia, planning out of the time window of one month \pm 10 days and refusal by patient due to transfer to a different hospital. All causes are listed in figure 1.

The primary end point, mean infarct size (\% delayed enhancement of LV) in the metoprolol group was15.29\% 10.97 versus $14.91 \% \pm 11.52$ in the placebo group ( $p=0.616)$. Prereperfusion administration of iv metoprolol did not improve LVEF on MRI $(50.97 \% \pm 10.93 \%$ versus $51.65 \% \pm 10.83 \%$ in the placebo group). These findings are summarized in table 2 .

Table 2 - Magnetic Resonance Imaging (MRI) Data (1 month +/- 10 days after randomization) - LVEDV: left ventricular end diastolic volume, LVESV: left ventricular end systolic volume, LVEF: left ventricular ejection fraction, LV: left ventricle

\begin{tabular}{|c|c|c|c|c|}
\hline Outcome & $\begin{array}{l}\text { Metoprolol } \\
(\mathrm{N}=336)\end{array}$ & $\begin{array}{l}\text { Placebo } \\
(\mathrm{N}=347)\end{array}$ & $\begin{array}{c}\text { Total } \\
(\mathrm{N}=684)\end{array}$ & P-value \\
\hline MRI performed & $169 / 305(55.4 \%)$ & $173 / 319(54.2 \%)$ & $342 / 624(54.8 \%)$ & 0.768 \\
\hline MRI analyzed & $162 / 169(95.9 \%)$ & $169 / 174(97.1 \%)$ & $331 / 343(96.5 \%)$ & 0.523 \\
\hline \multicolumn{4}{|c|}{ Delayed enhancement-Infarct (\% of LV) } & 0.616 \\
\hline Mean \pm SD & $15.3 \pm 11.0$ & $14.1 \pm 11.5$ & $15.1 \pm 11.2$ & \\
\hline Median (IQR) & $13.4(6.4-21.3)$ & $13.3(5.6-21.3)$ & $13.4(5.9-21.3)$ & \\
\hline \multirow[t]{2}{*}{ Min - Max } & $0.00-44.1$ & $0.00-49.9$ & $0.00-49.9$ & \\
\hline & $(n=159)$ & $(n=167)$ & $(n=326)$ & \\
\hline LVEF (\%) & & & & 0.683 \\
\hline Mean \pm SD & $51.0 \pm 10.9$ & $51.7 \pm 10.8$ & $51.2 \pm 10.9$ & \\
\hline Median (IQR) & $53.0(44.1-59.3)$ & $53.3(45.3-58.6)$ & $53.5(44.9-59.3)$ & \\
\hline \multirow[t]{2}{*}{ Min - Max } & $21.0-69.6$ & $15.0-75.8$ & $15.0-75.8$ & \\
\hline & $(n=162)$ & $(n=169)$ & $(n=331)$ & \\
\hline
\end{tabular}


Table 2 - Magnetic Resonance Imaging (MRI) Data (1 month +/- 10 days after randomization) - LVEDV: left ventricular end diastolic volume, LVESV: left ventricular end systolic volume, LVEF: left ventricular ejection fraction, LV: left ventricle (continued)

\begin{tabular}{|c|c|c|c|c|}
\hline Outcome & $\begin{array}{c}\text { Metoprolol } \\
(\mathrm{N}=336)\end{array}$ & $\begin{array}{l}\text { Placebo } \\
(\mathrm{N}=347)\end{array}$ & $\begin{array}{c}\text { Total } \\
(\mathrm{N}=684)\end{array}$ & P-value \\
\hline $\operatorname{LVEDV}(\mathrm{ml})$ & & & & 0.398 \\
\hline Mean \pm SD & $183.9 \pm 52.4$ & $184.2 \pm 40.1$ & $184.0 \pm 46.4$ & \\
\hline Median (IQR) & $177.9(149.1-209.1)$ & $181.8(157.5-212.0)$ & $180.0(153.7-209.9)$ & \\
\hline \multirow[t]{2}{*}{ Min - Max } & $83.6-469.7$ & $85.4-292.8$ & $83.6-469.7$ & \\
\hline & $(n=162)$ & $(n=169)$ & $(n=331)$ & \\
\hline $\operatorname{LVESV}(m \mathrm{l})$ & & & & 0.651 \\
\hline Mean \pm SD & $93.3 \pm 46.1$ & $90.5 \pm 32.91$ & $91.9 \pm 39.9$ & \\
\hline Median (IQR) & $82.7(64.0-108.7)$ & $86.3(65.8-106.1)$ & $85.4(64.8-108.1)$ & \\
\hline \multirow[t]{2}{*}{ Min - Max } & $26.0-359.5$ & $27.8-187.0$ & $26.0-359.5$ & \\
\hline & $(n=162)$ & $(n=169)$ & $(n=331)$ & \\
\hline LV mass $(g)$ from function & & & & 0.893 \\
\hline Mean \pm SD & $96.4 \pm 25.2$ & $96.5 \pm 23.1$ & $96.5 \pm 24.1$ & \\
\hline Median (IQR) & $96.4(77.2-110.7)$ & $94.6(80.6-110.1)$ & $94.8(79.5-110.6)$ & \\
\hline \multirow[t]{2}{*}{ Min - Max } & $48.4-195.4$ & $48.2-187.8$ & $48.2-195.4$ & \\
\hline & $(n=162)$ & $(n=169)$ & $(n=331)$ & \\
\hline \multicolumn{2}{|c|}{ LV mass (g) from delayed enhancement } & & & 0.782 \\
\hline Mean \pm SD & $104.6 \pm 29.0$ & $103.1 \pm 25.7$ & $103.9 \pm 27.5$ & \\
\hline Median (IQR) & $100.6(85.1-122.5)$ & $101.3(84.1-119.0)$ & $100.9(84.3-121.4)$ & \\
\hline \multirow[t]{2}{*}{ Min - Max } & $50.6-244.0$ & $46.7-189.6$ & $46.7-244.0$ & \\
\hline & $(n=159)$ & $(n=167)$ & $(n=326)$ & \\
\hline \multicolumn{2}{|c|}{ Poor quality delayed enhancement images } & & & 0.914 \\
\hline No & $150 / 162(92.6 \%)$ & $157 / 169(92.9 \%)$ & $307 / 331(92.7 \%)$ & \\
\hline Yes & $12 / 162(7.4 \%)$ & $12 / 169(7.1 \%)$ & $24 / 331(7.3 \%)$ & \\
\hline \multicolumn{2}{|l|}{ EDEMA } & & & 0.398 \\
\hline Absence & $10 / 86(11.6 \%)$ & $11 / 102(10.8 \%)$ & $21 / 188(11.2 \%)$ & \\
\hline Small Zone & $17 / 86(19.8 \%)$ & $16 / 102(15.7 \%)$ & $33 / 188(17.6 \%)$ & \\
\hline Extended Zone & $45 / 86(52.3 \%)$ & $48 / 102(47.1 \%)$ & $93 / 188(49.5 \%)$ & \\
\hline Black (hemorrhage) core & $14 / 86(16.3 \%)$ & $27 / 102(26.5 \%)$ & $41 / 188(21.8 \%)$ & \\
\hline \multicolumn{2}{|l|}{ Localization } & & & 0.742 \\
\hline No evidence of infarction & $12 / 162(7.4 \%)$ & $8 / 170(4.7 \%)$ & $20 / 332(6.0 \%)$ & \\
\hline Anterior or septal & $71 / 162(43.8 \%)$ & $75 / 170(44.1 \%)$ & $146 / 332(44.0 \%)$ & \\
\hline Inferior & $47 / 162(29.0 \%)$ & $57 / 170(33.5 \%)$ & $104 / 332(31.3 \%)$ & \\
\hline Lateral or inferolateral & $24 / 162(14.8 \%)$ & $24 / 170(14.1 \%)$ & $48 / 332(14.5 \%)$ & \\
\hline Typical of myocarditis & $8 / 162(4.9 \%)$ & $6 / 170(3.5 \%)$ & $14 / 332(4.2 \%)$ & \\
\hline
\end{tabular}




\section{Secondary Endpoints}

The peak creatinine kinase (CK), peak CK-MB and troponin levels at 24 hours were available in 591 (86.4\%) patients. Peak CK was $2102 \pm 2029 \mathrm{U} / \mathrm{L}$ in the metoprolol group vs $2072 \pm$ $2018 \mathrm{U} / \mathrm{L}$ in the placebo group. $p=0.88$. Mean single Troponin T measured at 24 hours of hospitalization period was $3711 \pm 3587 \mathrm{ng} / \mathrm{L}$ in the metoprolol group versus $3166 \pm 3998$ $\mathrm{ng} / \mathrm{L}$ in the placebo group $(\mathrm{p}=0.1)$. Results of enzymatic infarct size are summarized in figure 2 and 3 (area under the curve).

Major adverse cardiac events (MACE) at 30 days occurred in 19 patients $(6.2 \%)$ in the metoprolol group and 22 patients $(6.9 \%)$ in the placebo group ( $P=0.72)$.

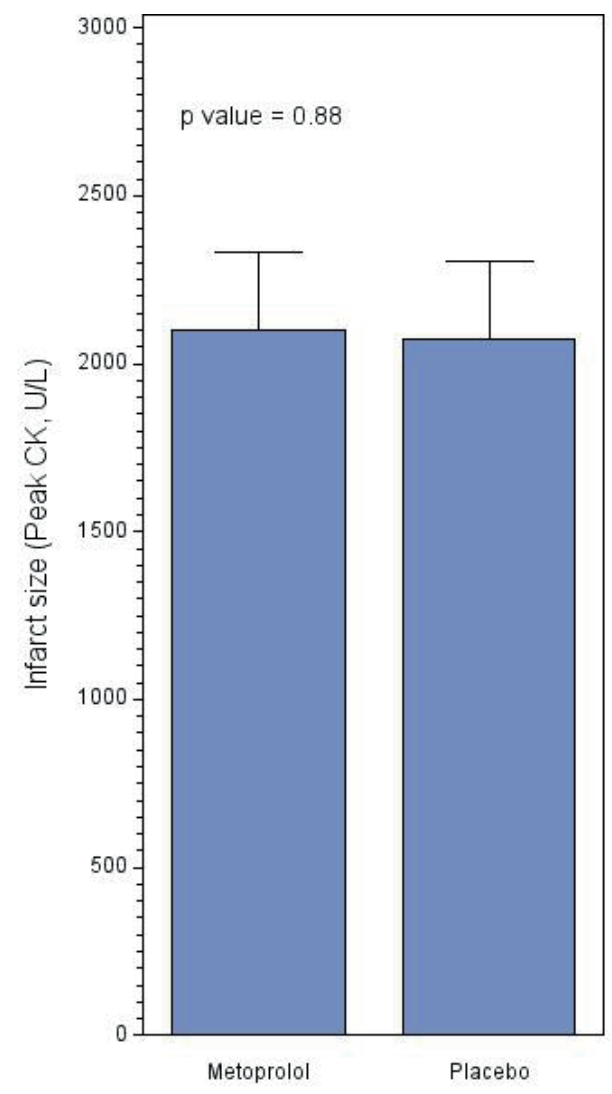

Figure 2 - Enzymatic infarct size estimated by peak creatine kinase (CK)

\section{Safety Endpoints}

Pre-Reperfusion administration of iv metoprolol did not change the incidence of the prespecified secondary safety endpoints. There were 16 (4.8\%) safety events in the metoprolol group and $11(3.2 \%)$ events in the placebo group, $p=0.271$. Safety endpoints and adverse 


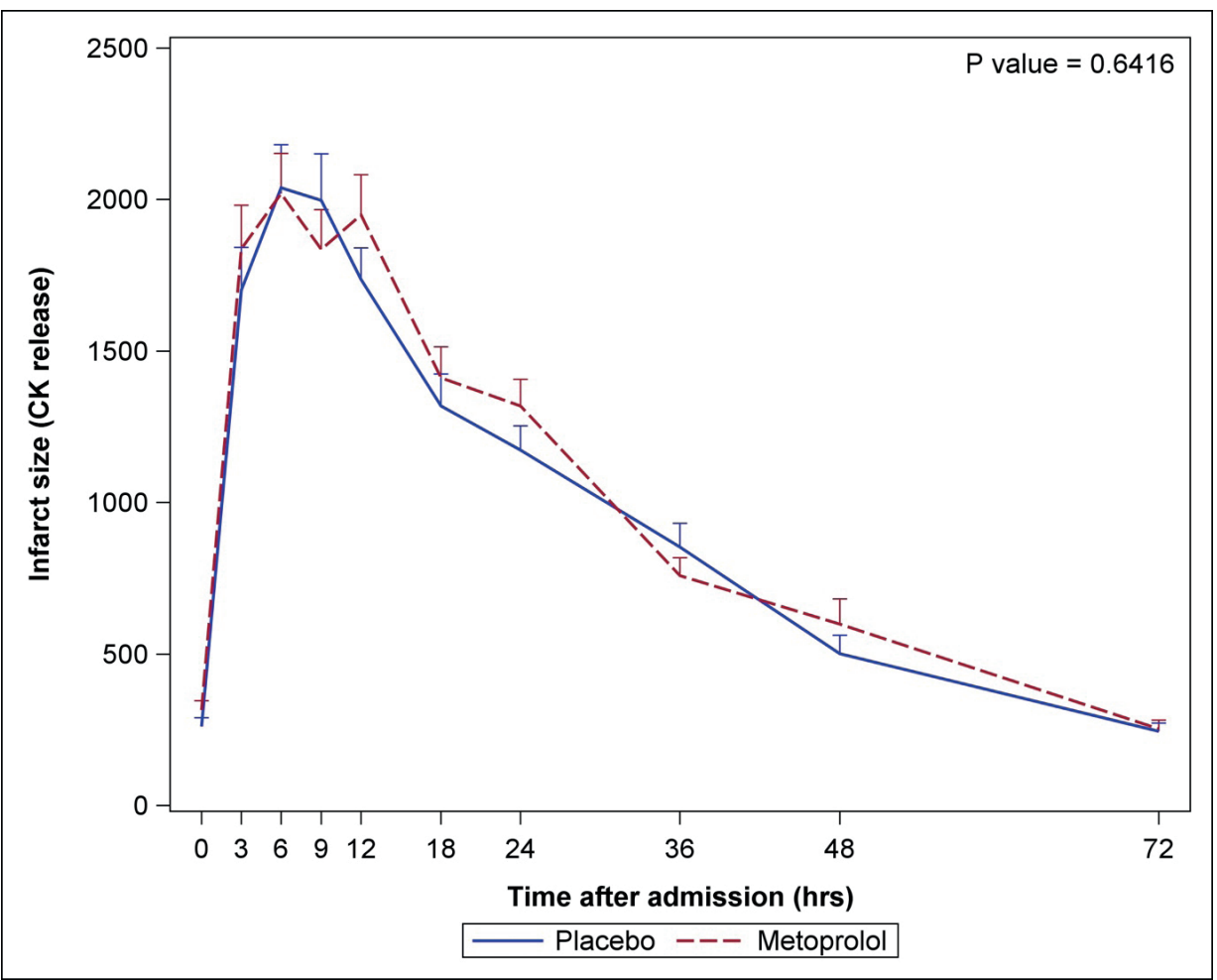

Figure 3 - Enzymatic infarct size estimated by area under the creatine kinase (CK) curve.

cardiac events are presented in table 3. Bradycardia was observed in $4.2 \%$ in the metoprolol group, compared to $2.6 \%$ in the placebo group $(p=0.25)$. There was however a borderline significant reduction in the occurrence of malignant arrhythmias in the acute phase in the metoprolol group, 12 patients (3.6\%) vs 24 patients $(6.9 \%, \mathrm{P}=0.050)$.

Table 3 - Safety endpoints

\begin{tabular}{lcccc}
\hline Outcome & $\begin{array}{c}\text { Metoprolol } \\
(\mathbf{N}=336)\end{array}$ & $\begin{array}{c}\text { Placebo } \\
(\mathbf{N}=347)\end{array}$ & $\begin{array}{c}\text { Total } \\
(\mathbf{N}=684)\end{array}$ & P-value \\
\hline Severe bradycardia & $5 / 334(1.5 \%)$ & $2 / 345(0.6 \%)$ & $7 / 679(1.0 \%)$ & 0.279 \\
Servere hypotension & $9 / 310(2.9 \%)$ & $18 / 326(5.5 \%)$ & $27 / 636(4.2 \%)$ & 0.102 \\
Cardiogenic shock & $2 / 334(0.6 \%)$ & $1 / 345(0.3 \%)$ & $3 / 679(0.4 \%)$ & 0.618 \\
Ventricular arrhythmias in acute phase & $12 / 335(3.6 \%)$ & $24 / 346(6.9 \%)$ & $36 / 681(5.3 \%)$ & 0.050 \\
\hline
\end{tabular}

\section{Prespecified subgroup analysis}

Infarct size 1 month after STEMI did not differ in patients presenting with an anterior infarction between the metoprolol group $(18.8 \pm 12.2 \%)$ and the placebo group (19.3 \pm 
12.7\%. $p=0.33$ ). The infarct size in patients with a non-anterior infarction was $12.2 \pm 8.0 \%$ in the metoprolol group and $10.4 \pm 7.8$ in the placebo group. Patients presenting $<6$ hours after symptom onset also did not benefit from pre-reperfusion metoprolol administration compared to patients presenting $>6$ hours after symptom onset. Infarct size in patients with an occluded vessel (TIMI 0 and 1 flow) at the time of coronary angiography did not differ between the metoprolol and placebo group ( $17.8 \pm 10.8$ versus $18.1 \pm 11.8 \%, p=0.74)$. Data from these prespecified subgroups are shown in figure 4.

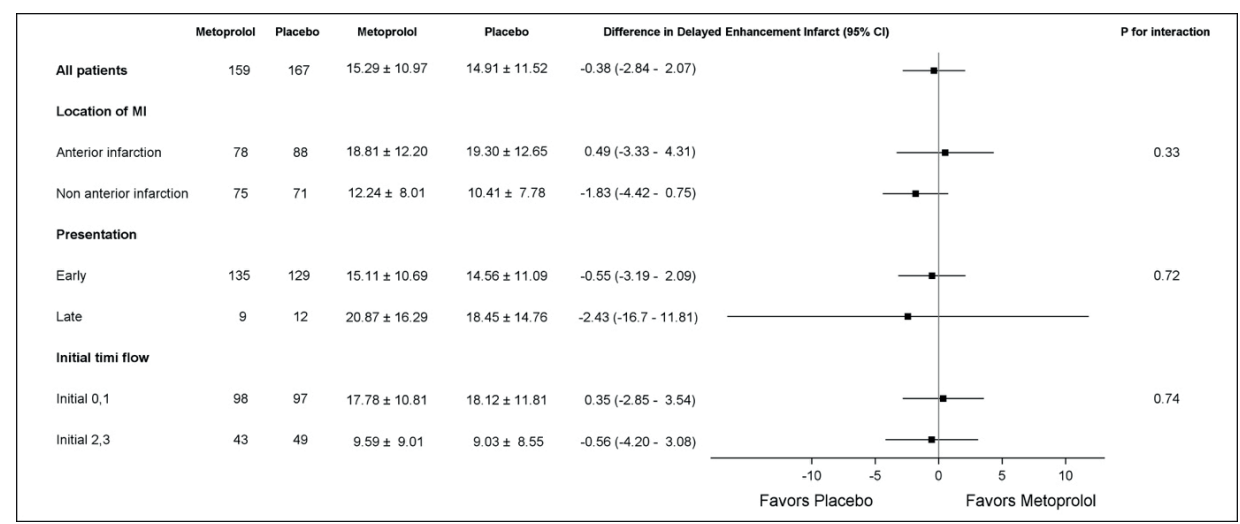

Figure 4 - Prespecified subgroup analysis

Table 4 - Adverse cardiac events at 30 days

\begin{tabular}{lcccc}
\hline Outcome & $\begin{array}{c}\text { Metoprolol } \\
\mathbf{( N = 3 3 6 )}\end{array}$ & $\begin{array}{c}\text { Placebo } \\
(\mathbf{N}=347)\end{array}$ & $\begin{array}{c}\text { Total } \\
(\mathbf{N}=684)\end{array}$ & \begin{tabular}{c} 
P-value \\
\hline MACE
\end{tabular} \\
Cardiac mortality & $19 / 307(6.2 \%)$ & $22 / 319(6.9 \%)$ & $41 / 626(6.5 \%)$ & 0.721 \\
MI & $7 / 307(2.3 \%)$ & $7 / 319(2.2 \%)$ & $14 / 626(2.2 \%)$ & 0.942 \\
TVR & $3 / 307(1.0 \%)$ & $2 / 319(0.6 \%)$ & $5 / 626(0.8 \%)$ & 0.681 \\
\hline
\end{tabular}

\section{DISCUSSION}

In this double-blind, randomized controlled trial, in patients with STEMI undergoing primary $\mathrm{PCl}$, pre-reperfusion administration of up to $10 \mathrm{mg}$ metoprolol i.v. was safe, but had no effect on infarct size or LVEF.

$\beta$-Blockers have multiple actions on the heart. Blockade of $\beta 1$ receptors results in slowing of heart rate, reduction in myocardial contractility, and lowering of systemic blood pressure. In the context of acute myocardial infarction, which represents a state of reduced oxygen supply to the affected portion of the heart, these effects may be beneficial, as they result in 
Table 5 - Secondary endpoints

\begin{tabular}{|c|c|c|c|c|}
\hline Outcome & $\begin{array}{l}\text { Metoprolol } \\
(\mathrm{N}=336)\end{array}$ & $\begin{array}{l}\text { Placebo } \\
(\mathrm{N}=347)\end{array}$ & $\begin{array}{c}\text { Total } \\
(\mathrm{N}=684)\end{array}$ & P-value \\
\hline Maximal CKMB ull value & & & & 0.750 \\
\hline Mean \pm SD & $224 \pm 212$ & $213 \pm 195$ & $218 \pm 203$ & \\
\hline Median (IQR) & $148(65-327)$ & $167(57-300)$ & $155(62-317)$ & \\
\hline \multirow[t]{2}{*}{ Min - Max } & $9-998$ & $10-943$ & $9-998$ & \\
\hline & $(n=207)$ & $(n=204)$ & $(n=411)$ & \\
\hline Maximal CKMB ug/l value & & & & 0.181 \\
\hline Mean \pm SD & $276 \pm 243$ & $232 \pm 254$ & $254 \pm 248$ & \\
\hline Median (IQR) & $188(97-450)$ & $133(49-282)$ & $152(60-440)$ & \\
\hline \multirow[t]{2}{*}{ Min - Max } & $3-880$ & $0-969$ & $0-969$ & \\
\hline & $(n=52)$ & $(n=54)$ & $(n=106)$ & \\
\hline Maximal CK-total & & & & 0.880 \\
\hline Mean \pm SD & $2102 \pm 2029$ & $2072 \pm 2018$ & $2087 \pm 2022$ & \\
\hline Median (IQR) & $1370(538-3050)$ & 1411 (466- 2980) & $1376(504-3050)$ & \\
\hline \multirow[t]{2}{*}{ Min - Max } & $47-9857$ & $30-8769$ & $30-9857$ & \\
\hline & $(n=298)$ & $(n=293)$ & $(n=591)$ & \\
\hline hs Trop T (ng/L) 24 hours & & & & 0.103 \\
\hline Mean \pm SD & $3711 \pm 3587$ & $3166 \pm 3998$ & $3451 \pm 3790$ & \\
\hline Median (IQR) & $2530(1200-5450)$ & 1994 (962.5- 3800) & $2224(1059-4800)$ & \\
\hline \multirow[t]{2}{*}{ Min - Max } & $22.40-19480$ & $1.25-31700$ & $1.25-31700$ & \\
\hline & $(n=114)$ & $(n=104)$ & $(n=218)$ & \\
\hline Trop I (ug/L) 24 hours & & & & 0.948 \\
\hline Mean \pm SD & $42.37 \pm 39.85$ & $53.04 \pm 56.49$ & $48.26 \pm 49.19$ & \\
\hline Median (IQR) & $32.60(13.30-58.99)$ & $32.83(9.28-74.71)$ & $32.60(9.70-58.99)$ & \\
\hline \multirow[t]{2}{*}{ Min - Max } & $0.65-136.5$ & $0.07-177.1$ & $0.07-177.1$ & \\
\hline & $(n=13)$ & $(n=16)$ & $(n=29)$ & \\
\hline
\end{tabular}

reduced myocardial workload and oxygen demand. Furthermore, $\beta$-blockers decrease the incidence of life-threatening arrhythmias, reinfarction, and recurrent ischemia, preventing LV remodeling. $(11,13-15,18-21)$ They have demonstrated to be beneficial, resulting in a mortality reduction in patients with reduced LV function and when administered after MI. However, there is debate whether pre-reperfusion administration of intravenous $\beta$-blockers may reduce reperfusion injury as compared with post reperfusion administration. (22) The MIAMI trial tested the effect of pre-reperfusion metoprolol ( $3 \times 5 \mathrm{mg}$ intravenous) versus placebo in STEMI $(n=5778)$ treated by thrombolysis and demonstrated no effect of metoprolol. (11) In the COMMIT CC2 trial ( $n=45,825)$, intravenous metoprolol $3 \times 5 \mathrm{mg}$ intravenous followed by oral administration up to 4 weeks did not improve survival in STEMI patients. (12) However, this was mainly caused by a higher incidence of cardiogenic shock in patients 
treated by early $\beta$-blocker, possibly due to inclusion of patients with heart failure. In the current era of primary $\mathrm{PCI}$, the METOCARD-CNIC trial showed reduced infarct size and increased LV ejection fraction in STEMI patients without signs of heart failure treated with early intravenous metoprolol. $(14,23)$ However, this study had a relatively small sample size $(\mathrm{N}=270)$, was not blinded, not placebo controlled, and included a selected patient group (anterior STEMI presenting $<6$ hours from symptom onset). Our study included all patients with STEMI, with a double-blinded, placebo-controlled design. Our results do not confirm the effect observed in the METOCARD-CNIC trial. One possible explanation could be that the METOCARD-CNIC trial included only anterior infarctions, the average infarct size (infarcted myocardium, \% LV) in the METOCARD-CNIC trial was $21.2 \%$ in patients treated with iv metoprolol, compared to $15.3 \%$ in our study. These differences could support this theory. The smaller the infarctions, the less likely an additional treatment effect can be demonstrated. However, also the subgroup with anterior infarction had no benefit of early beta blocker treatment. In METOCARD-CNIC, the dose of metoprolol was higher, up to 3 times $5 \mathrm{mg}$ (15 mg target dose), whereas in our trial only two times $5 \mathrm{mg}$ (10 mg target dose) was given. Another explanation can be that $18.8 \%$ of patients in our trial were on long term beta-blocker treatment before admission, however this was an exclusion criteria in the METOCARD trial. Also, the timing of the MRI can be of influence. In the METOCARD trial 2 MRI's were performed: One at 5-7 days, and the second at 6 months. Data from the first MRI at 5-7 days showed an improvement in LVEF in the metoprolol group and a significant reduction in infarct size. The follow-up MRI data at 6 months showed an even more significant difference in LVEF favoring the metoprolol group, but with no significant difference in infarct size any more. Comparing the MRI infarct size as \% of LV in the metoprolol group, it was $15.7 \% \pm 9.6$ in the METOCARD-CNIC trial at 6 months; vs $15.3 \% \pm 11.0$ in our trial at one month. Another potential reason responsible for the different effect observed in this trial compared to the METOCARD-CNIC trial is the timing of metoprolol administration: A recent subanalysis of the METOCARD-CNIC trial (24), showed that the timing of metoprolol administration is a critical factor accounting for its infarct-limiting effect. That subanalysis, showed that only patients receiving i.v. metoprolol long before reperfusion had a reduction in infarct size. METOCARDCNIC trial patients receiving i.v. metoprolol close to $\mathrm{pPCI}$ had significantly larger infarctions than those receiving i.v. metoprolol long before reperfusion, and similar to control patients. In the present Early-BAMI trial, the second $5 \mathrm{mg}$ bolus (to complete the 10mg target dose) was administered per protocol immediately before catheterization (median time from bolus and reperfusion $14 \mathrm{~min}$ ). The first $5 \mathrm{mg}$ of iv metoprolol might be insufficient to attain cardio protection, in fact blood pressure after the first bolus of medication (i.e. before second bolus) was not different between metoprolol and placebo arms in this trial, supporting the lowdosing hypothesis. Based on these data, and the conflicting results with METOCARD-CNIC, additional randomized trials are needed to clarify whether early beta-blocker treatment has any effect in these patients. We advocate that future studies should test the cardioprotective 
effects of i.v. metoprolol in STEMI patients and should have a target dose of $15 \mathrm{mg}$ and administer medication immediately after STEMI diagnosis to allow a maximum "on-board" metoprolol time before reperfusion. The safety profile, low cost, and the reduction of acute malignant arrhythmias seen in this trial encourage the performance of additional larger trials in this regard. In most randomized trials in which infarct size or LVEF was measured with MRI, MRI was performed at one month. $(25,26)$ This was the main reason why we choose one month in our trial. All participating $\mathrm{PCl}$ centers and ambulance services had a long-standing experience in prehospital triage and treatment of STEMI patients. Regional differences in systems of care in which prehospital drug administration in the ambulance differ (Europe vs US), can lead to different interpretation of these study results to daily practice.

\section{LIMITATIONS}

During the course of the trial, the primary endpoint was changed from enzymatic infarct size to infarct size measured by MRI. The change in the primary outcome was made in order to reduce the necessary sample size and infarct size could be studied more precisely with MRI. The results from enzymatic infarct size analysis however were completely in line with the results from the primary MRI end point.

The trial was powered with a reduction of infarct size from $28 \%$ to $23.5 \%$. The smaller than estimated infarct size in this trial $(15.1 \%$ ) could affect the neutral effect of the trial, (the smaller the infarct size, the less probability that a difference could be found). However, also in the larger anterior infarctions there was no observed effect. Also, patients who died before MRI was performed, with probably larger infarctions, may have caused a selection of patients with smaller infarctions who had MRI.

Although we defined several sub analyses, these analyses should be interpreted with caution, since the included patients in several subgroups were small. It was not possible to blind physicians and nurses for heart rate and blood pressure. However, analyses of MRI (primary end point) were blinded for both heart rate and study medication.

\section{CONCLUSION}

Early pre-reperfusion administration of intravenous metoprolol, at a dose of $10 \mathrm{mg}(2 \times 5$ $\mathrm{mg}$ ) had no beneficial effects on infarct size in patients with STEMI treated by primary PCI. 


\section{ACKNOWLEDGMENT}

We are grateful for the commitment of all the ambulance personnel in the Netherlands (RAV IJsselland, Witte kruis, RAV UMCG) and in Spain at SUMMA 112. The recruitment of patients in Spain was performed within the "Codigo Infarto" Network. BI, GP, NE and FF-A are members of the Red de Investigación Cardiovascular-RIC (RETIC\# RD12/0042/0054, RETIC\#RD12/0042).

All co-investigators in the different hospitals have been capital for the rigorous conduct of this trial.

The Early-BAMI trial was an investigator initiated, non-commercial trial. The trial was funded by a research grant from the Dutch Heart Foundation (Utrecht, Netherlands) (no. 2010B125) and an unrestricted grant of Medtronic Inc. (Heerlen, The Netherlands). QMass software version MR 7.6 was partially supported by a scientific collaboration between CNIC and Medis.

\section{Disclosures}

None. 


\section{Appendix}

\begin{tabular}{|c|c|c|c|c|}
\hline Characteristics & $\begin{array}{c}\text { MRI } \\
(\mathrm{N}=342)\end{array}$ & $\begin{array}{l}\text { No MRI } \\
(\mathrm{N}=341)\end{array}$ & $\begin{array}{c}\text { Total } \\
(\mathrm{N}=683)\end{array}$ & P-value \\
\hline Age (years) & & & & 0.003 \\
\hline Mean \pm SD & $60.93 \pm 12.02$ & $63.92 \pm 12.80$ & $62.42 \pm 12.49$ & \\
\hline Median (IQR) & $61.17(52.72-68.52)$ & $62.71(54.80-73.51)$ & $61.79(53.72-71.08)$ & \\
\hline \multirow[t]{2}{*}{ Min - Max } & $25.80-92.83$ & $29.21-93.29$ & $25.80-93.29$ & \\
\hline & $(n=342)$ & $(n=340)$ & $(n=682)$ & \\
\hline Gender & & & & 0.013 \\
\hline Female & $72 / 342(21.1 \%)$ & $100 / 341(29.3 \%)$ & $172 / 683(25.2 \%)$ & \\
\hline Male & $270 / 342(78.9 \%)$ & $241 / 341(70.7 \%)$ & $511 / 683(74.8 \%)$ & \\
\hline Length & & & & 0.111 \\
\hline Mean \pm SD & $174.2 \pm 9.95$ & $175.6 \pm 9.81$ & $174.8 \pm 9.91$ & \\
\hline Median (IQR) & $175.0(168.0-181.0)$ & $176.0(170.0-184.0)$ & $175.0(168.0-182.0)$ & \\
\hline \multirow[t]{2}{*}{ Min - Max } & $144.00-198.00$ & $150.00-196.00$ & $144.00-198.00$ & \\
\hline & $(n=321)$ & $(n=252)$ & $(n=573)$ & \\
\hline Weight & & & & 0.434 \\
\hline Mean \pm SD & $83.06 \pm 15.99$ & $84.64 \pm 16.49$ & $83.78 \pm 16.23$ & \\
\hline Median (IQR) & $83.00(72.00-93.00)$ & $84.50(73.00-95.00)$ & $83.00(72.00-94.00)$ & \\
\hline \multirow[t]{2}{*}{ Min - Max } & $43.00-135.00$ & $52.00-170.00$ & $43.00-170.00$ & \\
\hline & $(n=329)$ & $(n=274)$ & $(n=603)$ & \\
\hline$B M I$ & & & & 0.413 \\
\hline Mean \pm SD & $27.28 \pm 4.06$ & $27.26 \pm 4.56$ & $27.27 \pm 4.28$ & \\
\hline Median (IQR) & $26.88(24.76-29.45)$ & $26.52(24.41-29.22)$ & $26.73(24.54-29.32)$ & \\
\hline \multirow[t]{2}{*}{ Min - Max } & $17.67-42.61$ & $18.41-52.47$ & $17.67-52.47$ & \\
\hline & $(n=320)$ & $(n=250)$ & $(n=570)$ & \\
\hline First contact & & & & $<.001$ \\
\hline Referring hospital & $25 / 342(7.3 \%)$ & $10 / 340(2.9 \%)$ & $35 / 682(5.1 \%)$ & \\
\hline $\mathrm{PCl}$ center & $16 / 342(4.7 \%)$ & $4 / 340(1.2 \%)$ & $20 / 682(2.9 \%)$ & \\
\hline Ambulance & $301 / 342(88.0 \%)$ & $326 / 340(95.9 \%)$ & $627 / 682(91.9 \%)$ & \\
\hline \multicolumn{4}{|c|}{$\begin{array}{l}\text { Time (minutes) between onset date and time and first contact date and } \\
\text { time }\end{array}$} & 0.564 \\
\hline Mean \pm SD & $150.5 \pm 270.8$ & $133.4 \pm 164.1$ & $141.7 \pm 222.3$ & \\
\hline Median (IQR) & $75.00(41.00-160.0)$ & $77.00(34.00-150.0)$ & $76.00(36.00-159.0)$ & \\
\hline \multirow[t]{2}{*}{ Min - Max } & $0.00-3090.0$ & $5.00-1200.0$ & $0.00-3090.0$ & \\
\hline & $(n=299)$ & $(n=318)$ & $(n=617)$ & \\
\hline \multicolumn{3}{|c|}{ Early presenters (within 6 hours) } & & 0.954 \\
\hline Yes & $274 / 299(91.6 \%)$ & 291/318 (91.5\%) & $565 / 617(91.6 \%)$ & \\
\hline \multicolumn{4}{|c|}{ Time (minutes) between onset date and time and admission date and time } & 0.851 \\
\hline Mean \pm SD & $206.2 \pm 311.8$ & $186.7 \pm 186.2$ & $196.3 \pm 255.9$ & \\
\hline Median (IQR) & $123.5(81.00-220.5)$ & $120.0(85.00-200.0)$ & $120.0(83.00-211.0)$ & \\
\hline
\end{tabular}




\begin{tabular}{|c|c|c|c|c|}
\hline Characteristics & $\begin{array}{c}\text { MRI } \\
(\mathrm{N}=342)\end{array}$ & $\begin{array}{l}\text { No MRI } \\
(\mathrm{N}=341)\end{array}$ & $\begin{array}{c}\text { Total } \\
(\mathrm{N}=683)\end{array}$ & P-value \\
\hline \multirow[t]{2}{*}{ Min - Max } & $30.00-3187.0$ & $20.00-1675.0$ & $20.00-3187.0$ & \\
\hline & $(n=308)$ & $(n=317)$ & $(n=625)$ & \\
\hline CKmax & & & & 0.009 \\
\hline Mean \pm SD & $2239 \pm 2059$ & $1936 \pm 1976$ & $2087 \pm 2022$ & \\
\hline Median (IQR) & $1590(704.0-3220)$ & $1184(385.5-2924)$ & $1370(504.0-3050)$ & \\
\hline \multirow[t]{2}{*}{ Min - Max } & $47.00-9857$ & $30.00-9540$ & $30.00-9857$ & \\
\hline & $(n=294)$ & $(n=296)$ & $(n=590)$ & \\
\hline
\end{tabular}




\section{REFERENCES}

1. Fokkema ML, James SK, Albertsson P et al. Population trends in percutaneous coronary intervention: 20-year results from the SCAAR (Swedish Coronary Angiography and Angioplasty Registry). J Am Coll Cardiol 2013;61:1222-30.

2. Van de Werf F, Bax J, Betriu A et al. Management of acute myocardial infarction in patients presenting with persistent ST-segment elevation: the Task Force on the Management of STSegment Elevation Acute Myocardial Infarction of the European Society of Cardiology. Eur Heart J 2008;29:2909-45.

3. Dargie HJ. Effect of carvedilol on outcome after myocardial infarction in patients with leftventricular dysfunction: the CAPRICORN randomised trial. Lancet 2001;357:1385-90.

4. Feuerstein GZ, Yue TL, Cheng HY, Ruffolo RR, Jr. Myocardial protection by the novel vasodilating beta-blocker, carvedilol: potential relevance of anti-oxidant activity. J Hypertens Suppl 1993;11:S41-8.

5. Hammerman H, Kloner RA, Briggs LL, Braunwald E. Enhancement of salvage of reperfused myocardium by early beta-adrenergic blockade (timolol). J Am Coll Cardiol 1984;3:1438-43.

6. Rasmussen MM, Reimer KA, Kloner RA, Jennings RB. Infarct size reduction by propranolol before and after coronary ligation in dogs. Circulation 1977;56:794-8.

7. Reduction of infarct size with the early use of timolol in acute myocardial infarction. The New Engl J Med 1984;310:9-15.

8. Peter T, Heng MK, Singh BN et al. Failure of high doses of propranolol to reduce experimental myocardial ischemic damage. Circulation 1978;57:534-40.

9. Rude RE, Buja LM, Willerson JT. Propranolol in acute myocardial infarction: the MILIS experience. Am J Cardiol 1986; 57:38F-42F.

10. Yusuf S, Sleight $P$, Rossi $P$ et al. Reduction in infarct size, arrhythmias and chest pain by early intravenous beta blockade in suspected acute myocardial infarction. Circulation 1983;67:132-41.

11. Metoprolol in acute myocardial infarction (MIAMI). A randomised placebo-controlled international trial. The MIAMI Trial Research Group. Eur Heart J 1985;6:199-226.

12. Herlitz J, Waagstein F, Lindqvist J, Swedberg K, Hjalmarson A. Effect of metoprolol on the prognosis for patients with suspected acute myocardial infarction and indirect signs of congestive heart failure (a subgroup analysis of the Goteborg Metoprolol Trial). Am J Cardiol 1997;80:40J44J.

13. Hanada K, Higuma T, Nishizaki F et al. Randomized study on the efficacy and safety of landiolol, an ultra-short-acting beta1-adrenergic blocker, in patients with acute myocardial infarction undergoing primary percutaneous coronary intervention. Circ J;76:439-45.

14. Ibanez B, Macaya C, Sanchez-Brunete $V$ et al. Effect of Early Metoprolol on Infarct Size in STSegment Elevation Myocardial Infarction Patients Undergoing Primary PCI: The METOCARD-CNIC Trial. Circulation 2013.

15. Ibanez B, Fuster V, Macaya C et al. Study design for the "effect of METOprolol in CARDioproteCtioN during an acute myocardial InfarCtion" (METOCARD-CNIC): a randomized, controlled parallel-group, observer-blinded clinical trial of early pre-reperfusion metoprolol administration in ST-segment elevation myocardial infarction. Am Heart J;164:473-480 e5.

16. Roolvink V, Van't Hof AW, van der Horst IC. The sooner, the better: early beta-blocker administration in patients with ST-elevation myocardial infarction. Critical care Med;2013;41:1566-8.

17. Roolvink $V$, Rasoul S, Ottervanger JP et al. Rationale and design of a double-blind, multicenter, randomized, placebo-controlled clinical trial of early administration of intravenous beta-blockers 
in patients with ST-elevation myocardial infarction before primary percutaneous coronary intervention: EARLY beta-blocker administration before primary PCI in patients with ST-elevation myocardial infarction trial. Am Heart J 2014;168:661-6.

18. Wu E, Ortiz JT, Tejedor $P$ et al. Infarct size by contrast enhanced cardiac magnetic resonance is a stronger predictor of outcomes than left ventricular ejection fraction or end-systolic volume index: prospective cohort study. Heart 2008;94:730-6.

19. Atar D, Petzelbauer P, Schwitter J et al. Effect of intravenous FXO6 as an adjunct to primary percutaneous coronary intervention for acute ST-segment elevation myocardial infarction results of the F.I.R.E. (Efficacy of FXO6 in the Prevention of Myocardial Reperfusion Injury) trial. J Am Coll Cardiol 2009;53:720-9.

20. Hirsch/ MM, Wollmann CG, Erhart F et al. Benefit of immediate beta-blocker therapy on mortality in patients with ST-segment elevation myocardial infarction. Critical care Med;2013;41:1396404.

21. Randomised trial of intravenous atenolol among 16027 cases of suspected acute myocardial infarction: ISIS-1. First International Study of Infarct Survival Collaborative Group. Lancet 1986;2:57-66.

22. Ibanez B, Heusch $G$, Ovize M, Van de Werf F. Evolving therapies for myocardial ischemia/reperfusion injury. J Am Coll Cardiol 2015;65:1454-71.

23. Pizarro G, Fernandez-Friera L, Fuster $V$ et al. Long term benefit of early pre-reperfusion metoproIol administration in patients with acute myocardial infarction: results from the METOCARD-CNIC trial. J Am Coll Cardiol 2014;63:2356-62.

24. 24 García-Ruiz JM, Fernández-Jiménez R, García-Alvarez $A$ et al. Impact of the timing of metoprolol administration during ongoing STEMI on infarct size and ventricular function: a METOCARD-CNIC trial substudy with an experimental validation. J Am Coll Cardiol 2016 In Press

25. Eppinga RN, Hartman MH, van Veldhuisen DJ et al. Effect of Metformin Treatment on Lipoprotein Subfractions in Non-Diabetic Patients with Acute Myocardial Infarction: A Glycometabolic Intervention as Adjunct to Primary Coronary Intervention in ST Elevation Myocardial Infarction (GIPS-III) Trial. PloS one 2016;11:e0145719.

26. Belonje $A M$, Voors $A A$, van Gilst WH et al. Effects of erythropoietin after an acute myocardial infarction: rationale and study design of a prospective, randomized, clinical trial (HEBE III). Am Heart J 2008; 155:817-22. 



\section{One-year clinical outcome of early administration of intravenous beta- blockers in patients with ST-segment elevation myocardial infarction before primary percutaneous coronary intervention. One-year results from the EARLY-BAMI trial.}

Vincent Roolvink, Jan Paul Ottervanger, Borja Ibáñez, Jan Henk Dambrink, Marcel Gosselink, Elvin Kedhi, Niels van Royen, Erik Lipsic, Wouter Remkes, Jan Piek, Valentin Fuster, Arnoud van 't Hof. 


\section{ABSTRACT}

The EARLY-BAMI (Early intravenous beta-blockers in patients with ST-segment elevation myocardial infarction before PPCI) trial included 684 STEMI patients to iv metoprolol or matched placebo before PPCl. One-year clinical outcome was defined by major cardiac adverse event (MACE) rate, defined as cardiac death, nonfatal reinfarction, or target vessel revascularization.

\section{Results}

One year follow up was obtained in 629 patients (92\%). Mean follow- up time was 374 +/20 days in the metoprolol group vs $373+/-23$ days in the placebo group. Incidence of MACE at one year was $7.7 \%$ in the metoprolol group vs $7.3 \%$ in the placebo group. $P=0.835$.

\section{Conclusions}

In a nonrestricted STEMI population undergoing PPCl, early pre-hospital iv metoprolol before reperfusion did not result into a reduction in clinical events at one year. 


\section{INTRODUCTION}

The potential of $\beta$-blockers to limit myocardial necrosis was proposed long ago, but their cardio protective capacity during STEMI has been disputed.

The Early-BAMI (Early intravenous Beta-blockers in patients with ST-segment elevation Myocardial Infarction before primary percutaneous coronary intervention) trial showed no reduction on infarct size in patients treated with iv metoprolol before PPCI. (1) In this paper, we report the one-year clinical outcome of the Early BAMI trial. (EudraCT no: 2010-023394-19)

\section{METHODS}

The study design has been published previously. (2) The Early-BAMI trial was a doubleblinded, placebo controlled randomized clinical trial.

Patients $>18$ years of age with symptoms of acute STEMI for $>30$ minutes but $<12$ hours, plus ST-segment elevation $>1 \mathrm{mV}$ in 2 adjacent electrocardiogram (ECG) leads or new left bundle branch block (LBBB) were eligible for enrollment. Exclusion criteria were Killip class III and IV, systolic blood pressure (BP) $<100 \mathrm{mmHg}$, heartrate $<60$ beats/min, type II and III atrioventricular block.

The protocol included one-year follow-up for all patients regarding major adverse cardiac event (MACE) rate, defined as the pre-specified composite of cardiac death, nonfatal myocardial infarction, and revascularization.

\section{RESULTS}

Between February 2012 and November 2015, a total of 683 patients were randomized to metoprolol $(n=336)$ or placebo $(n=346)$. Mean age was $62+/-12$ years and $75 \%$ was male. The median time from first study dose to reperfusion was 54 min (32-72min). One year follow up was obtained in 629 patients (92\%). Kaplan- Meier curves concerning MACE (composite endpoint of cardiac death, nonfatal re-infarction or target vessel revascularization) are shown in Figure 1 and demonstrate no differences between the treatment groups. The rate of MACE and other endpoints (hospitalization for heart failure and indication for an internal cardiac defibrillator (ICD)) are listed in table 1. 


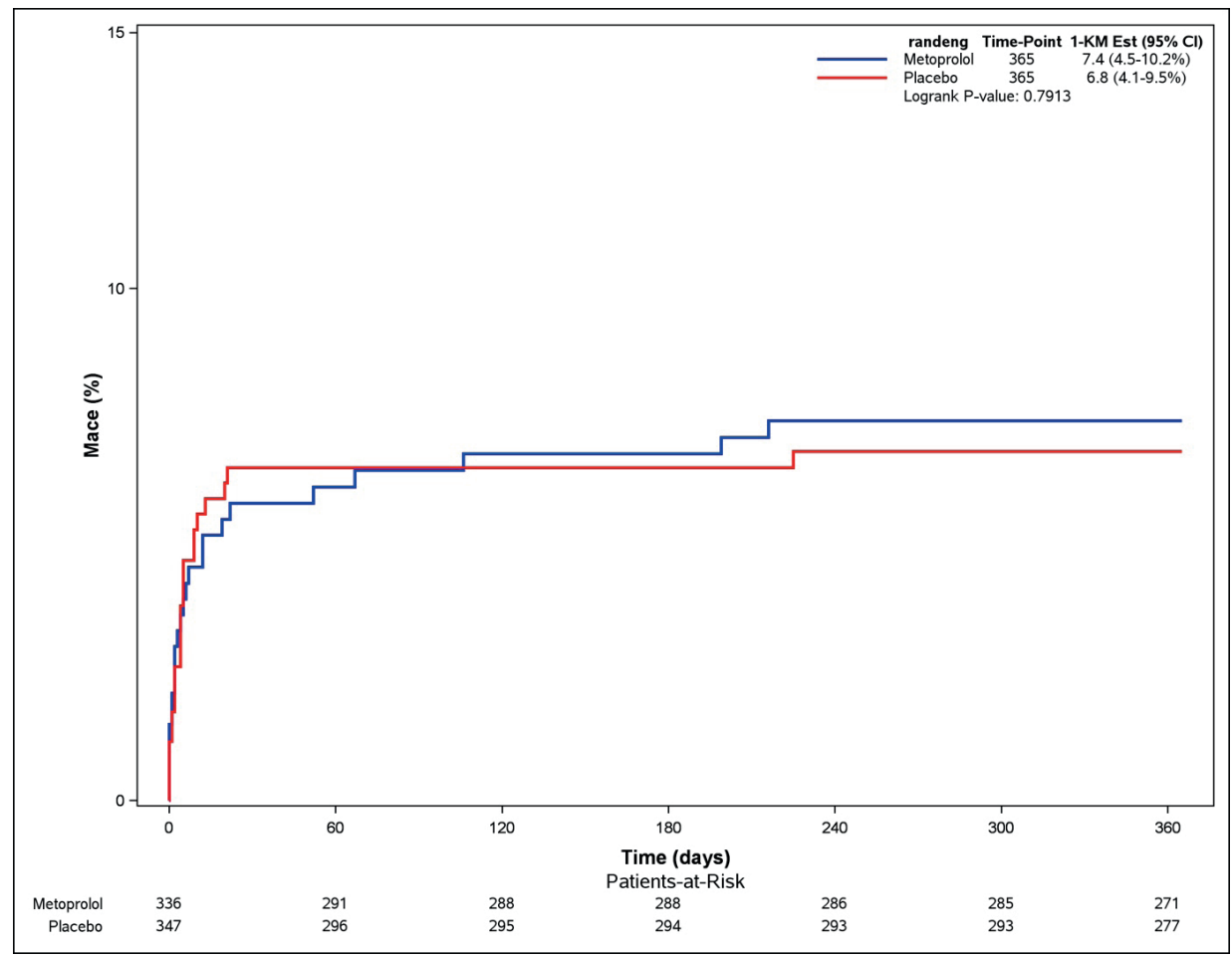

Figure 1 - Kaplan Meier curve for MACE by treatment group

Table 1 - One year clinical endpoints by treatment group

\begin{tabular}{lccccc}
\hline & $\begin{array}{c}\text { Metoprolol } \\
(\mathrm{N}=336)\end{array}$ & $\begin{array}{c}\text { Placebo } \\
(\mathrm{N}=347)\end{array}$ & $\begin{array}{c}\text { Total } \\
(\mathrm{N}=684)\end{array}$ & $\begin{array}{c}\text { OR } \\
(95 \% \mathrm{Cl})\end{array}$ & P-value \\
\hline MACE & $24 / 312(7.7 \%)$ & $23 / 317(7.3 \%)$ & $47 / 629(7.5 \%)$ & $1.065(0.588-1.930)$ & 0.835 \\
Cardiac mortality & $7 / 312(2.2 \%)$ & $8 / 317(2.5 \%)$ & $15 / 629(2.4 \%)$ & $0.887(0.318-2.475)$ & 0.818 \\
Reinfarction & $3 / 312(1.0 \%)$ & $2 / 317(0.6 \%)$ & $5 / 629(0.8 \%)$ & $1.529(0.254-9.214)$ & 0.684 \\
Total Mortality & $11 / 312(3.5 \%)$ & $11 / 317(3.5 \%)$ & $22 / 629(3.5 \%)$ & $1.017(0.434-2.380)$ & 0.970 \\
ICD implantation & $8 / 312(2.6 \%)$ & $4 / 317(1.3 \%)$ & $12 / 629(1.9 \%)$ & $2.059(0.614-6.909)$ & 0.233 \\
Hospitalisation for Heart Failure & $4 / 312(1.3 \%)$ & $3 / 317(0.9 \%)$ & $7 / 629(1.1 \%)$ & $1.359(0.302-6.124)$ & 0.688 \\
Cardiac mortality and & $11 / 312(3.5 \%)$ & $11 / 317(3.5 \%)$ & $22 / 629(3.5 \%)$ & $1.017(0.434-2.380)$ & 0.970 \\
hospitalization for heart failure & & & & & \\
\hline
\end{tabular}

Subgroup analyses concerning MACE in prespecified subgroups did also not differ between the metoprolol and placebo group. (figure 2 .) MACE rate between very early presenters $(<3$ hours) compared to patients presenting later (>3 hours) were the same: $20 / 225$ (8.9\%) in the metoprolol group vs $17 / 218(7.8 \%)$ in the placebo group in very early presenters, compared to $1 / 63(1.6 \%)$ and $5 / 65(7.7 \%)$ in late presenters. 


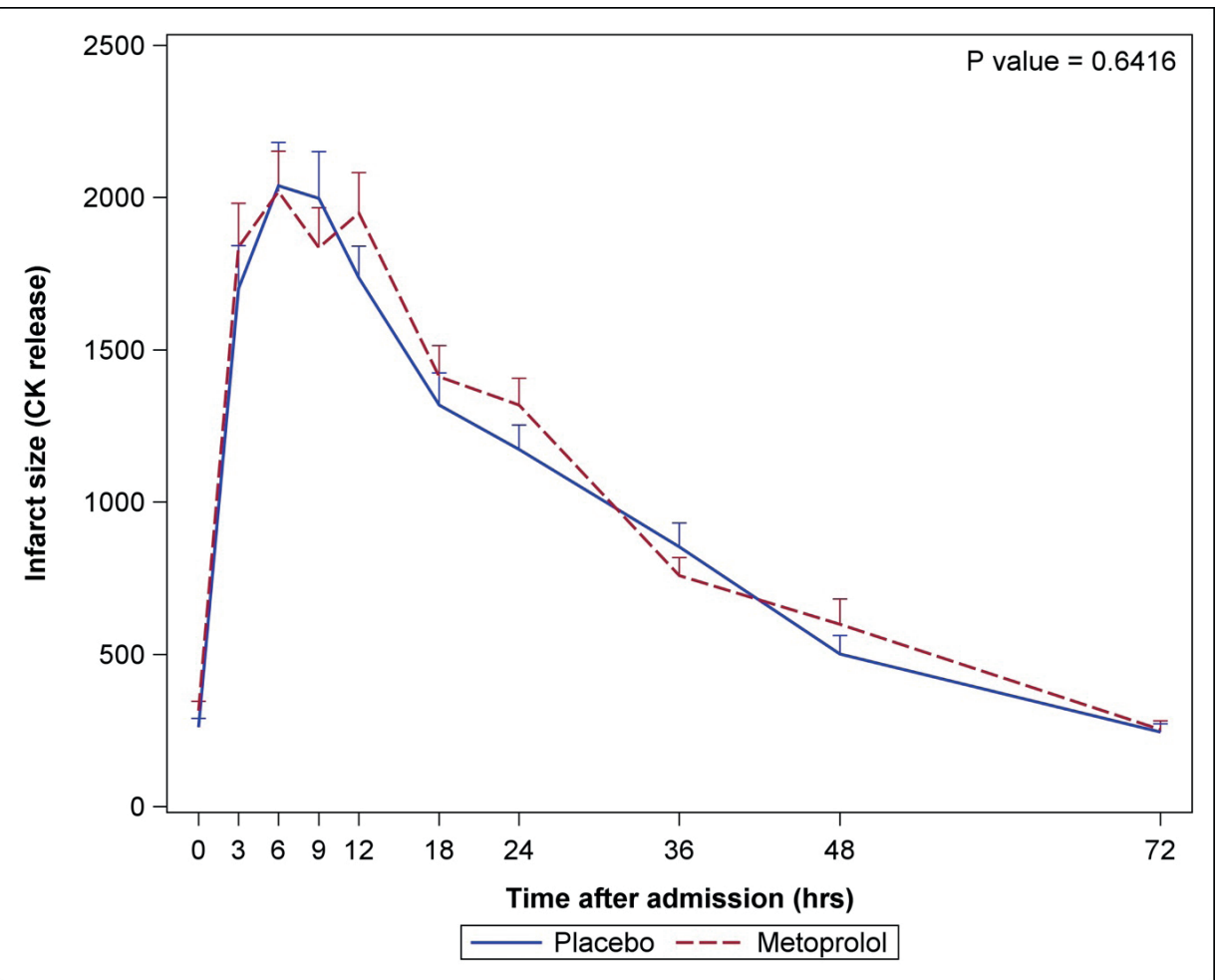

\section{DISCUSSION}

This planned secondary analysis of the Early-BAMI trial presenting the one-year clinical follow-up found no difference in MACE, re-admission for heart failure nor ICD implantation. These results are in line with the previously reported lack of difference in the primary endpoint (infarct size) of the Early-BAMI trial and confirm that metoprolol administered at the prespecified time and dose has no beneficial nor harmful effect on long-term prognosis.

However, early administration before reperfusion is still controversial because of conflicting results of the COMMIT (efficacy and safety of adding Clopidogrel to aspirin or use of metoprolol in myocardial infarction) trial, the METOCARD-CNIC (Effect of metoprolol in Cardioprotection During an Acute Myocardial Infarction) trial and our Early-BAMI trial. $(1,3,4)$ In the COMMIT CC2 trial $(n=45,825)$, intravenous metoprolol $3 \times 5 \mathrm{mg}$ intravenous followed by oral administration up to 4 weeks did not improve survival in STEMI patients. (4) However, this was mainly caused by a higher incidence of cardiogenic shock in patients treated by early beta-blocker, possibly due to inclusion of patients with heart failure. In the current era of primary $\mathrm{PCl}$, the METOCARD-CNIC trial showed reduced infarct size and increased LV ejection fraction in STEMI patients treated with early intravenous metoprolol. (3) However, this 
study had a relatively small sample size $(\mathrm{N}=270)$, was not blinded, nor placebo controlled, and included a selected patient group (anterior STEMI presenting $<6$ hours from symptom onset). The Early-BAMI trial included all patients with STEMI, with a double-blinded, placebo-controlled design, and could not confirm the results of METOCARD-CNIC. One possible explanation can be the difference in infarct size between the two trials: the smaller the infarction size, the less likely an additional treatment effect can be demonstrated. The average infarct size (infarcted myocardium, \% LV) in the METOCARD-CNIC trial was $21.2 \%$ in patients treated with iv metoprolol, compared to $15.3 \%$ in the Early-BAMI trial. Another explanation can be the dose of the metoprolol. In METOCARD-CNIC the dose was higher: up to 3 times $5 \mathrm{mg}$ (15 mg target dose), compared to two times $5 \mathrm{mg}$ (10 mg target dose) in the Early-BAMI. A third explanation can be that $18.8 \%$ of patients in the Early-BAMI trial were on long term beta-blocker treatment before admission, whereas long term beta-blocker treatment was an exclusion criteria in the METOCARD trial. A fourth explanation can be that early beta-blocker treatment may be beneficial in patient with anterior location infarction, and less beneficial of even harmful in patient with inferior location. (6) A final potential reason could be the timing of metoprolol administration: a subanalysis of the METOCARD-CNIC trial (5), showed that only patients receiving i.v. metoprolol long before reperfusion had a reduction in infarct size. In the Early-BAMI trial, the second $5 \mathrm{mg}$ bolus was administered per protocol immediately before catheterization in the cath-lab.

The Early-BAMI trial has several limitations. The most important limitation is that the study was not powered with respect to clinical outcome. The smaller than expected infarct size and the small number of event rates as the major cause. Despite these limitations, the Early-BAMI trial is still the largest trial of its kind, with pre-hospital administration of iv beta-blockade in STEMI patients with a double-blinded, placebo-controlled design. Based on our data, and the conflicting results with previous trials, additional randomized trials are needed to clarify whether early pre-reperfusion beta-blocker treatment has any effect in these patients. The safety profile and low cost encourage the performance of additional larger trials in this regard.

\section{IMPACT ON DAILY PRACTICE}

Early diagnosis and treatment have improved outcome in patients with STEMI. But additional treatment strategies might further improve outcome in these patients. Beta-blockers have been proposed to limit myocardial necrosis and might have a cardioprotective capacity during STEMI. We have demonstrated that early beta-blocker administration in STEMI does not reduce infarct size, MACE-rate or rehospitalization for heart failure. However, they reduce malignant arrhythmias and also do no harm if administered in STEMI patients are not in 
shock. So, beta-blockers remain to have a class lla recommendation in the STEMI guidelines and could be considered in high risk STEMI patients who are not in cardiogenic shock. 


\section{REFERENCES}

1. Roolvink V, Ibanez B, Ottervanger JP et al. Early Intravenous Beta-Blockers in Patients With STSegment Elevation Myocardial Infarction Before Primary Percutaneous Coronary Intervention. J Am Coll Cardiol 2016;67:2705-2715.

2. Roolvink V, Rasoul S, Ottervanger JP et al. Rationale and design of a double-blind, multicenter, randomized, placebo-controlled clinical trial of early administration of intravenous beta-blockers in patients with ST-elevation myocardial infarction before primary percutaneous coronary intervention: EARLY beta-blocker administration before primary PCI in patients with ST-elevation myocardial infarction trial. Am Heart J 2014;168:661-6.

3. Ibanez B, Macaya C, Sanchez-Brunete $V$ et al. Effect of early metoprolol on infarct size in STsegment-elevation myocardial infarction patients undergoing primary percutaneous coronary intervention: the Effect of Metoprolol in Cardioprotection During an Acute Myocardial Infarction (METOCARD-CNIC) trial. Circulation 2013;128:1495-503.

4. Chen ZM, Pan HC, Chen YP et al. Early intravenous then oral metoprolol in 45,852 patients with acute myocardial infarction: randomised placebo-controlled international trial. Lancet 2005;366:1622-32

5. Garcia-Ruiz JM, Fernandez-Jimenez R, Garcia-Alvarez A et al. Impact on the Timing of Metoprolol Administration During STEMI on STEMI on Infarct Size and Ventricular Function. J Am Coll Cardiol 2016;67:2093-104 




\section{Early intravenous beta-blockers in patients undergoing primary percutaneous coronary intervention for ST-segment elevation myocardial infarction. A patient-pooled meta- analysis of randomized clinical trials.}

Eurolntervention J, 2018, submitted

Peter Damman, Vincent Roolvink, Niels PG Hoedemaker,

Robbert J de Winter, Niels van Royen, Valentin Fuster, José M García-Ruiz, Fikret Er, Natig Gassanov, Kenji Hanada, Ken Okumura, Borja Ibáñez, Arnoud W van 't Hof. 


\section{ABSTRACT.}

\section{Aims}

Conflicting evidence is available on the efficacy and safety of early intravenous beta-blockers before primary percutaneous coronary intervention (PCI) for ST-segment elevation myocardial infarction (STEMI). We performed a patient-pooled meta-analysis of trials comparing early intravenous beta-blockers with placebo in STEMI patients undergoing primary PCI.

\section{Methods and Results}

Four randomized trials including a total of 1149 patients were included. Outcomes included enzymatic infarct size, ejection fraction at follow-up, a composite of 1-year death or Ml, and safety outcomes (composite of cardiogenic shock, symptomatic bradycardia or hypotension up to discharge). No difference was observed in enzymatic infarct size. Ejection fraction at six months after STEMI was significantly higher in patients treated with early intravenous betablockade $(52.7 \%$ versus $50.0 \%$ in the control group, $\mathrm{P}=0.03)$. At one-year follow-up death or $\mathrm{Ml}$ occurred in $4.6 \%$ of the beta-blocker group and $4.9 \%$ of the control group $(p=0.89)$. No difference was observed in the safety outcome up to discharge.

\section{Conclusion}

In STEMI patients undergoing primary $\mathrm{PCl}$, the use of early intravenous beta-blockers was safe, with an in increase six-month ejection fraction. No difference was observed in 1-year outcomes. 


\section{INTRODUCTION}

Primary percutaneous coronary intervention $(\mathrm{PCI})$ is the preferred treatment in patients with ST-segment elevation myocardial infarction (STEMI). Although there have been large improvements in outcomes of these patients, subgroups at high risk for mortality remain.(1) The extent of myocardial necrosis / infarct size after STEMI is a well-known predictor for adverse outcomes including mortality.(2) An early experimental study in dogs has demonstrated that treatment with propranolol before coronary ligation was associated with a reduced infarct size.(3) In patients, multiple randomized controlled trials have been performed evaluating the efficacy and safety of intravenous beta-blockers before primary PCI for STEMI, with inconsistent short-term results.(4) This could possibly be explained by differences in time to treatment, heart rate before and after treatment. The objective of this patient-pooled meta-analysis was to evaluate the short-term infarct size and one-year clinical outcomes of intravenous beta-blockers in STEMI patients undergoing primary $\mathrm{PCI}$.

\section{METHODS}

\section{Objective}

The main objective of the current patient-pooled meta-analysis was to assess the effect of early beta-blockers on one-year mortality and the composite of death or myocardial infarction (MI) in patients undergoing primary PCI for STEMI. Secondary objectives include the description of other clinical outcomes, secondary laboratory and imaging outcomes, and safety outcomes.

\section{Search strategy and included trials}

We searched electronic databases for randomized trials that compared early beta-blocker use with routine care or placebo in patients with STEMI. We performed a systemic review of the Medline, Web of Science, and Cochrane Register of Controlled Trials databases up to October 2016 with no language restriction using the following key words: "beta-blocker", "adrenergic beta-antagonists", "infarction" and "STEMI". In order to avoid missing relevant studies, references of the identified studies were scrutinized. Studies included in the patient-pooled meta-analysis included randomized controlled trials that were performed in the current primary PCI area. We included the METOCARD-CNIC (Effect of Metoprolol in Cardioprotection During an Acute Myocardial Infarction), BEAT-AMI (BEtA-Blocker Therapy in Acute Myocardial Infarction), EARLY-BAMI (Early Beta-blocker Administration before primary PCI in patients with ST-elevation Myocardial Infarction), and Hanada et al. randomized controlled trials.(5-8) The study design and main results of the included trials have been described previously. 


\section{Setting and data collection}

The principal investigators of the METOCARD-CNIC, BEAT-AMI, EARLY-BAMI and Hanada et al. initiated this collaborative meta-analysis, and a protocol was written summarizing the main pre-specified analyses and a common set of baseline and outcome variables. Individual patient data was provided to form a pooled patient database. The database included core variables on demographics, clinical history, risk factors for coronary artery disease, STEMI timelines, primary $\mathrm{PCl}$ characteristics, laboratory and imaging data, and clinical outcomes. Data from each trial were sent to the coordinating center in Amsterdam. The merged database was checked for completeness and consistency by all participating sites. The corresponding author had full access to all the data in the study and had final responsibility for the decision to submit for publication.

\section{Patients}

Patients included were presenting with STEMI within 6 hours of symptom onset to reperfusion (within 12 hours in EARLY-BAMI) and a Killip class I or II. Exclusion criteria generally included a low systolic blood pressure $(<120 \mathrm{mmHg}$ in METOCARD-CNIC, $<100 \mathrm{mmHg}$ in EARLY-BAMI, mean arterial pressure $<65 \mathrm{mmHg}$ in BEAT-AMI), a heart rate $<60$ beats per minute, and atrioventricular block type II or III.

\section{Study intervention}

The METOCARD-CNIC and EARLY-BAMI trials evaluated pre-reperfusion intravenous betablocker use, the BEAT-AMI evaluated early post-reperfusion intravenous beta-blocker use. In the METOCARD-CNIC trial, patients randomized to intravenous beta-blockers received up to three $5 \mathrm{mg}$ boluses of metoprolol tartrate two minutes apart in the ambulance during transfer to the $\mathrm{PCl}$ center. Patients randomized to intravenous beta-blockers in the EARLYBAMI trial received five mg of intravenous metoprolol in the ambulance, followed by five mg of intravenous metoprolol at the catheterization laboratory pre-PCI. In BEAT-AMI active therapy consisted of weight-adapted continuous plus additional bolus of esmolol infusion, targeting a heart rate of 60 beats per minute. It was initiated immediately after transfer from the catheterization laboratory to the intensive care unit. Patients randomized to the control arm received a placebo. In the study by Hanada et al, patients were randomized post-PCl, the landiolol group received intravenous infusion of beta-blocker started at three $\mu \mathrm{g}$ per $\mathrm{kg}$ per min without loading and continued for 24 hours. Patients were concomitantly treated according to clinical guidelines in all studies. Generally clinical guidelines recommend the initiation of oral beta-blockers within 12 hours of hospitalization, unless contra-indicated. 


\section{OUTCOMES}

Ventricular arrhythmias were assessed. Infarct size was estimated by enzymatic infarct size (peak value of creatinine kinase, $C K$ isoenzyme $M B$, and troponin). Ejection fraction was assessed by imaging methods (cardiac MR in METOCARDO-CNIC and EARLY-BAMI, echocardiography in BEAT-AMI, and left ventricular angiography in Hanada et al.). The main outcome of the patient-pooled meta-analysis was one-year mortality. Secondary clinical outcomes included the composite of death or Ml and it's individual components death, nonfatal MI. Safety outcomes included the composite of cardiogenic shock, symptomatic bradycardia or hypotension.

\section{Statistical analysis}

We analysed data by the intention-to-treat principle. Baseline and procedural characteristics, and outcomes were tabulated by treatment group. Normally distributed continuous variables were compared with the Student's t test and skewed-distributed with the Wilcoxon ranksum test. Categorical variables were compared with the chi-square test. One-year clinical outcome rates were estimated with the Kaplan-Meier method. Hazard ratios and P-values of the univariable association between randomized treatment and outcomes were derived from Cox regression models. Pre-specified subgroup analyses included outcomes according infarct-related artery, time to reperfusion and heart rate before study treatment. All analyses were performed using SPSS version 20.0.

\section{Role of the funding source}

No funding.

\section{RESULTS}

\section{Baseline characteristics}

The dataset comprised 1150 patients, of whom 572 were originally randomized to early intravenous beta-blockade and 528 to placebo. The median time to follow-up was 365 days (interquartile range 365 to 373). Table 1 shows the baseline characteristics of the study population. The mean age of the population was 61 years, and around three quarters were male. Over $90 \%$ of the patients underwent primary $\mathrm{PCl}$. There were no significant differences in baseline characteristics. Post-treatment heart rate was 70 beats per minute in the intravenous beta-blocker group versus 76 beats per minute in the control group $(p<0.001)$. 
Table 1 - Baseline characteristics

\begin{tabular}{|c|c|c|c|c|c|}
\hline & \multicolumn{2}{|l|}{ Beta-blocker } & \multicolumn{2}{|l|}{ No beta-blocker } & \multirow[b]{2}{*}{$\mathrm{p}$-value } \\
\hline & $n=572$ & $\%$ & $\mathrm{n}=578$ & $\%$ & \\
\hline \multicolumn{6}{|l|}{ Baseline characteristics } \\
\hline Age, year, mean (SD) & $61.2(12.4)$ & & $61.4(12.3)$ & & 0.79 \\
\hline Male, \% & $(451$ /572) & 78.8 & $(449$ /578) & 77.7 & 0.63 \\
\hline BMI, median (IQR) & $26.6(24.6-29.0)$ & & $26.6(24.3-29.4)$ & & 0.57 \\
\hline Hypertension, \% & $(249 / 566)$ & 44.0 & $(248 \quad / 572)$ & 43.4 & 0.83 \\
\hline Diabetes, \% & $(105 / 565)$ & 18.6 & $(113$ /575) & 19.7 & 0.65 \\
\hline Smoking, \% & $(260$ /547) & 47.5 & $(256$ /548) & 46.7 & 0.79 \\
\hline Hyperlipidaemia, \% & $(197 / 559)$ & 35.2 & $(187 / 565)$ & 33.1 & 0.45 \\
\hline Previous MI, \% & $(15$ /429) & 3.5 & $(17$ 1445) & 3.8 & 0.80 \\
\hline Previous PCl, \% & $(30$ 1430) & 7.0 & $(24$ 1446) & 5.4 & 0.33 \\
\hline Previous CABG, \% & $(4 \quad / 430)$ & 0.9 & $(6 \quad 1446)$ & 1.3 & 0.56 \\
\hline Prior beta-blocker use, $\%$ & $(54$ /329) & 16.4 & $(60$ 1343) & 17.5 & 0.71 \\
\hline \multicolumn{6}{|l|}{ Clinical presentation } \\
\hline Killip class I, \% & $(445 \quad / 472)$ & 94.3 & $(447 \quad / 485)$ & 92.2 & 0.19 \\
\hline Killip class II, \% & $(24$ 1472) & 5.1 & $(31$ 1485) & 6.4 & 0.38 \\
\hline Baseline SBP, mmHg, mean (SD) & $143.8(23.3)$ & & $143.5(23.3)$ & & 0.86 \\
\hline Baseline DBP, mmHg, mean (SD) & $87.8(15.8)$ & & $87.8(16.7)$ & & 0.98 \\
\hline Pre-treatment $\mathrm{HR}$, beat/min, median (IQR) & $77.0(69.0-87.5)$ & & $79.0(70.0-89.0)$ & & 0.25 \\
\hline 24 hour SBP, mmHg, mean (SD) & $131.0(22.2)$ & & $134.1(25.5)$ & & 0.04 \\
\hline 24 hour DBP, mmHg, mean & $79.4(15.1)$ & & $79.8(16.0)$ & & 0.74 \\
\hline 24 hour HR, beat/min, median (IQR) & $70.0(62.0-80.0)$ & & $76.0(68.0-86.0)$ & & $<0.001$ \\
\hline \multicolumn{6}{|l|}{ Hospitalisation } \\
\hline Reperfusion time, minutes, median (IQR) & $182(137-258)$ & & $183(130-259)$ & & 0.58 \\
\hline \multicolumn{6}{|l|}{ Infarct related artery, \% } \\
\hline LAD, \% & $(316 \quad / 535)$ & 59.1 & $(337 \quad 1540)$ & 62.4 & 0.26 \\
\hline $\mathrm{RCX}, \%$ & $(61 \quad / 535)$ & 11.4 & $(56 \quad / 540)$ & 10.4 & 0.59 \\
\hline RCA, \% & $(155$ /535) & 29.0 & $(142 \quad / 540)$ & 26.3 & 0.33 \\
\hline \multicolumn{6}{|l|}{ No. Diseased coronary vessels, \% } \\
\hline $1, \%$ & $(225$ /427) & 52.7 & $(254$ /439) & 57.9 & 0.13 \\
\hline $2, \%$ & $(131$ /427) & 30.7 & (94 1439) & 21.4 & 0.002 \\
\hline $3, \%$ & $(55$ 1427) & 12.9 & $(70$ 1439) & 15.9 & 0.20 \\
\hline Primary $\mathrm{PCl}$ during admission, \% & $(529 / 561)$ & 94.3 & $(528$ /569) & 92.8 & 0.31 \\
\hline CABG during admission, \% & $(12$ /572) & 2.1 & $(22$ /578) & 3.8 & 0.09 \\
\hline Beta-blocker at discharge, \% & $(420 \quad / 515)$ & 81.6 & $(413 \quad / 519)$ & 79.6 & 0.42 \\
\hline Admission length, days, median & & & & & \\
\hline
\end{tabular}

BMI: body mass index, CABG: coronary artery bypass grafting, DBP: diastolic blood pressure, MI: myocardial infarction, IQR: interquartile range, PCI: percutaneous coronary intervention, SBP: systolic blood pressure, SD: standard deviation, 


\section{Outcomes}

The laboratory and imaging outcomes are shown in Table 2. With regards to cardiac biomarkers, no significant difference was observed in peak CK, CK-MB and or high-sensitive Troponin. Ejection fraction at six months after STEMI was significantly higher in patients treated with early intravenous beta-blockade $(52.7 \%$ versus $50.0 \%$ in the control group, $\mathrm{P}=0.03)$.

Table 2 - Laboratory and imaging outcomes

\begin{tabular}{llllll}
\hline & Beta-blocker & & No beta-blocker & & p-value \\
\cline { 2 - 6 } & $\mathbf{n}=572$ & $\mathbf{n}$ & $\mathbf{n}=\mathbf{5 7 8}$ & $\mathbf{n}$ & \\
\hline Ejection fraction & & 316 & $49.8(11.7)$ & 332 & 0.15 \\
Ejection fraction \% at 1 month, mean (SD) & $51.1(11.4)$ & 189 & $50.0(12.4)$ & 191 & 0.03 \\
Ejection fraction \% at 6 months, mean (SD) & $52.7(11.2)$ & & & & \\
Laboratory assessments & & 558 & $1650(513-3589)$ & 561 & 0.29 \\
CK peak, U/L, median (IQR) & $1427(471-3232)$ & 370 & $149(53-300)$ & 384 & 0.98 \\
CK-MB peak, U/L, mean & $145(60-321)$ & 341 & $960(50-4923)$ & 354 & 0.96 \\
Troponin peak, ng/L, mean & $1200(62-4800)$ & 29 & $63(21-133)$ & 34 & 0.82 \\
Troponin peak, ug/L, mean & $45(11-211)$ & 204 & $2561(929-5498)$ & 202 & 0.45 \\
CK-MB AUC, U/L, mean & $2610(926-5885)$ & 226 & $52825(13580-133546)$ & 228 & 0.93 \\
\hline Troponin AUC, ng/L, mean & $51230(8652-153824)$ & & & \\
\hline
\end{tabular}

AUC: area under the curve, IQR: interquartile range, SD: standard deviation,

The main clinical/efficacy outcome death or MI occurred in $4.6 \%$ of the beta-blocker group and $4.9 \%$ of the control group $(p=0.89)$. The Kaplan-Meier curves are shown in Figure 1. The other clinical outcomes at one-year follow-up are presented in Table 3. No difference was observed in the individual outcomes death, cardiac death, or myocardial infarction. The use of intravenous beta-blocker appeared safe, with comparable safety outcome rates (the composite of cardiogenic shock, symptomatic bradycardia or hypotension).

\section{Relation between beta-blockers and outcomes in subgroups}

The unadjusted hazard ratio for one-year death of $\mathrm{Ml}$ was 0.89 (95\% confidence interval 0.53-1.74, $\mathrm{P}=0.89$ ) when comparing intravenous beta-blockers versus control. After adjustment for pre-specified heart-rate pre-treatment, culprit lesion (including anterior versus non-anterior $\mathrm{MI}$ ) and time to treatment, the adjusted hazard ratio was 0.91 (95\% confidence interval $0.45-1.83, P=0.79$ ). Furthermore, there was no interaction with these pre-specified variables. 


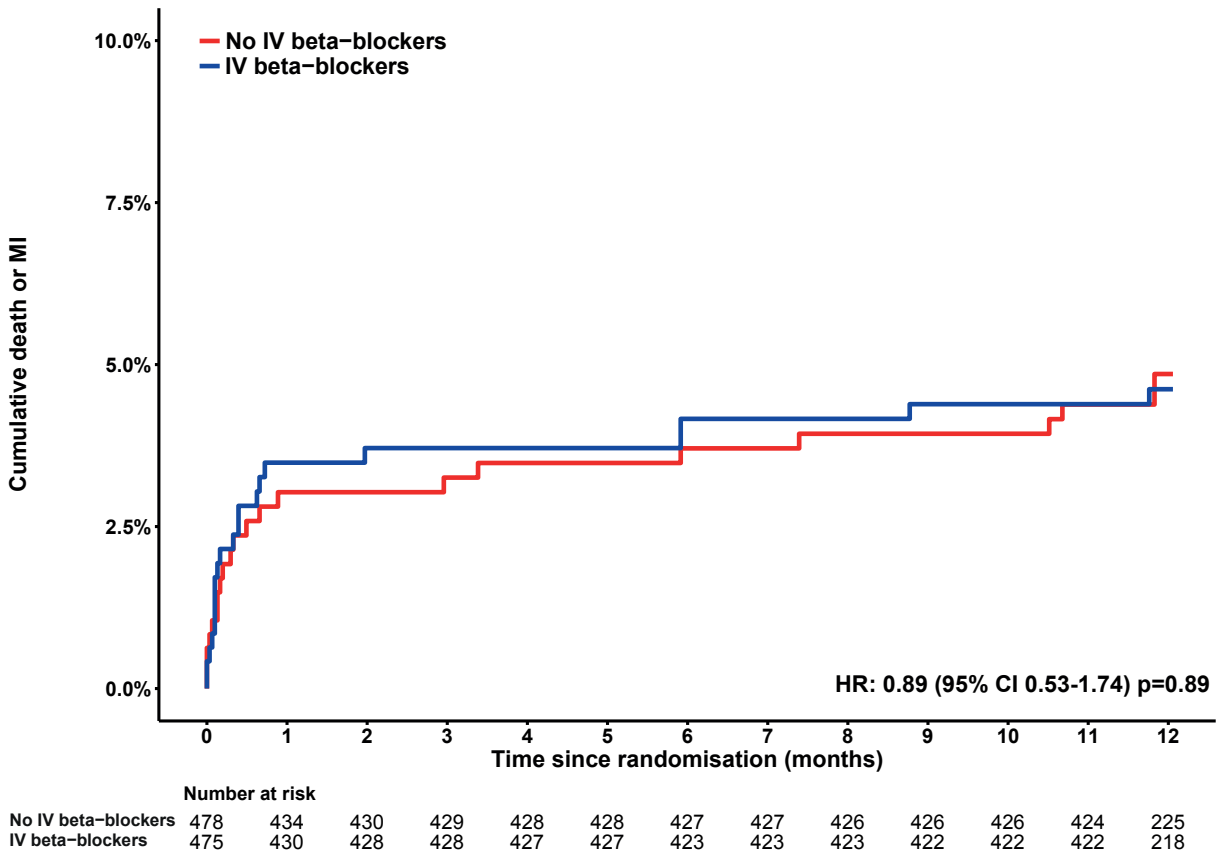

Figure 1 - One-year composite outcome of death or Ml

Table 3 - Clinical outcomes

\begin{tabular}{llllll}
\hline & Beta-blocker & \multicolumn{2}{c}{ No beta-blocker } & & p-value \\
\cline { 2 - 6 } & $\mathrm{n}=5 \mathbf{5 7 2}$ & $\%$ & $\mathrm{n}=578$ & $\%$ & \\
\hline One-year efficacy outcomes & & & & & \\
Death or myocardial infarction & $21 / 475$ & 4.6 & $22 / 478$ & 4.9 & 0.89 \\
All-cause mortality & $16 / 524$ & 3.2 & $19 / 529$ & 3.9 & 0.62 \\
Cardiac death & $11 / 524$ & 2.2 & $14 / 529$ & 2.8 & 0.56 \\
Myocardial infarction & $5 / 475$ & 1.1 & $4 / 478$ & 0.9 & 0.74 \\
Safety outcome up to discharge & $22 / 520$ & 4.2 & $19 / 525$ & 3.6 & 0.62 \\
Ventricular tachycardia up to discharge & $46 / 526$ & 8.7 & $38 / 521$ & 7.3 & 0.39 \\
\hline
\end{tabular}

Safety outcome is the composite of cardiogenic shock, symptomatic bradycardia or hypotension

One-year efficacy outcomes are Kaplan-Meier estimates, compared with a log-rank test. Safety outcome and ventricular tachycardia are percentages, compared with a Chi-square test.

\section{DISCUSSION}

Several conclusions can be drawn from the current patient-pooled meta-analysis comparing early intravenous beta-blockers with placebo in STEMI patients undergoing primary PCI. First, the use of intravenous beta-blockers was safe, no increased rate of cardiogenic shock, symptomatic bradycardia or hypotension was observed. At six months follow-up there was a 
small but significant increase in ejection fraction with beta-blockers. The increase in ejection fraction did not result in improved clinical outcomes, death or MI was similar at one-year follow-up. Finally, results were comparable when heart rate, time to treatment and infarctrelated artery were taken into account.

\section{Included trials}

There is a discrepancy in the efficacy results of the largest two trials. In METOCARD-CNIC, there was a reduction in CMR infarct size at one week and six months with early intravenous beta-blockade. 5 No difference in infarct size was observed at one month in the EARLY-BAMI trial.(7) This might be explained by the following factors. First, infarct size was smaller in the EARLY-BAMI trial, making it less likely of showing a reduction with early beta-blockade. Second, the dose of metoprolol used in the METOCARD-CNIC was $15 \mathrm{mg}$, while $10 \mathrm{mg}$ was used in the EARLY-BAMI trial. A third explanation might be related to timing of metoprolol administration. In a subanalysis of METOCARD-CNIC, longer exposure to intravenous beta-blockade was associated with smaller infarct size. In EARLY-BAMI, the second bolus of medication was administered just before PCI. In BEAT-AMI, esmolol treatment statistically significantly decreased cardiac Troponin, CK and CK-MB as surrogate markers for myocardial injury. In the trial by Hanada et al., early intravenous administration of landiolol was associated with an improvement in 6-month ejection fraction. With regards to safety, all four trials show comparable results.

\section{Pathophysiological effects of beta-blockers}

A potential beneficial effect of beta-blockers might be explained by the following mechanisms. In general, blockade of beta-1 receptors cause a reduction of heart rate, myocardial contractility, and lowered systemic blood pressure; resulting in a reduced myocardial workload and oxygen demand. This has been demonstrated in porcine models, in which intravenous metoprolol during coronary occlusion and before mechanical reperfusion was a highly effective cardioprotective agent, resulting in a $27 \%$ smaller MI than placebo, despite an initially equivalent amount of myocardium at risk.(9) This cardioprotective effect was independent of its negative chronotropic effects. It has to be noted that the beneficial effect was independent of the heart rate. Furthermore, prolongation of the diastolic phase caused by the chronotropic effects of beta-blockers may increase myocardial perfusion.

Recently, a study has shown that neutrophil stunning by metoprolol might be an explanation for a reduced infarct size.(10) It has been previously shown that infarct size is related to a pro-inflammatory response occurring during and post-MI.(11) In both human and animal ischemia-reperfusion models, metoprolol inhibits the potential deleterious neutrophil inflammatory response. 
The reduction in ventricular arrhythmias might be related to the stabilizing effect on the myocardial cell membrane and the inhibition of the re-entrant pathways as a consequence of the infarcted myocardium.(12)

\section{Safety}

The safety outcomes of the current analysis was a composite of cardiogenic shock, symptomatic bradycardia or hypotension. Physicians might be reluctant to use early intravenous betablockers because of the potential occurrence of these outcomes. However, up to discharge, no significant increase was observed in the safety outcome in the intravenous beta-blocker group in more than 1000 randomized patients. Therefore, we conclude that this therapy is safe in the setting of primary PCI for STEMI.

\section{Beneficial effects}

The most important beneficial effect was the increase in ejection fraction at six-month followup. We hypothesize that this is explained by a reduced total infarct size. The cardiac necrosis markers do not support this explanation, although there might be several explanations for this discrepancy. First, different cardiac necrosis markers were used in the trials. Another possible explanation might be that ejection fraction at six months is a better surrogate for infarct size than peak cardiac necrosis markers. Finally, the observed benefit might be a spurious finding, with a ejection fraction difference of $2.7 \%$ in favor of the intravenous beta-blocker group. Ultimately, the improved ejection fraction did not lead to better clinical outcomes. Longer follow-up might be necessary to reveal differences in clinical outcomes.

\section{Implications}

Based on the current available evidence, the latest European Society of Cardiology guidelines for STEMI state that early administration of intravenous beta-blockers at the time of presentation followed by oral beta-blockers should be considered in haemodynamically stable patients undergoing primary $\mathrm{PCl}$.(13) This excludes patients with signs of acute heart failure or a systolic blood pressure lower then $120 \mathrm{mmHg}$. Our current patient-pooled meta-analysis enforces this statement.

\section{Limitations}

A number of limitations deserve mention. First left ventricular ejection fraction was assessed using different imaging modalities in the various trials. However, this is true for both treatment strategies. Second, different beta-blockers were used in the various trials, with metoprolol being in used in the largest two, and landiolol and esmolol in the smaller trials. 


\section{Conclusion and future recommendations}

In STEMI patients undergoing primary $\mathrm{PCl}$, the use of early intravenous beta-blockers was safe, with an in increase six-month ejection fraction. No difference was observed in one-year outcomes. Given the apparent safety of intravenous metoprolol when administered in STEMI patients, and potential beneficial effects, a novel trial should be performed comparing the effect of early (preferably in the ambulance) high-dose $15 \mathrm{mg}$ metoprolol versus placebo on clinical outcomes. If successful, this could result in an inexpensive treatment for STEMI patients undergoing primary $\mathrm{PCl}$ in absence of cardiogenic shock at presentation. 


\section{REFERENCES}

1. Damman P, Beijk MA, Kuijt WJ, Verouden NJ, van Geloven N, Henriques JP, Baan J, Vis MM, Meuwissen M, van Straalen JP, Fischer J, Koch KT, Piek JJ, Tijssen JG, de Winter RJ. Multiple biomarkers at admission significantly improve the prediction of mortality in patients undergoing primary percutaneous coronary intervention for acute ST-segment elevation myocardial infarction. J Am Coll Cardiol. 2011;57:29-36.

2. Stone GW, Selker HP, Thiele H, Patel MR, Udelson JE, Ohman EM, Maehara A, Eitel I, Granger CB, Jenkins PL, Nichols M, Ben-Yehuda O. Relationship Between Infarct Size and Outcomes Following Primary PCl: Patient-Level Analysis From 10 Randomized Trials. J Am Coll Cardiol 2016;67:167483.

3. Rasmussen $M M$, Reimer $K A$, Kloner RA, Jennings $R B$. Infarct size reduction by propranolol before and after coronary ligation in dogs. Circulation 1977;56:794-8.

4. Elgendy IY, Elgendy AY, Mahmoud AN, Mansoor H, Mojadidi MK, Bavry AA. Intravenous $\beta$-blockers for patients undergoing primary percutaneous coronary intervention: A meta-analysis of randomized trials. Int J Cardiol 2016;223:891-97.

5. Ibanez B, Macaya C, Sánchez-Brunete V, Pizarro G, Fernández-Friera L, Mateos A, FernándezOrtiz A, García-Ruiz JM, García-Álvarez A, Iñiguez A, Jiménez-Borreguero J, López-Romero P, Fernández-Jiménez R, Goicolea J, Ruiz-Mateos B, Bastante T, Arias M, Iglesias-Vázquez JA, Rodriguez MD, Escalera N, Acebal C, Cabrera JA, Valenciano J, Pérez de Prado A, Fernández-Campos MJ, Casado I, García-Rubira JC, García-Prieto J, Sanz-Rosa D, Cuellas C, Hernández-Antolín R, Albarrán A, Fernández-Vázquez F, de la Torre-Hernández JM, Pocock S, Sanz G, Fuster V. Effect of early metoprolol on infarct size in ST-segment-elevation myocardial infarction patients undergoing primary percutaneous coronary intervention: the effect of Metoprolol in Cardioprotection During an Acute Myocardial Infarction (METOCARD-CNIC) trial. Circulation 2013;128:1495-1503.

6. Er F, Dahlem KM, Nia AM, Erdmann E, Waltenberger J, Hellmich M, Kuhr K, Le MT, Herrfurth T, Taghiyev Z, Biesenbach E, Yüksel D, Eran-Ergöknil A, Vanezi M, Caglayan E, Gassanov N. Randomized control of sympathetic drive with continuous intravenous esmolol in patients with acute ST-segment elevation myocardial infarction: the BEtA-Blocker Therapy in Acute Myocardial Infarction (BEATAMI) Trial. JACC Cardiovasc Interv 2016;9:231-40.

7. Roolvink V, Ibáñez B, Ottervanger JP, Pizarro G, van Royen N, Mateos A, Dambrink JE, Escalera $N$, Lipsic E, Albarran A, Fernández-Ortiz A, Fernández-Avilés F, Goicolea J, Botas J, Remkes W, Hernandez-Jaras V, Kedhi E, Zamorano JL, Navarro F, Alfonso F, García-Lledó A, Alonso J, van Leeuwen M, Nijveldt R, Postma S, Kolkman E, Gosselink M, de Smet B, Rasoul S, Piek JJ, Fuster $V$, van 't Hof AWJ; EARLY-BAMI Investigators. Early administration of intravenous betablockers in patients with ST-elevation myocardial infarction before primary PCI. J Am Coll Cardiol 2016;67:2705-15.

8. Hanada K, Higuma T, Nishizaki F, Sukekawa T, Yokota T, Yamada M, Saito S, Kushibiki M, Oikawa $K$, Abe N, Tomita H, Osanai T, Okumura K. Randomized study on the efficacy and safety of landiolol, an ultra-short-acting $\beta 1$-adrenergic blocker, in patients with acute myocardial infarction undergoing primary percutaneous coronary intervention, Circ J 2012;67:439-45.

9. Ibanez B, Prat-González S, Speidl WS, Vilahur G, Pinero A, Cimmino G, García MJ, Fuster V, Sanz $J$, Badimon JJ.Early metoprolol administration before coronary reperfusion results in increased myocardial salvage: analysis of ischemic myocardium at risk using cardiac magnetic resonance. Circulation 2007;115:2909-16. 
10. García-Prieto J, Villena-Gutiérrez R, Gómez M, Bernardo E, Pun-García A, García-Lunar I, Crainiciuc G, Fernández-Jiménez R, Sreeramkumar V, Bourio-Martínez R, García-Ruiz JM, Del Valle AS, Sanz-Rosa D, Pizarro G, Fernández-Ortiz A, Hidalgo A, Fuster V, Ibanez B1. Neutrophil stunning by metoprolol reduces infarct size. Nat Commun 2017;8:147-80.

11. van der Laan $A M$, Hirsch $A$, Robbers $L F$, Nijveldt $R$, Lommerse I, Delewi $R$, van der Vleuten PA, Biemond BJ, Zwaginga JJ, van der Giessen WJ, Zijlstra F, van Rossum AC, Voermans C, van der Schoot CE, Piek JJ.. A proinflammatory monocyte response is associated with myocardial injury and impaired functional outcome in patients with ST-segment elevation myocardial infarction: monocytes and myocardial infarction. Am Heart J 2012;163:57-65.

12. Norris RM, Barnaby PF, Brown MA, Geary GG, Clarke ED, Logan RL, Sharpe DN. Prevention of ventricular fibrillation during acute myocardial infarction by intravenous propranolol. Lancet 1984:2:883-6.

13. Ibanez B, James S, Agewall S, Antunes MJ, Bucciarelli-Ducci C, Bueno H, Caforio ALP, Crea F, Goudevenos JA, Halvorsen S, Hindricks G, Kastrati A, Lenzen MJ, Prescott E, Roffi M, Valgimigli $M$, Varenhorst C, Vranckx P, Widimský P; ESC Scientific Document Group. The Task Force for the management of acute myocardial infarction in patients presenting with ST-segment elevation of the European Society of Cardiology (ESC). 2017 ESC Guidelines for the management of acute myocardial infarction in patients presenting with ST-segment elevation. Eur Heart J 2017 ahead of print 



\section{Summary, conclusions and future perspectives}

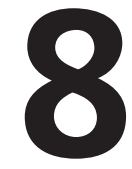





\section{SUMMARY AND CONCLUSIONS}

This thesis addresses the effect of beta-blockers on infarct size, clinical endpoints and safety profile, when used in a pre-hospital setting before reperfusion therapy for ST elevation Myocardial Infarction. The goals of this thesis were to investigate the impact of intravenous beta-blocker administration before primary $\mathrm{PCl}$ on myocardial infarct size, the short- and long-term clinical outcome and its safety profile.

In chapter 1, a brief introduction about the subject and the background of the thesis is given. Myocardial infarct size is a major determinant of morbidity and mortality in patient with ST-segment myocardial infarction. Oxygen demand of the heart is higher when the heartrate increases. So, in theory, lowering oxygen demand by lowering the heartrate in an ischemic situation can be beneficial. However, whether beta-blocker administration before reperfusion reduces myocardial infarct size remains to be elucidated. Further research to assess the effect of early, prehospital administration of beta-blockers on myocardial infarct size and long term clinical outcome is mandatory.

In chapter 2, an overview of early beta-blocker treatment in STEMI patients in the thrombolytic era is summarized. Also, the results of a multicenter, nonrandomized, prospective observational cohort study in which STEMI patients were treated with immediate or delayed administration of oral bisoprolol $2.5 \mathrm{mg}$ are discussed. This study is one of the first trials in the primary $\mathrm{PCl}$ era. A significant reduction of all-cause mortality of immediate compared with delayed beta-blocker treatment $(10.7 \%$ vs. $19.2 \%)$ was demonstrated. Multivariable regression analysis identified immediate beta-blocker therapy as in-depended protective treatment for all-cause mortality. The importance of this study lies primarily in the comparison of immediate (<30 min) vs delayed beta-blocker administration.

In chapter 3, the rationale and design of the Early-BAMI trial is described. This trial investigates the impact of intravenous metoprolol administration before primary PCI for STEMI on myocardial infarct size as measured with MRI at 30 days. It was designed as a multinational, multicenter, double-blind, placebo-controlled, randomized trial, in which patients with symptoms and signs of STEMI and transferred to a hospital for primary $\mathrm{PCl}$ and would be randomized in a 1:1 fashion to intravenous metoprolol (5 mg twice daily) administration or placebo. Before admission, study treatment would be started as soon as possible after the diagnosis of STEMI. After admission, primary PCI would be performed as per standard of care. After primary $\mathrm{PCl}$, medical treatment would occur as per current guidelines in all patients, including the use of oral $\beta$-blockers. The primary end point was the myocardial infarct size as assessed by MRI at 30 days. 
In chapter 4, the association between chronic beta-blocker treatment and haemodynamics at admission in patients with STEMI treated by primary percutaneous coronary intervention is assessed with particularly the potential risk of cardiogenic shock (CS) and pre-shock in those with chronic beta-blocker treatment. A total of 4907 patients with STEMI treated with PPCI, were included in the study. 1148 patients (23.3\%) were on chronic beta-blocker treatment. CS was observed in 264 patients (5.3\%). Pre-shock was defined as a Shock Index $\geq 0.7$ and was observed in 1022 patients (20.8\%). The risk of CS in patients with chronic beta-blocker treatment was not increased. Chronic beta-blocker treatment was also not associated with an increased risk of pre-shock (adjusted HR 0.86, 95\% Cl $0.68-1.07, \mathrm{p}=0.19$ ). Also, after propensity score matched analysis, there was no increased risk of CS or pre-shock in patients with chronic beta-blocker treatment (respectively HR 0.97, 95\% Cl $0.61-1.51, p=0.88$ and HR $0.82,95 \% \mathrm{Cl} 0.65-1.06, p=0.12$ ). These findings show that chronic beta-blocker treatment is not associated with an increased risk of cardiogenic shock or pre-shock in STEMI patients.

Chapter 5, presents the data of the Early-BAMI trial, investigating the impact of intravenous metoprolol administration before primary PCI for STEMI on myocardial infarct size as measured with MRI at 30 days and clinical outcome. In this first double-blinded, placebo-controlled international multicenter study, we tested the effect of early i.v. beta-blockers before PPCI in a general STEMI population presenting $<12 \mathrm{~h}$ from symptom onset, Killip I-II, without AV block. Patients were 1:1 randomized to i.v. metoprolol (2x5 mg bolus) or matched placebo before primary $\mathrm{PCl}$. Primary endpoint was myocardial infarct size as assessed by magnetic resonance imaging (MRI) at 30 days. Secondary endpoints were enzymatic infarct size and incidence of ventricular arrhythmias. Safety endpoints included symptomatic bradycardia, symptomatic hypotension, and cardiogenic shock. A total of 683 patients (mean age $62 \pm 12$ years, $75 \%$ male) were randomized to metoprolol $(n=336)$ or placebo $(n=346)$. MRI was performed in 342 patients (54.8\%). Infarct size (\% of LV) by MRI did not differ between the metoprolol $(15.3 \pm 11.0 \%)$ and placebo group $(14.9 \pm 11.5 \% p=0.616)$. Peak and area under the creatine kinase (CK) curve did not differ between both groups. Left ventricular ejection fraction by MRI was $51.0 \pm 10.9 \%$ in the metoprolol group and $51.6 \pm 10.8 \%$ in the placebo group, $p=0.68$. The incidence of malignant arrhythmias was $3.6 \%$ in the metoprolol group vs $6.9 \%$ in placebo $p=0.05$. The incidence of adverse events was not different between groups. It was concluded that in a non-restricted STEMI population, early intravenous metoprolol before $\mathrm{pPCl}$, was not associated with a reduction in infarct size. Metoprolol reduced the incidence of malignant arrhythmias in the acute phase and was not associated with an increase in adverse events.

Chapter 6 describes the long (one year) clinical outcome of the EARLY-BAMI (Early intravenous beta-blockers in patients with ST-segment elevation myocardial infarction before PPCI) 
trial. One-year clinical outcome was defined by major cardiac adverse event (MACE) rate, defined as cardiac death, nonfatal reinfarction, or target vessel revascularization. One year follow up was obtained in 629 patients (92\%). Mean follow- up time was 374 +/- 20 days in the metoprolol group vs $373+/-23$ days in the placebo group. Incidence of MACE at one year was $7.7 \%$ in the metoprolol group vs $7.3 \%$ in the placebo group. $P=0.835$. It wass concluded that in a nonrestricted STEMI population undergoing $\mathrm{PPCl}$, early pre-hospital iv metoprolol before reperfusion did not result into a reduction in clinical events at one year.

Chapter 7, describes a patient-pooled meta-analysis of randomized clinical trials to evaluating the efficacy and safety of intravenous beta-blockers before primary PCI for STEMI. We searched electronic databases for randomized trials that compared early beta-blocker use with routine care or placebo in patients with STEMI. We performed a systemic review of the Medline, Web of Science, and Cochrane Register of Controlled Trials databases up to October 2016 with no language restriction. In order to avoid missing relevant studies, references of the identified studies were scrutinized. Studies included in the patient-pooled metaanalysis included randomized controlled trials that were performed in the current primary PCI area. We included the METOCARD-CNIC (Effect of Metoprolol in Cardioprotection During an Acute Myocardial Infarction), BEAT-AMI (BEtA-Blocker Therapy in Acute Myocardial Infarction), EARLY-BAMI (Early Beta-blocker Administration before primary $\mathrm{PCl}$ in patients with ST-elevation Myocardial Infarction), and Hanada et al. randomized controlled trials . The dataset comprised 1150 patients, of whom 572 were originally randomized to early intravenous beta-blockade and 528 to placebo. The median time to follow-up was 365 days (interquartile range 365 to 373). The mean age of the population was 61 years, and around three quarters were male. Over $90 \%$ of the patients underwent primary $\mathrm{PCl}$. There were no significant differences in baseline characteristics. With regards to cardiac biomarkers, no significant difference was observed in peak CK, CK-MB and or high-sensitive Troponin. Ejection fraction at six months after STEMI was significantly higher in patients treated with early intravenous beta-blockade (52.7\% versus $50.0 \%$ in the control group, $\mathrm{P}=0.03$ ). The main clinical/efficacy outcome death or Ml occurred in $4.6 \%$ of the beta-blocker group and $4.9 \%$ of the control group $(p=0.89)$.

It was concluded that in STEMI patients undergoing primary PCI, the use of early intravenous beta-blockers was safe, with a possible improvement in six-month ejection fraction. No difference was observed in 1-year outcomes. 


\section{DISCUSSION AND FUTURE PERSPECTIVES}

\section{Discussion}

Since rapid reperfusion of the occluded coronary artery in patients with an acute myocardial infarction is obtained in most patients, further efforts to improve myocardial tissue salvage after an ischemic event are based on limiting infarct size.

Many clinical trials have tried to limit infarct size with various therapy's. Stem cell injection in the infarct tissue, EPO admission shortly after myocardial infarction, and high dose oxygen therapy have all shown disappointing results in lowering infarct size. The potential of betablockers to limit myocardial necrosis was proposed long ago, and most data were from the thrombolytic era with conflicting results. One prospective randomized trial (METOCARD(NIC) in the current $\mathrm{pPCl}$ era showed a reduction in infarct size and increase in LVEF in anterior STEMI patients.

In this thesis, the results from both the Early-BAMI and a meta-analysis showed however no benefit of neither infarct size nor LVEF with early beta-blocker administration in STEMI patients. These conflicting results might be explained by the following factors. First, infarct size was smaller in the Early-BAMI trial, making it less likely that early beta-blockade should reduce infarct size. Second, the dose of metoprolol used in the METOCARD-CNIC was 15mg, while $10 \mathrm{mg}$ was used in the Early-BAMI trial. A third explanation might be related to timing of metoprolol administration. In a subanalysis of METOCARD-CNIC, longer exposure to intravenous beta-blockade was associated with smaller infarct size. In Early-BAMI, the second bolus of medication was administered just before $\mathrm{PCl}$.

\section{Pathophysiological effects of beta-blockers}

A potential beneficial effect of beta-blockers might be explained by the several mechanisms. In general, blockade of beta-1 receptors causes a reduction of both heart rate and myocardial contractility, with lower systemic blood pressure. This results in a reduced myocardial workload and oxygen demand. Furthermore, prolongation of the diastolic phase caused by the chronotropic effects of beta-blockers may increase myocardial perfusion.

The reduction of ventricular arrhythmias might be related to the stabilizing effect on the myocardial cell membrane.

\section{Future perspectives}

This thesis summarized that in STEMI patients undergoing primary $\mathrm{PCl}$, the use of early intravenous beta-blockers is safe but failed to reduce neither infarct size nor 1-year clinical outcomes. Given the apparent safety of intravenous metoprolol when administered in 
STEMI patients, and conflicting results on infarct size, future research should be performed to further address the potential effect of early (preferably in the ambulance) beta-blocker in STEMI patients undergoing PPCI.

For potential novel trials, some considerations have to be made:

- dose: a novel trial should be performed with a high-dose of $15 \mathrm{mg}$ metoprolol versus placebo and powered for clinical outcomes.

- timing of beta-blocker administration: a critical factor for future research should be the timing of the beta-blocker administration. Patients should receive iv beta-blocker long before reperfusion. A longer exposure to intravenous beta-blockade might be associated with smaller infarct size.

- end points: All the trials investigating the effect of beta-blocker administration in STEMI patients had infarct size (by MRI, TTE or enzymatic infarct size) as primary endpoint. Future larger studies should be performed with clinical outcomes as the primary endpoint and infarcts size as secondary endpoint.

- kind of beta-blockers: there are many $\beta-1$ selective beta-blockers available in the treatment of ischemic heart disease. The most studied and best available $\beta-1$ selective beta-blocker is Metoprolol. There are some small studies that suggest that the $\beta-1$ selective beta-blocker Carvedilol, has been associated with higher myocardial levels of the anti-inflammatory cytokine IL-10 and less myocardial oxidative stress, leukocytosis, and fibrosis, compared to Metoprolol. So, in the setting of an acute myocardial infarction, in which also arises an inflammation process in the infarct scar, it could be that Carvedilol has beneficial effects on inflammation and angiogenesis in this setting then Metoprolol. (1) But a big disadvantage of Carvedilol compared to Metoprolol is that it is not generally available for intravenous administration and not well studied in the setting of acute myocardial infarction.

Primary percutaneous intervention has considerably improved outcome of ST elevation myocardial infarction, shown in several randomized controlled trials and meta-analyses. (2-4) Results were impressive and showed a significant reduction in infarct size, improved left ventricular function and lower short and long-term mortality. Since then, many studies have tried to improve outcome and infarct size even further. Routine stenting reduced restenosis but did not improve infarct size. $(5,6)$ All kinds of pharmacologic therapies that were tried to reduce infarct size, ranging from anti-inflammatory (steroids) to agents targeted at improving metabolism (glucose-insulin-potassium) failed to improve outcome $(7,8)$. Glycoprotein 2 b3a blockers, especially when started early in the pre-hospital phase have been most successful in this regard (9). Also, neither stem-cell infusion in the infarct scar, nor erythropoietin (EPO) infusion reduced infarct size. $(10,11)$ 
We should not forget that the best way to reduce infarct size is still earlier reperfusion (by improvement of pre- and in-hospital logistics). Logistics are quite optimal in the Netherlands and this might in part be the reason why it is difficult to reduce infarct size more. (12) However, the beneficial safety profile, low costs and reduction of acute malignant arrhythmias of beta-blockers as summarized in this thesis, encourage the performance of additional larger trials in this field. 


\section{REFRENCES:}

1. DE Le, M Pascotto, H Leong-Poi, I Sari, A Micari, S Kaul. Anti-inflammatory and pro-angiogenic effects of beta blockers in a canine model of chronic ischemic cardiomyopathy: comparison between carvedilol and metoprolol. Basic Res Cardiol. 2013 Nov; 108(6):384

2. Zijlstra F, de Boer MJ, Hoorntje JCA, Reiffers S, Reiber J, Suryapranata H. A Comparison of Immediate Coronary Angioplasty with Intravenous Streptokinase in Acute Myocardial Infarction. N Engl J Med 1993;328:680-4.

3. Grines CL, Browne KF, Marco J, et al. A Comparison of Immediate Angioplasty with Thrombolytic Therapy for Acute Myocardial Infarction. N Engl J Med 1993 328:673-9.

4. Keeley EC, Boura JA, Grines CL. Primary angioplasty versus intravenous thrombolytic therapy for acute myocardial infarction: a quantitative review of 23 randomised trials. Lancet 2003 361:1320

5. Suryapranata H, De Luca G, van 't Hof AW, et al. Is routine stenting for acute myocardial infarction superior to balloon angioplasty? A randomised comparison in a large cohort of unselected patients. Heart 2005;91:641-5.

6. Grines CL, Cox DA, Stone GW, et al. Coronary angioplasty with or without stent implantation for acute myocardial infarction. Stent Primary Angioplasty in Myocardial Infarction Study Group. N Engl J Med 1999;341:1949-56

7. Niccoli G, Burzotta F, Galiuto L, Crea F. Myocardial no-reflow in humans. I Am Coll Cardiol. 2009; 54:281-92

8. van der Horst IC, Zijlstra F, van't Hof AW, et al. Glucose-insulin-potassium infusion in patients treated with primary angioplasty for acute myocardial infarction: the glucose-insulin-potassium study: a randomized trial. J Am Coll Cardiol. 2003;42:784-791

9. van 't Hof AW, Ten Berg J, Heestermans T, Dill T, Funck RC, van Werkum W, Dambrink JH, Suryapranata H, van Houwelingen G, Ottervanger JP, Stella P, Giannitsis E, Hamm C; Ongoing Tirofiban In Myocardial infarction Evaluation (On-TIME) 2 study group. Prehospital initiation of tirofiban in patients with ST-elevation myocardial infarction undergoing primary angioplasty (On-TIME 2): a multicentre, double-blind, randomised controlled trial. Lancet. 2008 Aug 16;372(9638):537-46.

10. A Hirsch, R Nijveldt, PA. van der Vleuten, JGP. Tijssen, WJ. van der Giessen, RA. Tio, J Waltenberger, JM. ten Berg, PA. Doevendans, WRM Aengevaeren, JJ Zwaginga, BJ Biemond, AC van Rossum, JJ Piek, F Zijlstra, on behalf of the HEBE Investigators. Intracoronary infusion of mononuclear cells from bone marrow or peripheral blood compared with standard therapy in patients after acute myocardial infarction treated by primary percutaneous coronary intervention: results of the randomized controlled HEBE trial. Eur Heart J. 2011;32:1736-1747

11. F Prunier, L Bière, M Gilard, J Boschat,F Mouquet, J-J Bauchart B Charbonnier, O Genée, P Guérin $K$ Warin-Fresse, E Durand, A Lafont, L Christiaens, W Abi-Khalil, S Delépine T Benard Furber. Single high-dose erythropoietin administration immediately after reperfusion in patients with ST-segment elevation myocardial infarction: results of the Erythropoietin in Myocardial Infarction Trial. Am Heart J 2012;163:200-207

12. AWJ van 't Hof, JP Ottervanger. Primary angioplasty for STEMI: hard to improve upon. Lancet. 2016 May 28;387(10034):2166-8 

Nederlandse samenvatting en discussie 



\section{SAMENVATTING EN CONCLUSIES.}

Dit proefschrift behandelt het effect van bètablokkers op de grootte van het hartinfarct, klinische eindpunten en veiligheidsprofiel, wanneer toegediend in een pre-hospitale setting vóór reperfusie therapie in het ST-elevatie myocardinfarct. De doelstellingen van dit proefschrift waren het onderzoeken van de invloed van intraveneuze toediening van bètablokkers vóór primaire $\mathrm{PCl}$ op de grootte van het hartinfarct, de klinische uitkomst op korte en lange termijn en het veiligheidsprofiel.

In hoofdstuk 1 wordt een korte inleiding gegeven over het onderwerp en de achtergrond van het proefschrift. De grootte van het myocardinfarct is een belangrijk bepalende factor voor morbiditeit en mortaliteit bij patiënten met een ST-segment myocardinfarct. De zuurstofbehoefte van het hart is hoger wanneer het hartritme toeneemt. Dus in theorie kan het verlagen van de zuurstofbehoefte door het verlagen van het hartritme in een ischemische situatie gunstig zijn. Bètablokkers zijn negatief inotrope medicijnen die mn de hartfrequentie remmen. Of de toediening van bètablokkers vóór reperfusie de grootte van het myocardinfarct vermindert, moet echter nog worden opgehelderd. Verder onderzoek naar het effect van vroege, preklinische toediening van bètablokkers op de omvang van het hartinfarct en de klinische uitkomst op lange termijn te beoordelen, is gewenst.

In hoofdstuk 2 wordt een overzicht gegeven van vroege behandeling met bètablokkers bij STEMI-patiënten in het trombolytische tijdperk. Ook worden de resultaten besproken van een multicenter, niet-gerandomiseerd, prospectief observationeel cohortonderzoek waarin STEMI-patiënten werden behandeld met directe of vertraagde toediening van oraal bisoprolol 2,5 mg. Deze studie is een van de eerste onderzoeken in het primaire PCl-tijdperk. Er werd een significante afname van mortaliteit aangetoond in de groep die direct met bisoprol werd behandeld ten opzichte van vertraagde behandeling (10,7\% vs. 19,2\%). Multivariabele regressieanalyse identificeerde directe bètablokker-therapie als beschermende behandeling voor mortaliteit. Het belang van deze studie ligt voornamelijk in de vergelijking van directe (<30 min.) versus vertraagde bètablokker toediening.

In hoofdstuk 3 worden de beweegredenen en het ontwerp van de Early-BAMI-studie beschreven. Deze studie onderzoekt het effect van intraveneuze toediening van metoprolol vóór primaire PCI in STEMI op de grootte van het hartinfarct, gemeten met MRI op 30 dagen. De studie werd ontworpen als een internationale, multicenter, dubbelblinde, placebogecontroleerde, gerandomiseerde studie, waarbij patiënten met symptomen en tekenen van STEMI werden getransporteerd naar het ziekenhuis voor primaire $\mathrm{PCl}$ en gerandomiseerd op een 1: 1-manier naar intraveneuze metoprolol ( 2 keer $5 \mathrm{mg}$ ) of placebo toediening. Bij opname zal een primaire $\mathrm{PCl}$ worden uitgevoerd volgens huidige standaard. Na primaire 
$\mathrm{PCI}$ volgt medicamenteuze behandeling volgens de huidige richtlijnen bij alle patiënten, inclusief het gebruik van orale bètablokkers. Het primaire eindpunt was de grootte van het myocardinfarct zoals beoordeeld met MRI op 30 dagen.

In hoofdstuk $\mathbf{4}$ wordt de associatie bestudeerd tussen chronisch bètablokker gebruik en hemodynamiek bij opname bij patiënten met STEMI, behandeld met primaire percutane coronaire interventie. In het bijzonder het potentiële risico van cardiogene shock (CS) en pre-shock bij patiënten met chronische bètablokkers behandeling. Een totaal van 4907 patienten met STEMI behandeld met PPCI, werden geïncludeerd in deze studie. 1148 patiënten $(23,3 \%)$ hadden een chronische behandeling met bètablokkers. CS werd waargenomen bij 264 patiënten (5,3\%). Pre-shock werd gedefinieerd als een Shock Index $\geq 0,7$ en werd waargenomen bij 1022 patiënten (20,8\%). Het risico op CS bij patiënten met chronische behandeling met bètablokkers was niet verhoogd. Chronische behandeling met bètablokkers was ook niet geassocieerd met een verhoogd risico op pre-shock (gecorrigeerde HR $0,86,95 \% \mathrm{Cl} 0,68-1,07, \mathrm{p}=0,19)$. Ook was er na propensity score gematchte analyse geen verhoogd risico op CS of pre-shock bij patiënten met chronische bètablokkerbehandeling (respectievelijk HR 0,97, 95\% Cl 0,61 - 1,51, p=0,88 en HR 0,82,95\% Cl 0,65 - 1,06, p $=0,12$ ). Deze bevindingen tonen dat chronische behandeling met bètablokkers niet geassocieerd is met een verhoogd risico op cardiogene shock of pre-shock bij STEMI-patiënten.

Hoofdstuk 5 presenteert de uitkomsten van de Early-BAMI studie, waarbij de invloed van intraveneuze toediening van metoprolol vóór primaire PCI in STEMI werd onderzocht op de grootte van het myocardinfarct, gemeten met MRI op 30 dagen en op klinische uitkomsten. In dit eerste dubbelblind, placebo-gecontroleerde internationale multicenter onderzoek, hebben we het effect van vroege i.v. bètablokkers vóór PPCI in een algemene STEMI-populatie $<12$ uur na aanvang van de symptomen, Killip I-II, zonder AV-blok onderzocht. Patiënten werden 1: 1 gerandomiseerd naar i.v. metoprolol (2x5 $\mathrm{mg}$ bolus) of gematcht placebo vóór primaire $\mathrm{PCl}$. Het primaire eindpunt was infarctgrootte, vastgesteld met magnetische resonantie beeldvorming (MRI) na 30 dagen. Secundaire eindpunten waren enzymatische infarct grootte en de incidentie van ventriculaire aritmieën. De veiligheidseindpunten omvatten symptomatische bradycardie, symptomatische hypotensie en cardiogene shock. Totaal werden 683 patiënten (gemiddelde leeftijd $62 \pm 12$ jaar, 75\% man) gerandomiseerd naar metoprolol $(n=336)$ of placebo $(n=346)$. MRI werd uitgevoerd bij 342 patiënten $(54,8 \%)$. Infarctgrootte (\% van LV) bij MRI verschilde niet tussen de metoprolol (15,3 $\pm 11,0 \%$ ) en placebogroep $(14,9 \pm 11,5 \% p=0,616)$. Voor enzymatische infarctgrootte verschilden de piek en oppervlakte onder de creatine kinase (CK) curve niet tussen beide groepen. Linker ventrikel ejectiefractie met MRI was $51,0 \% \pm 10,9 \%$ in de metoprololgroep en $51,6 \% \pm$ $10,8 \%$ in de placebogroep, $p=0,68$. De incidentie van maligne aritmieën was $3,6 \%$ in de metoprolol-groep versus $6,9 \%$ in placebo $p=0,05$. De incidentie van bijwerkingen was niet 
verschillend tussen groepen. Geconcludeerd werd dat in een algemene STEMI-populatie, vroege intraveneuze metoprolol vóór $\mathrm{PPCl}$, niet was geassocieerd met een reductie van de infarctgrootte. Metoprolol verminderde wel de incidentie van maligne aritmieën in de acute fase en was niet geassocieerd met een toename van bijwerkingen.

Hoofdstuk 6 beschrijft de lange (één jaars) klinische uitkomsten van het de Early-BAMI studie. De klinische uitkomsten na één jaar werd bepaald aan de hand van het MACEpercentage (major adverse cardiac event), gedefinieerd als hartdood, niet-fataal re-infarct of revascularisatie van het infarctvat. Eén jaar follow-up werd verkregen bij 629 patiënten (92\%). De gemiddelde follow-up tijd was $374+/-20$ dagen in de metoprolol groep versus $373+$ / - 23 dagen in de placebogroep. Incidentie van MACE na één jaar was 7,7\% in de metoprololgroep versus 7,3\% in de placebogroep. $P=0.835$. Er werd geconcludeerd dat in een algemene STEMI-populatie behandeld met PPCI, dat metoprolol i.v. voorafgaand aan transport naar het ziekenhuis vóór reperfusie niet resulteerde was in verlagen van klinische gebeurtenissen binnen één jaar.

Hoofdstuk 7 beschrijft een patiënt-gepoolde meta-analyse van gerandomiseerde klinische onderzoeken naar de evaluatie van de werkzaamheid en veiligheid van intraveneuze bètablokkers vóór primaire PCI voor STEMI. We zochten elektronische gegevensbestanden voor gerandomiseerde studies die vroege bètablokkergebruik vergeleken met routinematige zorg of placebo in patiënten met STEMI. We voerden een systeemevaluatie uit van de databases Medline, Web of Science en Cochrane Register of Controlled Trials tot oktober 2016 zonder taalbeperkingen. Om te voorkomen dat relevante studies ontbraken, werden referenties van de geïdentificeerde onderzoeken onderzocht. Studies opgenomen in de patiënt-gepoolde meta-analyse omvatten gerandomiseerde gecontroleerde studies die werden uitgevoerd in het huidige primaire PCI-gebied. We hebben de METOCARD-CNIC (effect van metoprolol bij cardioprotectie tijdens een acuut myocardinfarct), BEAT-AMI (BEtA-blokkertherapie bij acuut myocardinfarct), Early-BAMI (vroege bèta-blokkers toediening vóór primaire $\mathrm{PCI}$ bij patiënten met ST-elevatie myocardiaal infarct), de studie van Hanada et al. gerandomiseerde gecontroleerde studies geïncludeerd. De dataset omvatte 1150 patiënten, van wie 572 oorspronkelijk gerandomiseerd waren tot vroege intraveneuze bètablokkade en 528 tot placebo. De mediane tijd tot follow-up was 365 dagen. De gemiddelde leeftijd van de patiënten was 61 jaar en ongeveer driekwart was man. Meer dan 90\% van de patiënten onderging primaire PCI. Er waren geen significante verschillen in baseline kenmerken. Met betrekking tot cardiale bio-markers werd geen significant verschil waargenomen in piek-CK, CK-MB en/ of highsensitive troponine. De linker ventrikel ejectiefractie zes maanden na STEMI was significant hoger bij patiënten die werden behandeld met vroege intraveneuze bètablokkade $(52,7 \%$ versus $50,0 \%$ in de controlegroep, $P=0,03$ ). De belangrijkste klinische/ werkzaamheidsuitkomst dood of Ml trad op bij 4,6\% van de bètablokker-groep en 4,9\% van de controlegroep 
$(p=0,89)$. Er werd geconcludeerd dat bij STEMI-patiënten die primaire $\mathrm{PCI}$ ondergingen, het gebruik van vroege intraveneuze bètablokkers veilig was, met een mogelijke verbetering van de ejectiefractie van zes maanden. Er werd geen verschil waargenomen in klinische uitkomsten na 1 jaar.

\section{DISCUSSIE EN TOEKOMSTPERSPECTIEVEN}

\section{Discussie}

Omdat bij de meeste patiënten een snelle reperfusie van de geoccludeerde kransslagader bij een acuut myocardinfarct wordt verkregen, zijn verdere pogingen om het herstel van het myocardweefsel te verbeteren na een ischemische gebeurtenis gebaseerd op een beperking van de infarctgrootte.

Veel klinische onderzoeken hebben geprobeerd om de infarctgrootte te beperken met verschillende therapieën. Stamcelinjectie in het infarctweefsel, erytropoëtine (EPO)-toediening kort na een hartinfarct en een hoge dosis zuurstoftherapie hebben allemaal teleurstellende resultaten opgeleverd bij het verlagen van infarctgrootte.

Het potentieel van bètablokkers om myocardiale necrose te beperken, werd al lang geleden voorgesteld en de meeste data waren afkomstig uit het trombolytische tijdperk met tegenstrijdige resultaten. Een prospectieve gerandomiseerde studie (METOCARD-CNIC) in het huidige pPCI-tijdperk toonde een afname in infarctgrootte en toename in LVEF in STEMIpatiënten met een voorwand infarct.

In dit proefschrift laten de resultaten van zowel de Early-BAMI studie als van een meta-analyse echter geen voordeel zien op infarctgrootte of LVEF met vroege bètablokker toediening aan STEMI-patiënten.

Deze tegenstrijdige resultaten kunnen worden verklaard door de volgende factoren. Ten eerste was de infarctgrootte kleiner in de Early-BAMI-studie, waardoor het minder waarschijnlijk was dat vroege bètablokkade de infarctgrootte zou verminderen. Ten tweede was de dosis metoprolol die werd gebruikt in METOCARD-CNIC-studie 15 mg, terwijl 10 mg werd gebruikt in de Early-BAMI-studie. Een derde verklaring kan gerelateerd zijn aan de timing van de toediening van metoprolol. In een subanalyse van METOCARD-CNIC was langere blootstelling aan intraveneuze bètablokkade geassocieerd met een kleinere infarctgrootte. In Early-BAMI werd de tweede bolus vlak voor PCI toegediend. 


\section{Pathofysiologische effecten van bètablokkers}

Een mogelijk gunstig effect van bètablokkers kan worden verklaard door verschillende mechanismen. Over het algemeen veroorzaakt blokkering van bèta-1-receptoren een verlaging van zowel de hartfrequentie als de contractiliteit van het myocard, met een lagere systemische bloeddruk. Dit resulteert in een verminderde myocardiale werkbelasting en zuurstofbehoefte. Bovendien kan verlenging van de diastolische fase veroorzaakt door de chronotrope effecten van bètablokkers de hartspierperfusie verhogen. De vermindering van ventriculaire aritmieën kan verband houden met het stabiliserende effect op het myocardiale celmembraan.

\section{Toekomstperspectieven}

Dit proefschrift vat samen dat bij STEMI-patiënten die een primaire $\mathrm{PCI}$ ondergaan, het gebruik van vroege intraveneuze bètablokkers veilig is, maar niet in staat is om de infarctgrootte noch klinische eindpunten op 1 jaar te verminderen. Gezien de veiligheid van intraveneus metoprolol bij toediening aan STEMI-patiënten en tegenstrijdige resultaten op infarctgrootte, moet meer toekomstig onderzoek worden uitgevoerd om het potentiële effect van vroege (bij voorkeur in de ambulance) bètablokkers bij STEMI-patiënten die een PPCI ondergaan verder aanpakken.

Voor deze potentiële nieuwe studies moeten echter enkele overwegingen worden gemaakt:

- dosis: een nieuwe studie moet worden uitgevoerd met een hoge dosis van 15 mg metoprolol versus placebo en wordt gebruikt op klinische uitkomsten.

- timing van de toediening van bètablokkers: een kritieke factor voor toekomstig onderzoek moet de timing zijn van de toediening van bètablokkers. Patiënten dienen lang vóór de reperfusie een iv bètablokker te krijgen. Een langere blootstelling aan intraveneuze bètablokkade kan in verband worden gebracht met een kleinere infarctgrootte.

- Eindpunten: alle onderzoeken naar het effect van toediening van bètablokkers bij STEMIpatiënten hadden een infarctgrootte (door MRI, TTE of enzymatische infarctgrootte) als primair eindpunt. Toekomstige grotere onderzoeken moeten worden uitgevoerd met klinische uitkomsten als het primaire eindpunt en de infarctgrootte als secundair eindpunt.

- soort van bètablokkers: er zijn veel bèta 1-selectieve bètablokkers beschikbaar voor de behandeling van ischemische hartaandoeningen. De meest bestudeerde en best beschikbare bèta 1 selectieve bètablokker is Metoprolol. Er zijn enkele kleine studies die suggereren dat de niet selectieve bètablokker Carvedilol in verband is gebracht met hogere myocardiale spiegels van het ontstekingsremmende cytokine IL-10 en minder myocardiale oxidatieve stress, leukocytose en fibrose vergeleken met Metoprolol. Dus in de setting van een acuut myocardiaal infarct, waarin ook een ontstekingsproces in het litteken van het infarct ontstaat, kan het zijn dat Carvedilol gunstigere effecten heeft op ontsteking en angiogenese in deze setting dan Metoprolol. (1) Maar een groot nadeel 
van Carvedilol vergeleken met Metoprolol is dat het niet algemeen beschikbaar is voor intraveneuze toediening en niet goed in de setting van een acuut myocardiaal infarct.

Primaire percutane interventie heeft de uitkomst van een ST-elevatie-myocardinfarct aanzienlijk verbeterd, weergegeven in verschillende gerandomiseerde gecontroleerde studies en meta-analyses. (2-4) De resultaten waren indrukwekkend en toonden een significante afname van de infarctgrootte, verbeterde linkerventrikelfunctie en lagere mortaliteit op korte en lange termijn. Sindsdien hebben veel studies geprobeerd de uitkomst en infarctgrootte nog verder te verbeteren. Routinematig stenting verminderde de kans op restenose, maar de infarctgrootte niet. $(5,6)$ Allerlei farmacologische therapieën die werden geprobeerd om de grootte van het infarct te verminderen, variërend van ontstekingsremmende (steroïden) tot middelen gericht op het verbeteren van het metabolisme (glucose-insuline-kalium) konden de uitkomst niet verbeteren $(7,8)$. Glycoproteïne 2b3a-blokkers, vooral wanneer ze in het begin van de pre-hospitaalfase zijn gestart, zijn in dit opzicht het meest succesvol geweest (9). Ook infusie van stamcellen in het infarctlitteken of de infusie van erytropoëtine (EPO) verminderde de infarctgrootte niet. $(10,11)$

We mogen niet vergeten dat de beste manier om de omvang van het infarct te verkleinen nog steeds vroege reperfusie is (door verbetering van de logistiek vóór en in het ziekenhuis). Logistiek is redelijk optimaal in Nederland en dit kan deels de reden zijn waarom het moeilijk is om de infarctgrootte meer te verminderen. (12)

Het gunstige veiligheidsprofiel, de lage kosten en het verminderen van acute maligne aritmieën door bètablokkers zoals samengevat in dit proefschrift, moedigen echter het uitvoeren van aanvullende, grotere trials op dit gebied aan. 



\section{LIST OF PUBLICATIONS}

1. Roolvink V, Luijten HE, Brouwer MA, Verheugt FWA. Optimal discriminative value of troponin-I for 6-month cardiac event rate in the evaluation for suspected acute coronary syndromes. J Am Coll Cardiol. 2001;37(supp A): 316A.

2. Roolvink V, Meursing BTJ, Tummers JKJM, Haarbrink RH, Ernst JMPG. Arteriovenous fistula after intervertebral disk surgery L4-L5. Neth Heart J 2004;12:295-298

3. Roolvink V, van Dijk A, Verheugt FWA. Massive Left Ventricular Septum Aneurysm with Rupture to the Right Ventricle Imaged by Three-Dimensional Transthoracic Echocardiography. J Am Soc Echocardiogr 2008: 21(2):187

4. Rasoul S, Roolvink V, Ottervanger JP, van 't Hof AWJ. Myocardial infarction without ECG abnormalities: consider occlusion of the circumflex coronary artery. Ned Tijdschr Geneeskd. 2012;156(13):A4158

5. Rasoul S, Roolvink V, Ottervanger JP, Gosselink ATM, Dambrink JHE, de Boer MJ, Hoorntje JCA, Suryapranata $H$, van 't Hof AWJ. Angiography guided therapy in an all comer acute coronary syndrome patient population. Int J Cardiol. 2013;168(5):4900-2

6. Roolvink V, van 't Hof AJW, van der Horst ICC. The sooner, the better: early beta-blocker administration in patients with ST-elevation myocardial infarction. Crit Care Med. 2013 ;41(6): 1566-8.

7. Roolvink V, Rasoul S, Ottervanger JP, Dambrink JHE, Gosselink ATM, Hoorntje JCA, Hermanides RS, Suryapranata $H$, van 't Hof AWJ. Circumflex artery related myocardial infarction: less reperfusion therapy and large infarct size. Int J Cardiol. 2013;168(2):1624-6.

8. Kilic S, Ottervanger JP, Dambrink JHE, Hoorntje JCA, Roolvink V, Gosselink ATM, Suryapranata $\mathrm{H}$, van 't Hof AWJ. The effect of thrombus aspiration during primary percutaneous coronary intervention on clinical outcome in daily clinical practice. Thromb Haemost. 2014 Jan;111(1):165-71

9. Roolvink V, Rasoul S, Ottervanger JP, Dambrink JHE, Lipsic E, van der Horst ICC, de Smet B, Kedhi E, Gosselink ATM, Piek JJ, Sanchez-Brunete V, Ibanez B, Fuster V, van't Hof AWJ. Rationale and Design of a Double-blind, Multicenter, Randomized, Placebo controlled Clinical trial of Early Administration of Intravenous Beta-blockers in Patients with STelevation Myocardial Infarction before Primary PCI. : EARLY Beta-blocker Administration before primary PCI in patients with ST-elevation Myocardial Infarction (EARLY-BAMI) trial. Am Heart J. 2014;168(5):661-6.

10. Remkes WS, Somi S, Roolvink V, Rasoul S, Ottervanger JP, Gosselink ATM, Hoorntje JCA, Dambrink JHE, de Boer MJ, Suryapranata $H$, van 't Hof AWJ. Direct drug-eluting stenting to reduce stent restenosis: a randomized comparison of direct stent implantation to conventional stenting with pre-dilation or provisional stenting in elective $\mathrm{PCl}$ patients. Zwolle Acute Myocardial Infarction Study Group. JACC Cardiovasc Interv. 2014 ;7(7):751-8 
11. Roolvink V, MD, Hemradj VV, Ottervanger JP, van 't Hof AWJ, Dambrink JHE, Gosselink ATM, Kedhi E, Suryapranata H. Effects of chronic beta-blocker treatment on admission haemodynamics in STEMI patients treated with Primary Angioplasty. European Heart Journal: Acute Cardiovascular Care. 2017. Accepted.

12. Roolvink V, Ibanez B, Ottervanger JP, Pizarro G, van Royen N, Mateos A, Dambrink JHE, Escalera N, Lipsic E, Albarran A, Fernández-Ortiz A, Fernández-Avilés F, Goicolea J, Botas J, Remkes W, Hernandez-Jaras V, Kedhi E, Zamorano JL, Navarro F, Alfonso F, GarcíaLledó A, Alonso J, van Leeuwen M, Nijveldt R, Postma S, Kolkman E, Gosselink ATM, de Smet B, Rasoul S, Piek JJ, Fuster V, van't Hof. Early Intravenous Beta-Blockers in Patients With ST-Segment Elevation Myocardial Infarction Before Primary Percutaneous Coronary Intervention. EARLY-BAMI Investigators. J Am Coll Cardiol. 2016 Jun 14;67(23):2705-15

13. Schellings DAAM, Adiyaman A, Dambrink JHE, Gosselink ATM, Kedhi E, Roolvink V, Ottervanger JP, van 't Hof AWJ. Predictive value of NT-proBNP for 30-day mortality in patients with non-ST-elevation acute coronary syndromes: a comparison with the GRACE and TIMI risk scores. Vasc Health Risk Manag 2016;12:471-476

14. Kennedy MW, Kaplan E, Hermanides RS, Fabris E, Hemradj V, Koopmans PC, Dambrink JHE, Gosselink ATM, van 't Hof AWJ, Ottervanger JP, Roolvink V, Remkes WS, van der Sluis A, Suryapranata $H$, Kedhi E. Clinical outcomes of deferred revascularisation using fractional flow reserve in patients with and without diabetes mellitus. Cardiovasc Diabetol 2016;15:100

15. Kennedy MW, Hermanides RS, Kaplan E, Hemradj V, Fabris E, Koopmans PC, Dambrink JHE, Gosselink ATM van 't Hof AWJ, Ottervanger JP, Roolvink V, Remkes WS, van der Sluis A, Suryapranata $H$, Kedhi E. Fractional flow reserve-guided deferred versus complete revascularization in patients with diabetes mellitus. Am J Cardiol 2016; 118:1293-1299

16. Fabris E, Kennedy MW, Di Mario C, Sinagra G, Roolvink V, Ottervanger JP, van 't Hof AWJ, Kedhi E. Guide extension, unmissable tool in the armamentarium of modern interventional cardiology. A comprehensive review. Int J Cardiol 2016;222:141-147

17. Kilic S, Hermanides RS, Ottervanger JP, Kolkman E, Dambrink JH, Roolvink V, Gosselink AT, Kedhi $E$, van 't Hof AWJ. Effects of radial versus femoral artery access in patients with acute myocardial infarction: A large centre prospective registry. Neth Heart J. 2017 Jan;25(1):33-39

18. Roolvink V, Ottervanger JP, Ibanez, Dambrink JHE, Gosselink ATM, Kedhi E, van Royen N, Lipsic E, Remkes W, Piek JJ, Fuster V, van 't Hof AWJ. One year clinical outcome of early administration of intravenous beta-blockers in patients with ST-segment elevation myocardial infarction before primary percutaneous coronary intervention. One year results from the EARLY-BAMI trial. Eurointervention 2017, Epub, ahead of print.

19. Damman P, Roolvink V, Hoedemaker NPG, de Winter RJ, van Royen N, Fuster V, García-Ruiz JM, Er F, Gassanov N, Hanada K, Okumura K, Ibáñez B, van 't Hof AWJ. Early intravenous beta-blockers in patients undergoing primary percutaneous coronary intervention for STsegment elevation myocardial infarction. A patient-pooled meta-analysis of randomized clinical trials. Eur Heart J, 2017, submitted. 



\section{DANKWOORD}

Met het schrijven van dit dankwoord leg ik de laatste hand aan mijn proefschrift. Trots kijk ik terug naar de afgelopen jaren vol leermomenten, uitdagingen, de nodige deadlines, maar ook vele hoogtepunten zoals de late-breaking presentatie op de ACC van de Early-BAMI studie resultaten in maart 2016 in Chicago.

In 2008 werd het idee geboren van de Early-BAMI studie door mijn (toenmalige) collega's Saman Rasoul, Jan Paul Ottervanger en Arnoud van 't Hof. In 2010 begon voor mij het onderzoekavontuur, nadat jullie me dit project hadden toevertrouwd. Gaandeweg het promotietraject groeide de studie met de hulp van velen uit tot een internationale multi-center studie. Want het uitvoeren van een onderzoek en promoveren doe je nooit alleen. Vele collega's hebben de afgelopen jaren een bijdrage geleverd aan de totstandkoming van dit proefschrift. Ik wil iedereen die me daarbij heeft geholpen hartelijk danken.

Klinisch onderzoek is natuurlijk niet mogelijk zonder patiënten. Zonder hun medewerking had dit onderzoek nooit gestalte gekregen.

Graag wil ik een aantal mensen in het bijzonder bedanken

Als eerste mijn promotor prof. dr. A.W.J. van 't Hof. Beste Arnoud, tijdens en na mijn fellowship interventiecardiologie heb je mij (naast velen) enthousiast gemaakt voor het verrichten van wetenschappelijk onderzoek. Ik ben je tot op de dag van vandaag dankbaar dat je me het Early-BAMI project destijds hebt toevertrouwd. Je wetenschappelijke inspiratie en vastberadenheid werkt zeer motiverend. Dat hieruit voor jou een leerstoel interventie cardiologie is voortgekomen, was meer een kwestie van tijd. Voor de wijze waarop je mij hebt begeleid tijdens mijn promotie en voor de vele jaren van plezierige samenwerking zeg ik oprecht Dank!

Geachte dr. J.P. Ottervanger, beste Jan Paul, wat ben ik ontzettend blij en vereerd om jou als copromotor te hebben. Je hebt inmiddels ontelbaar veel promoties begeleid. Met jouw schijnbaar moeiteloze, heldere en scherpe schrijfstijl ben je een voorbeeld voor velen. Ongekend hoeveel proefschriften dankzij jouw begeleiding de eindstreep hebben gehaald. Dank voor de vele uren artikelen "bijschaven", statistieken analyseren en daarnaast de grote lijnen in het oog houden. En als ik het soms even niet meer duidelijk zag zitten, wist je me altijd weer een positief zetje te geven. Ik verheug me op nog vele jaren samenwerking met je. 
De leden van de beoordelingscommissie, prof. dr. H.P. Brunner La Rocca, voorzitter, prof. dr. N. van Royen, prof. dr. F. Zijlstra en prof. dr. J.C.A. Hoorntje wil ik hartelijk danken voor het beoordelen van mijn manuscript.

Raymond van der Jagt, paranimf en beste vriend. Ray, vele uren in de kroeg, sportschool en op de fiets hebben we door de jaren heen samen gedeeld. Altijd heb je me van de zijlijn aangemoedigd en was je een luisterend oor. Op ons huwelijk was je mijn getuige, en ook nu ben ik vereerd dat je me wil bijstaan als paranimf!

Maarten van Leeuwen, nog voordat je onze Zwolse maatschap kwam versterken, coördineerde je reeds de patiënten inclusie in de VU (van de Early-BAMI studie). Wie had toen kunnen bedenken dat we nu een CTO-team vormen? Je gedrevenheid en enthausiasme werken erg aanstekelijk. Mede gezien je kennis rond het onderwerp, ben ik blij dat je me als paranimf wil bijstaan.

Sonja Postma, beste Sonja zonder jou als projectleider van de Early-BAMI studie bij Diagram was dit boekje mogelijk nooit tot stand gekomen. Jouw begeleiding en coördinatie van de studie was voortreffelijk. Aan onze studie bezoekjes naar het CNIC in Madrid heb ik goede herinneringen.

Verder wil ik alle andere medewerkers van Diagram bedanken voor de CRF monitoring, data-entry, etc.. In het bijzonder Jaap Klein, voor je coördinatie, Evelien Kolkman voor je statistiek analyses en Anna Castella voor je communicatie en begeleiding met de studie sites in Madrid.

I would like to thank Borja Ibanez, head of research of the CNIC in Madrid, and author of the METOCARD -trial. Thank you for joining us in the Early-BAMI trial, your critical input and support. Tanks for the core-lab analysis of all the cardiac MRI's. I enjoyed the collaboration and hope we will continue working together in future projects. The MOVE-ON trial has to start!

Prof. dr. N. van Royen en prof. dr. J.J. Piek, beste Niels en Jan, dank voor de deelname van de VU en het AMC aan de Early-BAMI studie.

De vakgroep Cardiologie, maatschap, SIDS en fellow's. Beste maten Ed, Marcel, Arif, Jan Paul, Peter Paul, Elvin, Jan-Henk, Anand, Jorik, Jaap Jan, Ahmet en Maarten. De SIDS Marleen, Marc, Abdul, Wouter, Irlando, Shu en alle fellows met name Rik en Veemal. Allen bedankt voor jullie vertrouwen, steun en geduld. Velen van jullie hebben bijgedragen aan de publicaties in dit proefschrift, dank! Dagelijks geniet ik van de fijne samenwerking op de Zwolse werkvloer van het Hartcentrum! 
Vera Derks, beste Vera, enorm bedankt voor alle ondersteuning in het corrigeren en insturen van alle manuscripten.

Alle medewerkers op de HCK, dagelijks trekken we ons interventie strijdpak aan tegen hart- en vaatziekten. Dank voor jullie medewerking en registraties tijdens de Early-BAMI studie. Mede door jullie inzet en ondersteuning behoort Zwolle al jaren tot één van de top interventie en ritme centra van het land.

Alle arts-assistenten wil ik bedanken voor de goede, gedreven en gezellige dagelijkse samenwerking. Mede dankzij jullie worden er al jaren vele patiënten geïncludeerd in vele studies.

Alle ambulance medewerkers van de RAV IJssellanden, UMCG en Witte Kruis en van SUMMA-112 in Madrid, dank voor het includeren van alle patiënten! Met name Rudolf Tolsma, dank voor je organisatie en coördinatie rondom de Early-BAMI studie.

Niet te vergeten de secretaresses van het gehele Hartcentrum. Jullie zijn een belangrijke ondersteuning en zorgen voor patiënt-vriendelijkheid, goede planning en gezellige sfeer bij het Hartcentrum.

Mijn ouders, Lieve Pap en Mam, dank dat jullie me altijd de mogelijkheid hebben gegeven om te komen waar ik nu ben. Dank voor jullie liefde en vertrouwen in de keuzes die ik tot nu toe heb gemaakt.

Mijn broer, beste Arnold, we zien elkaar niet heel frequent, maar weten elkaar altijd te vinden en te steunen bij wat er op ons pad komt. Dank daarvoor.

Mijn schoonouders, lieve Adri en Bernard, vanaf het begin dat jullie in mijn leven kwamen, was het een heerlijk warm bad. Jullie zijn altijd betrokken en geïnteresseerd. Ontelbaar vaak staan jullie vol liefde voor ons en vooral voor de meiden klaar. Ik kan jullie niet genoeg bedanken.

Lieve Anouk en Lieke, jullie zijn mijn kostbaarste bezit. Wat ben ik trots op jullie! Papa met een drukke baan als dokter betekend dat ik minder vaak thuis ben dan jullie en ik zouden willen. Maar samen genieten we van elkaar en vormen we een hecht en warm gezin. Niks haalt het bij een dikke knuffel van jullie! Jullie kunnen me een spiegel voorhouden als ik ernaast zit, en me blij maken met een glimlach. Trots ben ik op dit boekje, maar geen enkel boekje kan beschrijven hoe trots ik ben om jullie papa te zijn! 
Lieve Sigrid, al sinds 2001 mijn levensmaatje en mijn allerliefste. Je weet als geen ander hoeveel tijd en energie dit proefschrift heeft gekost, en zonder jou was het me nooit gelukt. De dankbaarheid die ik hiervoor heb is enorm en moeilijk in woorden uit te drukken! Je hebt me altijd in m'n werk ondersteund en opgebeurd als het even tegen zat. Je bent mooi, oprecht, eerlijk, vult me aan, daagt me uit en geeft eerlijke feedback. Ik bewonder de manier waarop je in het leven staat en ben blij daar deel van uit te maken. We hebben de wereld 2 fantastische meiden gegeven. Samen vormen we een warm thuis, genieten van het leven en maken mooie reizen en herinneringen.

Ik hou van je! 




\section{CURICULUM VITAE}

Vincent Roolvink werd geboren op 9 januari 1977 te Enschede. Na het behalen van zijn VWO-diploma op het Kottenpark college te Enschede in 1995, studeerde hij Geneeskunde aan de Radboud Universiteit in Nijmegen (1995-2001). Zijn wetenschappelijk stage deed hij bij de cardiologie in het Radboud UMC alwaar hij onderzoek deed naar de voorspellende waarde van troponine I bij patiënten die zich presenteerden op de eerste hulp. Na afronding van zijn keuze co-schap cardiologie in het Radboud UMC te Nijmegen, behaalde hij in februari 2002 zijn arts-examen, waarna hij gedurende 6 maanden heeft gewerkt als artsassistent cardiologie niet in opleiding in het Canisius Wilhelmina ziekenhuis in Nijmegen. Van 1 augustus 2002 tot 1 augustus 2008 heeft hij gewerkt als cardioloog in opleiding aan het Radboud UMC. Na het afronden van zijn opleiding tot cardioloog heeft hij vanaf 1 augustus 2008 tot 1 augustus 2010 gewerkt als fellow interventie cardioloog in de Isala klinieken te Zwolle. Na zijn fellowship interventie cardiologie is hij werkzaam gebleven als interventie cardioloog in het Isala ziekenhuis te Zwolle en is daar op 1 april 2016 toegetreden tot de maatschap cardiologie. Naast zijn werkzaamheden als interventie cardioloog in Zwolle is hij in 2010 gestart met wetenschappelijk onderzoek met als belangrijk onderwerp de EarlyBAMI-studie, wat uiteindelijk geresulteerd heeft in dit proefschrift. Verder valt te vermelden dat hij incidenteel halve en hele marathons loopt en amateur wielrenner, mountainbiker en windsurfer is. Vincent is getrouwd met Sigrid Brosi, ze hebben samen 2 dochters, Anouk en Lieke. 